Historic, archived document

Do not assume content reflects current scientific knowledge, policies, or practices. 
H. G. M. Darrow, Queloulture \& Pomology. Bureau of plant Industry. 


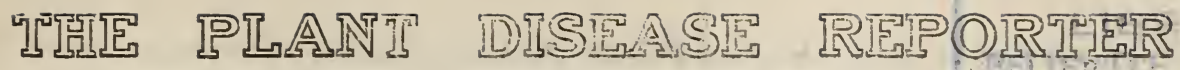

Issued By

mithe Plan IDisease Surpey

Supplement 37

Diseases of Forest and Shade Trees, Ornamental and Miscellaneous Plants in the United States in 1923

March 30, 1925

BUREAU OF PLANT INDUSTRY

UNITED STATES DEPARTMENT OF AGRICULTURE 
List of collaborators of the Plant Disease Survey who have made the principal contribution to the 1923 annual summary.

It should be understood that many other collaborators and pathologists have assisted in gathering data within the States but the following list includes those who actually furnished state reports to the washingtor office.

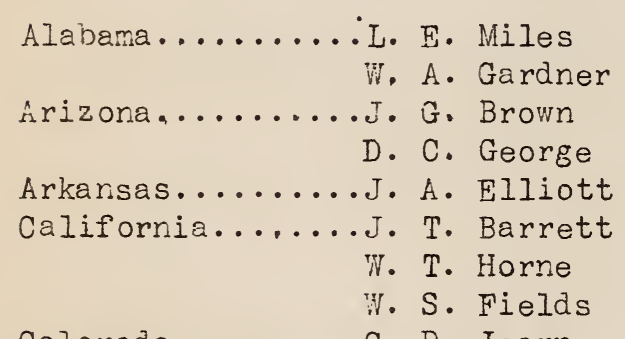

Colorado.......... D. Learn

Ellsworth Bethel

Connecticut.......G. P. Clinton

E. M. Stoddard

Delaware.........J. F. Adamis

Florida........... F. Burger

G. F. Weber

Georgia..........T. H. McHattor

Idaho............. W. Hurgerford

Henry Schmitz

Illinois.........H. W. Anders on

L, R. Tehon

Indiana............ G. Gardner

Iowa............. I. E. Melnus

H. S. Coriard

ansas........... E. E. Melchers

R. F. Wite

E. A. Stokdyk

Kentucky........... D. Valleau

Louisiana.......... W. Edgerton

Maine............. J. Morse

Maryland.......... E. Temple

R. A. Jehle

Massachusetts.....A. V. Osmun

W. H. Davis

P. J. Anderson

Michigan........... I. Coons

Minnesota...........sect. PI. Path.

Mississippi.......D. C. Neal

H. D. Barker

Missouri........... C. Burrill

W. E. Maneval

Montana.............. Jennison

D. B. Swingle

W. N. Christopher
Nebraska........., R. W. Goss

Nevada............ W. Iantz

New Hampshire....... Butler

New Jersey...........sect. Pl. Pat..

New Mexico........... F. Crawford

New York.......... Charles Chupp

I. M. Massey

R. S. Kirby

North Carolina....... C. Foster

North Dakota......... L. Bolley

Wanda Weinger

Ohio.............. D. Selby

H. C. Young

R. C. Thomas

Freda Detmers

Oklahoma..........Robert Stratton

Oregon............... P. Barss

S. M. Zeller

C. E. Owens

Pennsy Ivania........ . R. Orton

W. A. McCubbin

H. W. Thurston

L. O. Overholtz

Rhode Island.......H. W. Browning

W. A. Snell

South Carolina.....C. A. Iudwig

South Dakota.......... J. Petry

A. T. Evans

Tennessee.......... I. R. Hesler

Texas............... J. Taubenhaus

Utah............. I. Richards

Vermont............ F. Lutman

Virginia............ D. Fromme

Washington........... D. Heald

B. F. Dana

rthur Frank

West Virginia........ J. Giddings

E. C. Sherwood

inthony Berg

Wisconsin.......R. $\Gamma_{i}$. Vaughan

Wyorning............. Nen Nelson 
DISEASES OF FORFST AND SHADE TREES, ORNANENTAL AND HISCELLANOUS PLANTS

\section{THE UNITED STATES IN 1923}

Plant Disease Reporter Supplemont 37

March 30,1925

Prepared by

G. Hamilton-Martin

\section{CONTENTS}

Diseases of forest, shade and ornamenta.1 trees....350 Conifers..................... 350 Hardwoods...........359
Diseases of ornamental shrubs and plants................... 384

Diseases of miscellaneous piants.................417

\section{Foreword}

This summary of the discases of forest and shade trees, ornamental and miscellaneous plants in the United States in 1923 follows the same general pien as those of the preceding years. The sources upon which the information is based are as follows: (1) collaborators, (2) specialists in the Office of Forest Pathology, (3) articles in botanical journals, and (4) special reporters.

Many reports of new occurrences were received for 1923 both for states and for the United States. In the accompanying summary these first occurrences have been noted by symbils before each individual report. New York, Mississippi, Minnesota, Florida and Connecticut contributed the largest number of first reports. Many occurrences are given which have been obtained from literature, from the herbarium of Pathological Collections, or from past records of the Plant Disease Survey. Quite a number of diseases have been omitted due to their unimportance or to the fact that they have been reported in other years. 'It is not the object of this summary to enumerate all oi the discases that have been reported during the year, but to give facts corcerning only some of tho more important ones. Owing to the nature of the data it is presented herewith in list form

Where specimens are not indicated the report is based on the authority of the person cited. The date given is that of its earliest reported appearance in 1923. Reports from British Columbia are given on account of the probable occurrence of the disease being also in Washington and Idaho.

The following symbols are used: * indicates a specim $n$ in pathological Collections; + preceding disease indicates the first report of the disease to the Plant Disease Survey; + precoding state indicates the first report from the state to the Plunt Disease Survey.

References have been given and in some instances brief abstracts made of recent sirticles which may be of service to those who do not have access to all the botanicel journals. A list of collaborators is given on the opposite pago. The names of the special reporters are as follows: 
Boyce, J. S.

Dewey, L. H.

Foster, A. C.

Gravatt, A. E.

Gravatt, A. H.

Graviat, G. F.

Graves, Arthur

Hahn, G. G.
Harter, Lt L. Haskell, R. J. Jenkins, Ainna $\mathrm{F}$. Kinskern, E. A. Martin, J. F. McComick, F. A. McCulloch, I. Ninman, $J \cdot H$.
Posey, G. B. Rhodes, A. I. Strayer, F. R. Tisdale, W. B. Weimer, W. L. Weir, J. R. Zappe, M. P.

\section{DISEASES OF CONIFERS}

CEDAR, WHITE (Chamaecyparis thyoides)

Rust caused by Gymnosporangium ellisii (Berk.) Farl.

Connecticut - fruiting abundantly on the witches brooms, first report made in 1922, Bethany, New Haven County. (Clinton)

Prior reports: Alabama, Connecticut, *Delaware, Florida, *Massachusetts, *New Jersey, *Pennsylvania and Rhode Island.

CEDAR, CALIFORNIA INCENSE (Libocedrus decurrens)

Rust caused by Gymnosporangium blasdaleanum (D. \& H.) Kern

Oreg on - locally severe; Rujada, Lane County, June 17. (Boyce)

Prior reports: *Oregon and *California.

CEDAR (Juniperus procumbens and J. sabina)

Phomops is juniperovora Hahn; Pennsylvania - (A. E. Gravatt)

CEDAR, COLORADO JUNIPER (Juniperus scopulorum)

Rust caused by Gymnosporangium globosum Farl.

+Colorado - (Learn). Prior report: *North Dakota. +Phomops is juniperovora Hahn; Illinois - (A. E. Gravatt)

CEDAR, RED (Juriperus virginiana)

Rust caused by Gymnosporangium globosum Farl.

*New York - common in Hudson Valley, May 15. (Chupp)

Iowa - an unusually large amount of sporulation occurred. (Melhus)

Prior reports: ilabama, Connecticut, *Indiana, Iowa, Kansas, *Massachusetts, Minnesota, *Mississippi, *Missouri, New

York, North Dakota, Pennsylvania, *South Carolina, West Virginia and Wisconsin.

Rust caused by Gymnosporangium juniperi-virginianae Schw.

Reportod from *New York, Connecticut, *New Jersey, South Carolina and Ohio.

Prior reports: *Alabama, Delaware, Georgia, *Indiana, *Iowa, *Kansas, Louisiana, *Maryland, *Massachusetts, Minnesota, Mississippi, *Miss uri, Montana, *Nebraska, *New Jersey, North Dakota, Pennsylvania, Suuth Fakota, *Mexas, *Virginia, West Virginia and Wisconsin.

Phomopsis juniperovora Hahn; Pennsylvania, Illinois - (A. E. Gravatt)

Prior reports:Illinois, Iowa, Kansas, Minnesota, Nebraska, New York, Ohio, and *Pennsylvania.

CEDAR (Puniperus spp.)

Phomopsis juniperovora Hahn; Missouri - in a nursery; new for state. (Maneva 1) 
New York - reported on Salix nigra; Onondago County, September 15. (Chupp)

Rust caused by Melampsora. bigelowii Thuem.

+New York - reported on +Salix discolor, +S. lucida and +S. amygdaloides, Tompkins County, September 2. (Chupp)

Minnesota - Itasca County. (Sect. Pl. Path.)

Oregon - abundant; Homestead Inn; Hood River County. (Boyce)

Prior reports: *Colorado, Connecticut, Idaho, *Illinois, *Indiana,

Iowa, *Kansas, *Michigan, Minnesota, *Montana, *Oregon,

*Ponnsylvania, *Tennessee, Texas, *Virginia, *Washington,

West Virginia and * Wyoming.

Rust caused by Melampsora larici-capraearum Kleb. (M. Salicis caprae wint.)

+Okluhoma - Payne County, October 25. (Stratton)

Prior reports: Minnesota, Montana and Ohio.

Powdery mildew caused by Uncinula 'salicis (DC.) Wint.

New York - probably statewide; Tompkins County, August 18. (Chupp)

Iowa - (Melhus)

Oregon - abundant and sometimes caused premature leaf fall; Port-

land, MuItnomah County, October 28. (Boyce). Prior reports:

Connecticut, *Illinois, *Indiana, *Iowa, *Maine, Máryland,

Massachusetts, *Michigan, *Minnesota, *Miss issippi, *Montana,

*New Hampshire, *New York, *North Dakota, *Ohio, *Oregon,

*Vermont, *Virginia, Washington and *Wisconsin.

Canker - cause uridetermined

Connecticut - similar to Furopean canker but microscopical examination failed to verify the cause. (clinton)

Flyspeck - $0 \cdot 1$ se undetermined

New York - reyorted on Salix discolor; Onondago County, September 10. (Chupp)

\section{WOOD DESTROYING FUINGI}

Wood rot caused by Polyporus schweinitzii Fr.

Minnesota - saprophytic on trunks of picea mariana and pinus resinosa and on the roots of pinus divaricata. (Sect. PI. Path.)

Wood rot caused by Polyporus ancops $\mathrm{Pk}$.

Minnesota - very common wood rot of conifers. (Scct. Pl. Path.)

Rot caused by Poria incrassata (B. \& C.) Burt.

Florida-during the past year the Plant pathologist was called to St. Petersburg where a lumber company reported the loss of thousands of dollars worth of lumber because of a fungous organism which causes rot to timber. The fungus Poria incrassatal was found very prevalent in ail parts of the large shed where it was destroying sawed boards, flooring, piles, joints, window-frames and building paper. To control this disease it was necessary to resaw all the lumber, put in a new concrete floor and thoroughly disinfect the entire establishment. (Weber)

Recent literature:

Humphrey, C. J. The destruction by the fungus"Poria incrassata" of coniferous timber in storage and when used in the construction of buildings. So. Lumb. Jour. 49: 36-37, 49-53. Feb. 1923. 
Decay of lumber and building timbers due to Poria incrassata (B. \& C.) Burt. Mycologia 15: 258 277. Nov. 1923.

The destruction by the fungus "Poria incrassata" of coniferous timber in storage and when used in the construction of buildings. Proc. Amer. Wood. Preser. Assoc. 19: 188-207. 1923.

HOUSE AND FURNITURE

Dry rot caused by Merulius lacrymans Fr.

Connecticut - one report from Wallingford, New Haven County, August. (Graves)

CONIFEROUS SEEDIINGS

Damping-off caused by Rhizoctonia solani Kuhn

Connecticut - isolated patches of seedlings here and there at Cheshire, New Haven County, were killed of white and red pines also white and blue spruce, July 7 . (Clinton)

\section{Recent literature:}

Aullo, M. Resena fitopatologica.forestal. (A survey of forest phytopathology in Spain). Rev. Fitopatologia (Madrid) 1: 9-II. 1923.

Bateman, T., and C. Henningsen. Theory of the mechanism of protection of wood by preservatives. Experiments with hydrocarbons. Proc. Amer. Wood Preservers' Assoc. 19: 136-144. 1923. Boyce, J. S. Decays and discolorations in airplane woods. U. S. Dept. Agr. Bul. 1128: 51. 1923.

Charastelon, R. Sur un procede de conservation des bois. (On process for the preservation of wood). Compt: Rend. Acad. Sci. Paris 176: 1178-1179. 1923.

Cutler, N. L. A contribution to the knowledge of the tree destroying fungi of the Vancouver forestry district. (Abstract) Phitopath. 8: 294. 1923.

Dodge, A. W. Diagnos ing shade tree diseases. Tree Talk. 53: 7-9, 30. 1923.

Doé, Fr. L'öidium et le traitement des forests feuillues du nordest de la France. Rev. Eaux et For. 61: 429-436. Oct. 1923.

Gerry, Eloise. Five molds and their penetration into wood. Jour. Agr. Res. 26: 219-230. 1923.

Haasis, F. W. Root rot as a factor in survival. Amer. Jour. of Forestry 21: 506. 1923.

Hammarlund, Carl. Boletus elegans Schum. und Larix-mykorrhiza. Bot. Not. 4: 305-326. 1923.

Jennings, 0. E. The rulation of smoke, fumes and dust to the vegetation ol the industrial district of Pittsburgh. Trillia. 7: 27-38. Oct. 1923 .

Hansen, T. S., W. H. Kenety, G. H. Wiggin, and E. C. Stakman. A study of the damping-off diseuse of coniferous seedlings. Minnesota Agr. Exp. Sta. Tech. Bul. 15: 35. Apr. 1923.

Harvey, R. B. Cambial temperatures of trees in winter and their relation to sun scald. Ecology 4: 261-265. July 1923.

Humphrey, c. J. Decay of poles and the fungi which cause it. Rept. Special Comm. on Wood Preservation. Amer. Electric Railway Fngincering Assoc. 312: 52-69. mmer. Elec. Railway assoc. New York. 1923. 
PINJ, LONGLAR (Pinus palustris)

*+Leafspot caused by Septoria acicola (Thuern.) Sacc. (Cryptosporium acicolum Thuem.)

Louisiana - Bogalusa, Washington Cuunty, July 27; collected by C. W. Edgerton. "This fungus was first described as Cryptosporium acicjlum Thuem. on leaves of Pinus variabilis collected at Aiken, South Carolina by H. W. Ravenel in 1876. It was identified in 1922 from a specimen from the Florida National Forest (Western Division) on leaves of 3 to 5 year Pinus taeda." (Jenkins)

PINE, ESTERN YELIOW (Pinus ponderosa)

Sweet fern rust caused by Cronartium comptoniae irth.

+ Connecticut - (Clinton). Prior reports: Michigan and New Hampshire.

Gall rust caused by Cronartium cerebrum (Pk.) Hedgo. \& Long

+irisconsin - (Vaughan). Prior report: Penns ylvania.

Rust caused by Cronartium filamentosum (Pk.) Hedga. \& Long.

Washington - Spokane and Stevens Counties. (Heald \& Dana)

Rust caused by Cronartium pyriforme (Pk.) Hedge. \& Long.

Oregon - (Boyce). Prior reports: California, Idaho, *Montana,

Oregon and Washington.

* +Rust caused by Cronartiurn stalactiforme Arth.

Montana - (Weir)

Frost heaving of seedlings

Recent literature:

Honsis, F. Frost heaving of western yellow pine seedlings. Ecology. 4: 378-390. Oct. 1923.

PINE, RPD (Pinus resinosa)

Leafspot caused by Rhizoctonia sp.

+Connecticut - causing considerable loss to one and two-year old

seedlings. (Gravatt). Prior report: Minnesota.

PINE, WHITE (Pinus strobus)

Canker caused by Caliciopsis pinea Pk.

+New York - common about Catskill, Greene County, June 18. (Chupp)

Prior reports: Maine, *Massachusetts and *Pennsylvania.

Learcast caused by IIypoderma strobicola Tub.

+North Carolina - Biltmore, Buncombe County. Prior reports: *Maine, Massichusetts, New Hampshire, Pennsylvania and Rhode Island.

+Wood rot caused by polynorus berkeleyi Fr.

Minnesota - parasitic on roots causing a roddish rot; Itasca County. (Sect. Pl. Path.)

Sun scald of reedles cused by winter injury or drouth.

Nassachusetts - general; rather serious. (Osinun)

STATUS OF WHITE PINE BLISTER RUST CONTROI, IN THE UNTERD STATES IN 1923 (Prepared by J. F. Martin and G. B. Posey, Office of Blister Rust Control)

White pine blister rust (Cronartium ribicolu Fischer) became established in western North America about 1910. The initial source of infection is believed to be a shipment of five-needled pine planting stock from France recoived at Vancouver, British Columbia in 1910. The disease was first discovered near Vancouver in 1921 at which time it was already widely 
spread on both Ribes and pines in western British Columuin nd on Ribes in western Washington. The following map shows the know distribution of blister rust in western North America as of Deombor 31, 1923.

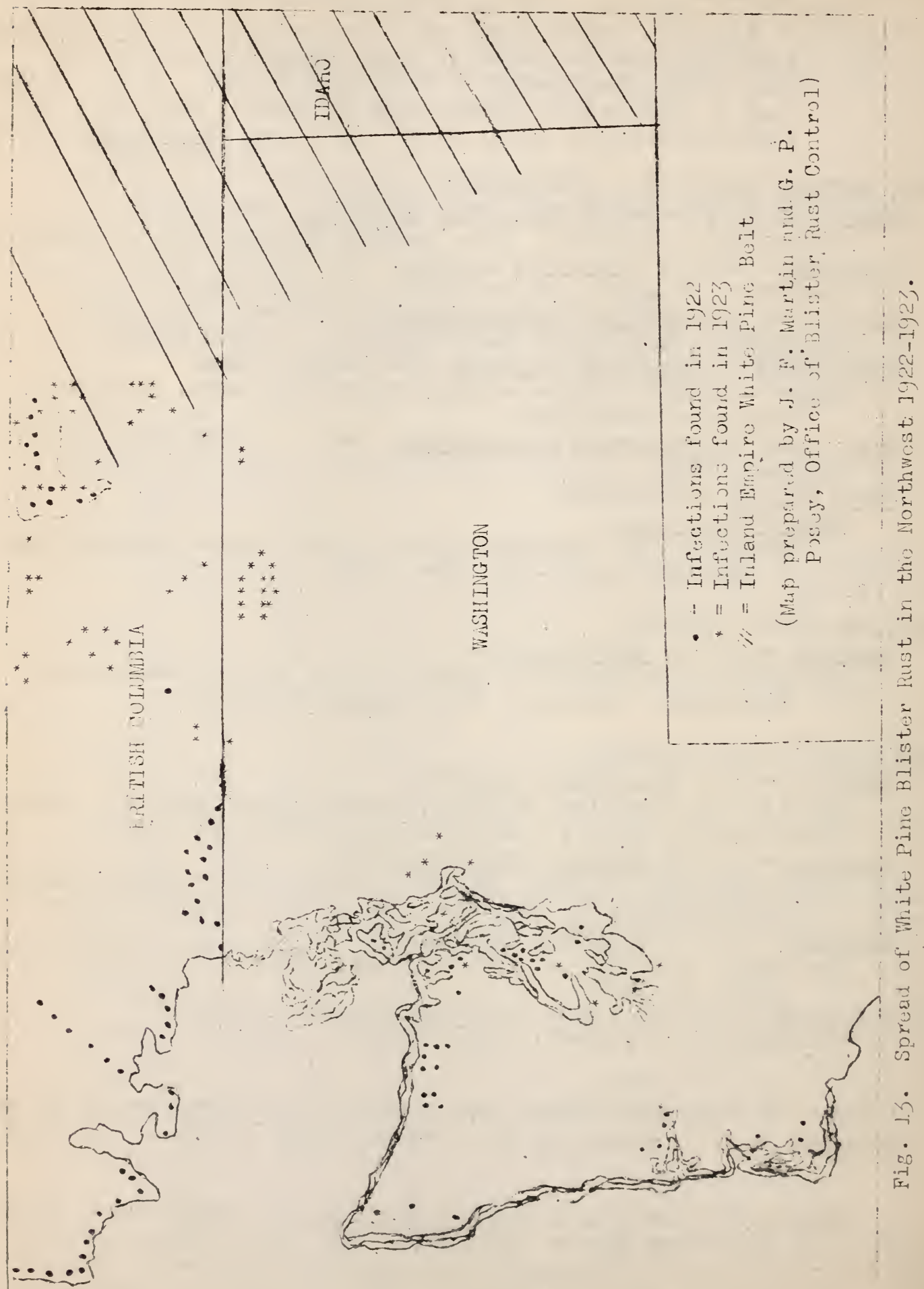


The Eurupean black currant (Ribus nigmun), sometimes called the cultivated black currant, has been chietly ruspunsible for the wide distribution of the blister rust in the Nortivest. Tisis nlant while of nogligible value to horticulture is extremoly susceptible to the blister rust. It becomes heavily diseased at long distarces from an established source of infection and readily establishes new outbreak centers. Because of these facts it is a nuisance in many rogions and the western white pins growing states, including Montana, Iahs, Tashington, Oregon and Culifomin jointly with the U. S. Department $0 \mathrm{i}$ hrioulture are conducting a campaign to eliminate this plant and to discourage its further propagation in order to prevent the rapid extension of blister rust into disease free regions.

During the past two yerirs these primary host plants have been largely climinated in wustorn Montara, northorn Idaho, viestern and northeastern Viashington. The campaign is being vigorously prosecuted in a 11 of these western stitcs including Californis. That the cultivated black currant is an importent fuctur in the initial spread and local ostablishment of the rust is shown by the occurrence of the disese in western Washington. In this reoion, the widespread infection on cultivated black currants resulted from ind borne aeciospores emanting from pine infection centers in British Columbia. The few diseased pines that have been found in western washington ind icate thet the rust first appeared in the state in 1916 or 1977. Five years later (1922) in detormining the distribution of the rust, an inspection of 43,039 European black currants found growing in gardens throughout the 12 infested counties in western Washington, showed that 2.1 percent were diseased. On the other hand, only a trace of the rust was found on the several hundred thousand of other cultivated Ribes examined in connection with this work and even when found diseased, they were always growing next to or among infected cultivated black currants.

In addition to systemutic eradication of Ribes nigrum in these western states, the work consists of control reconnaissance, investigations of the behavior of the rust in the infested region of British Columbia and studies of Ribes conditions in the forested sections of the border states. In cooperation with the U. S. Forest Service, ersication of wild Ribes on netional forests in northern Idaho is being condusted cxporimentally, with a view toward carrying out the ten-year prognim advocated by the Testern Whe Pine Blister Rust Conferenc.

In the Eastern Unitca States there has been practically no change in the linits of the infested regioi. The disesse is present in the lake States, New York, New Eriglund, New Jersey and Pennsylvenia. In general within this $r$ gion, the rust has incroased in volume in unprotected areas with consecucrt incresse in damge to the wite pine orop.

hs the disuse jecumes nure Eentrally established un pine, the per- ntage of Ribes iniucted also incruascs. Some idea jt this increase on cultivated Ribes is ootined fr m data collected in Massachusetts. So far as known, blister rist is buen prosent in that state since abot 1902. Liter it becare stabishod at nany points through the plenting of imported white pines, which med to be more or less inferted with blister rust. In 1917, the insuenition oi 923,000 cultiveted current and gooseberry plants srowing in gardens throughcut the state gave the following results: 
Table 60. Rust infection of cultivated fibes in Nassachusetts, 1917.

\begin{tabular}{|c|c|c|c|c|}
\hline Species & : & $\begin{array}{l}\text { Number of } p \\
\text { inspected }\end{array}$ & : & $\begin{array}{l}\text { Percent } \\
\text { infected }\end{array}$ \\
\hline Black currants (R. nigrum) & : & 47,996 & : & 75 \\
\hline Flowering currants (․ aureum & $:$ & & : & \\
\hline and $\underline{R}$. odoratum & : & 11,999 & : & 38 \\
\hline Red and white currants ( $\mathrm{R}$. & : & & : & \\
\hline vulgare) & : & 754,091 & : & 19 \\
\hline Gooseberries (R. reclinatum) & $:$ & 108,914 & : & 12 \\
\hline Total & : & 923,000 & : & 26 \\
\hline
\end{tabular}

From these results it is seen that infection on cultivated Ribes fifteen years after the first appearance of the rust in the state averaged 26 percent. By species, the percentage of infection varied widely, ranging from 12 percent for gooseberries to 75 persent for black currants, depending upon their relative susceptibility.

In the East, geneml control of the must is actively under way. The intensive service campaik undertaken in 1922 by the Department in cooperation with the infested states has made good progress. About 40 blister rust control agents are ergaged in securing the gineral protection of the white pine crop by furnishing the expert advice, local leadership and supervision needed to promptly obtain the widest possible application of local leadership and supervision needed to promptly obtain the widest possible application of local control measures by pine owners.

During the two years this cooperative control program has been under way, currants and gooseberries have been destroyed on local control areas aggregating $1,377,452$ acres of land in the cooperating states at an average cost of 19 cents per acre. The public is interested in this work and without its excellent cooperation these results could not have been achieved. Some idea of the volume of this cooperation is apparent from the antive participation of 2,139 individuals and 180 towns. These individuals and towns expended $\$ 125,545$ on cooperative control work during the past two years. Also the U. S. Forest Service is cooperating in applying control measures on the White Mountain National Forest. Much of the white pine on this reserve has already been protected from blister rust by the eradication of Ribes.

WHITE PINE BLISTER RUST IN PENNSYLVANIA, 1923

(Proparea by W. A. McCubbin, Department Director, Penisylvania State Department of Agrisulture)

The work of the 1923 season was a continuation of the policy of 1922 , which involved (1) a survy to determino the astual extent of infestation in the state by examinatior or both pines and Ribes, but particularly the latter; (2) a survey of the wild Ribes in the sectiors likely to be soonest affected, to determine the average numbers occurring in four common types of habitat, fencerows, pasture, woodland, ari swamp.

The results were obtained by cooperation of the Bureau with the office of Blister Rust Control of the Federal Bureau of Plant Industry. One man (L. W. Hodgkins) of the Federal Blister Ruct Control staff was detailed to 
scout in the northern cuunties not covered in ly22, his work being directed by this Bureau which also provided nim with a Ford car for transportation. In the period from september 4 to 16 , ho scouted in tles four northern counties, Potter, Tioga, McKean and Lycuming, finding no sign of the disease anywhore on either pines or Ribes.

Table 61. Summary of wild Ribes survey, Pennsylvania, 1923.

TYPE OF COUNTRY*

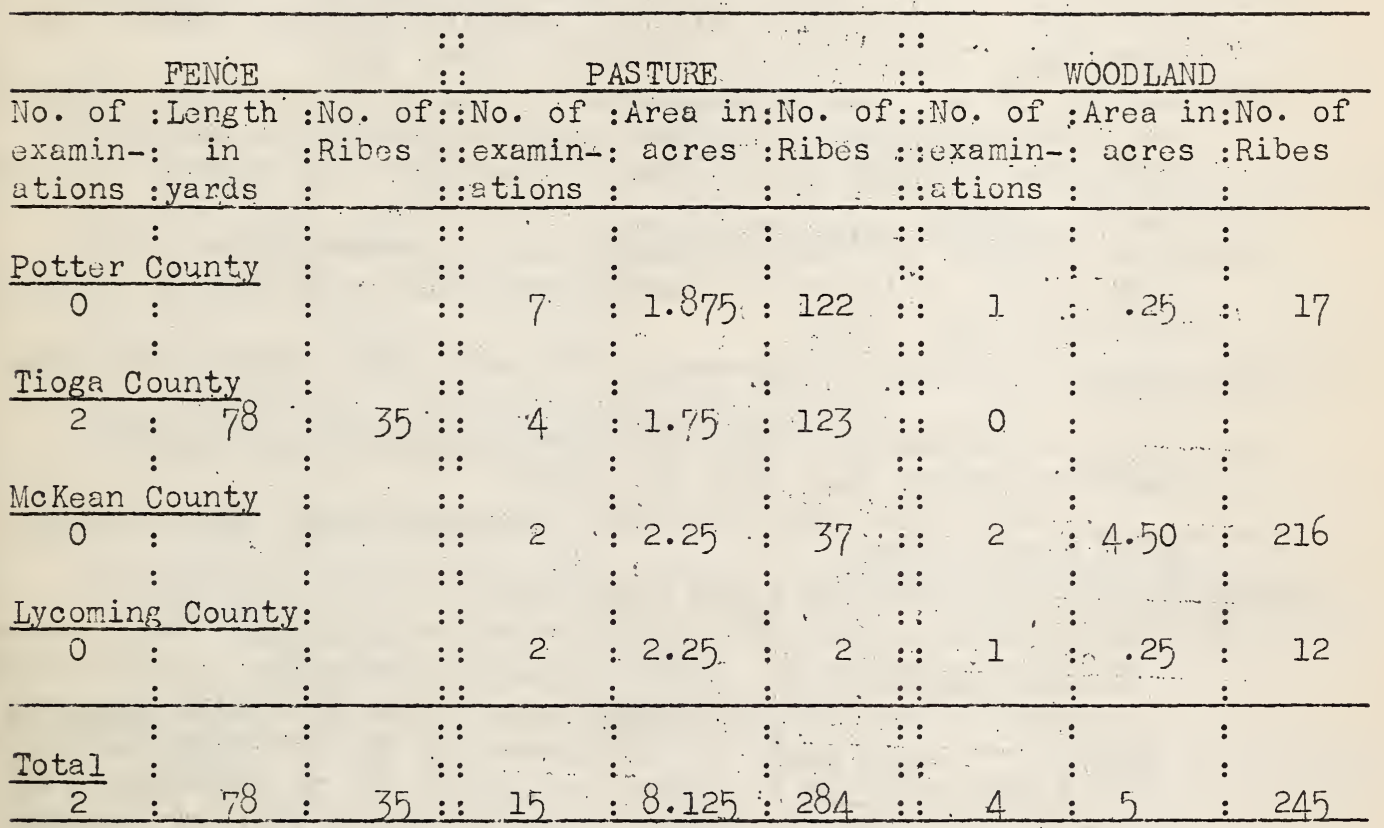

* No examinations made in swamp country.

Recent iiterature

Barss, H. P. and George. A. Root. The monace of the white pine blistor rust. Bienn. Rep. Ed. Hort. Oregon 17: 220-226. 1923.

Baxter, D. T. Wite pine blister rust in Michigan. Phytopath. 13: $285-236: 1933$.

The genus Ribes with reference to the white pine blister rust in the West. Papers Michigan Acad. Sri. 2: 1-2. 1923.

and G. H. Coons. White pine blister rust in Michigan. Quart. Bul. Michigan Agr. Exp. Sta. 5: 193-196. líay 1923.

Cook, Mel. T. Blister must of the white pine. Phytopsth. 13: 283. 1923.

Detwiler, S. B. Spare the currant and spoil the pine. Amer. Forest. $29: 337-340$. 1923

Filler, F. C. Controlling white pine blister rust in the Northeastern States. (Abstract) Phytopath. 14: 53. 1924.

McCallum, A. W. The present status of white pine blister rust in

Canada. (Abstract) Phytopath. 13: 291. 1925. 
Pennington, L. H. Wind dissemination of aeciospores of Cronartium ribicola Fischer. (Abstract) Phytopath. 14: 52-53. 1424.

Posey, G. B. and E. R. Ford. Survey of blister rust infection on pines at Kittery Point, laine, and the effect of Ribes eradication in controlling the disease. (Abstract) Phytopath. 14: 53. 1924 .

Randal1, C.E. Farming the forest for a pine crop. 'Amer. Forest. 29: 195-198, 250. 1923.

Reynola, B. A. Campaign against white pine blister rust may save future California millions. Fruitm. 3: 5, 11-12. Nov. 1923.

Robirson, C. I. Quarantine. conditions in Washington with special reference to white pine blister rust eradication. Month. Bul. Dopt. Agr. California 12: 262-263. June 1923.

Schellenberg, H. C. Die Empfänglichkeit der Ribesarten für den Rost der Woymouthkiafer. (The susceptikility of Ribes species tc White Pino jlister rust) Schweiz: Zeitschr. fur Forstwesen, 74: 25-50. 1923.

Anonyrous. Report of the proceedings and recommendations of the eigth annual blister rust conference held in Boston, Massachusetts, February $\varepsilon-10.1923$.

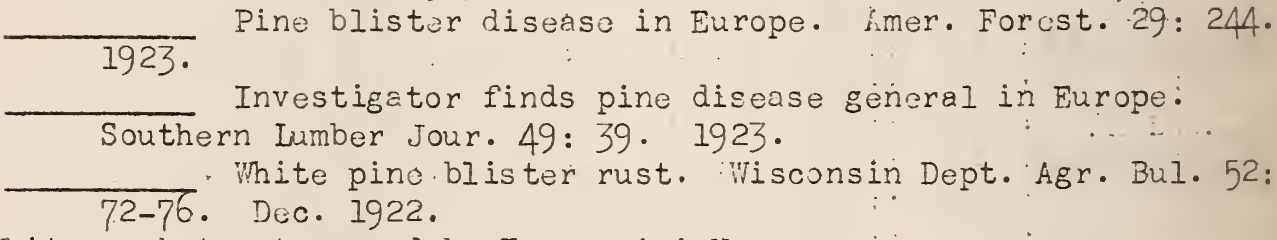
White pocket rot raused by Fomes pini Necs

In Supplement 29 , page $\overline{403}$ a dry rot was reported as being caused by Fomes pinicola Fr.. \& Cke. This was an error as the fungus causing the dry rot was Fomes pini, formerly called Trametes pini Fr. Fomes pini is very common in the White Mountains but Fomes pinicola is ..rather rare, this is an important difference according to Walter H. Snell (Rhode Island) because Fomes pini is the important agent of decay ir white pine while Fomes pinicole is almost negligible. hlso, according to sne 11 the discase is called white pocket rot as dry rot is caused by Merulius lacrymans.

PINE, SCRUB (Pinus virginiana)

Rust caused by Cronartium cerebrum (Pk.) Hedğ. \& Long.

+Dulaware - increusing prevalence found $i$. Sussex and Kent Counties. (Adams). Prior reports: Distriet of Columbia, *Maryland, New Jorsey end Punnsylvania.

\section{- IIVE (Pinus spp.)}

Rust caused by Coleosporium solidaginis (Schw.) Thuen.

+Florida - found very plentiful on young trees ur to eight feet tall; infecting $90 \%$ of the leavos; widespread. (Weber)

Prior reports: Georgia, Mimesota, New iersey and New York. Rust caused by Cronartiuri, nobman ( $3 k$.) Hedge. \& Iong.

* Mississippi - Moy, Attala County. (Neal \& Barker)

Prior reports: Goorgia and Maryland. Leafspot caused by Septoria Ecicola (Thuom.). Sacn.

+Louisiana - is causing troublc in the reforestation projects; of considerable immortance; 100\% injury in one planting. (Edgerton) 
Prior reports: *Missouri and South Carolina. White spot caused by excessive soil temperature

New Hampshire - injury. to secdlings. (A. E. Gravatt)

Damping-off cause uninown

New Hampshire ana Massachusetts. (A. E. Gravatt)

Wisconsin - serious in state conservation' nursery; suiphuric acid control most effective of remedies tried. Pythium sp. may be cause. (Vaughan)

\section{RTIINOSPORA}

+Phomopsis juniperovora Hahn
Pennsylvania - (Hahn)

SPRUCL, BIACK (Picea mariana)

+ Brown heartwood rot caused by Fomes officinclis Fr.

Minnesota - found on a living tree, Itasca county. (Ject. Pl. Path.)

Leaf blister mist caused by Melampsoropsis ledicola (Pk.) Arth.

Minnesota - Carleton County. (Scct. Pl. Path.)

Prior report: *Minnesota.

+Polyporus ciroinnatus Morgan

linnesota - attached to roots, Itasca County. (Sect. Pl. Path.)

+Wood rot caused by Polycorus guttulatus Ph.

Minnesota - Itasca County. (Seot. Pl: Path.)

SPRUCE, SITKA (Picsa sitchensis)

+Red-brown root and butt rot coused by Polyporus schweinitzii Fr.

Oregon - was frequent in an over-mature stand ( 340 to 360 years

old) but in the aggregate the loss was much less than 1\%;

Waldport, Iincoln County, October 9. (Boyce)

+Pecky: wood rot caused by Trametes pini (Brot.) Pr.

Oregon - was occasional in an over-mature stand ( 340 to 360 years

old) the aggregate loss was less than 1\%; Waldport, Lincoln

County, October 9 . (Boyce)

\section{SPRUCE (Picea spp.)}

Stem canker - cause unknown

Connecticut - new to state; forms a resinus canker on branches which finally die; Stanford, Fairfield County, June 26.

(Bartlett \& Cinton)

\section{DISEASES OF HARDWOODS}

ALDER, SPECKLED (AInus incana)

Powdery mildev caused by Erysiphe aggregata (Pk.) Farl.

New York - Tompkins County, July 4. Collected by R. S. Kirby.

(chupp). Prior reports: *Miaine, *New York and *Wisconsin.

Catkin deformetion nused by Eroascus tosquinetii Sacc. (Exoascus amentorum Sade), (Taphrii. amentoruri Sade)

* Minnesota - Itasca County. (Sert. PI. Path.). Prior report: Iaaho. Recent Iiterature:

Klebahn, H. Infektionsversuche mit Taphrina tosquinetii. (Infection experiments with Taphina tosquinetii) - Ber. deutsch. Bot. Geselisch. 41: 10, 1923. 
*+Tuphrina robinsoniana Gies:

New York - Onondega, Oswego and Tompkins Counties, Suptember 8. Collected by F. E. Honey and D. Reddiok. (Chupp)

+ Leafspot caused by Gloossporium sp.

New York - Enfileld Gorge, Tompkins County, July 4. Collected by R. S. Kirby. (Chupp)

ALDER, RTD (Alnus rubra)

Leafspot caused by Cercosporella alni Dearn. \& Barth.

*+Oregon - of negligible importance, Macloay Park, Portland, Multnomah Courty, August 2. (Boyco). Prior report: *Washington.

* +Diaporthe sp.

British Columbia - some dama was being done by the killing of many twigs and branches on trees of all sizes; Qualicum Beaçh, September 5. (Boyce)

Powdery mildow cuused by Microsphaera alni (Wallr.) wint.

*+Oregon - rcire; sriall amount of injury; Waldport, Linsoln County, Octover IC. (Boyce). Prior report: *Washington.

ALDER, HAZEL (A.Inus rugosa)

+ Taphrina robins oniana Gies.

* Maryland - vicinity of Cabin John, Montgumery County, autumn; collected by E. K. Cash and A. E. Jonkins. (Jenkins)

*Virginia - vicinity of Black Pond, Fairfax County; collected by A. E. Jenkins, July 12, 1922. (Jenkins)

ALNUS, MOUNTAIiv (hinus tenuifolia)

*+Exoascus spp.

Oregon - Oregon Caves, August 26; collector R. Kent Beattie; apparently. two different species present, one on leaves and the other on fertile catkins. (Jonkins)

ASH, WHITE (Fraxinus americana)

Anthracnose caused by Gloesporium aridum Ell. \& Holw.

Connecticut - only complaint of injury to shade trees for several years; Portland, Midadesex County, June 20. (Clinton)

Prior reports: Connectinut, District of Columbia, Massachusetts, and *Wisconsin.

Luafspot caused by Glocosporium sp.

+ Jew York - common in Cascaúilla, Goore and Ionpkins Counties, October 10. Collected by E. F. Guba. (Chupp)

Prior reports: Delaware and Massachusetts.

Leafspot caused by Phyllostiota sp.

New York - common; Tompkins County, Septeriber 10. (Chupp)

Rust causcd by Puccinia peridermiospor: (E11. \& Tr.) Arth., ( nata (Ik.) hirth.), (Acoidikn fraxini Sohw.)

Connocticut - of average import noc; Fairfield, Now Hâven, New London and Middlesex Counties.

+New York - in one case nokrly alj. the leaves of a very large treo wore suveroly affected causing dying of trees: Nasscu and Suffolk Counties; also reported as "all over a number of five-year old trees." (Chupp)

Prior reports: *Colorado, Comnecticut, Dolaware, *District of Columbia, *Illinois, Iowa, *Mussachusetts, Minnesota, *Missouri, *INebraska, *Pennsy Ivanir and *ïisconsin. 
*+Canker caused by Sphaerographium fraxini (Pk.) Sacc.

New York - sorere on one tree cavsing killing of brunohes; Wyoning Cuunty, iugust 24. Collected by E. F. Guba. (Chupp)

ASH (Fraxinus spp.)

White heartwod rot caused by Fumes fraxinopilius Pk.

Missouri - caising a heart rot of living trees, Taney and Texas

Cunties. (Rhoads)

aSi, MOUNTAIN (Sorbus americana)

Rust caused by Gymnosporangium globosum Farl.

* New York - Water Mill, Suffolk County, June 25. Collected by

S. W. Squires. (Chupp)

Prior reports: Muire, *Massachusetts and Vermont. Winter in iury

Mashington - Okanogan County. (Heala \& Dans)

ÁSPEN - Seo Populus tremulaides

BASSIOOD - See Linden

BIRCH, FUROPFAIN MITE (Betula alba)

Cunkor caused by Melenconium bicolor Nees.

Tiew York - killing top of tree; a veak p r rite; Genosee County, hugust.2. Colleoted by F. F. Guba. (Chupp)

Prior reports: *Indiana and New York.

BUTMRNU (éuglans, cinerea)

Arthracnose caused by Gnomonia leptostyla (Fr.) Ces. \& Deliot. (MarsSunia juglandis (Iib.) Saco.)

New York - defoliates most of the trees in the state; found wherever buttersuts are grown; Wayne County, hugust 10. (Chupp)

Prior reports: *IIInois, Indiaria, *Iowa, *Messachusetts, Michigan, *Mississippi, New York, *Ohio, *Pennsylvanië, *Washington, West Virginia and * Jisconsin.

ChIPHOR (Cinnamomum cemphora)

+Colletotrichum sp., +Gloesporium sp., Pestalozzia sp., +Phoma sp., and +Ieptothyrium pomi (Mont. \& Fr.) Sacc. Thuse organisms have Deon collected in Plorida as parasitio upon tho host plant and doing considerable damage; names in ordur of importance; the anthracnose diseases were by far the most important; a severe utbreak wis reported from Perry in which a considerable number of treos were lilled, it was found that the severity of the disuase was probably due to associntion with thrip injury. (Wever)

CATALPA (Catalpa sp.)

Puwdery mildew caused by Wicrosphaera alni ver vaccinii (Schw.) Salm. *+New York - Wayne County, JuIy 10. Collected Oy R. S. Kirby. (Chupp)

+Delèware - appeared very preválent following htavy rains in Suptember, New Castle County, September 29. (hadums).

Frior reports: Connecticut, *District of columbia, *Illinois, *Indiana, Massachusetts, *Nebraska, *O io, *Pennsylvania and West Virginia. 
Leafspot caused by Phyllosticta catslpae EII. \& Mart.

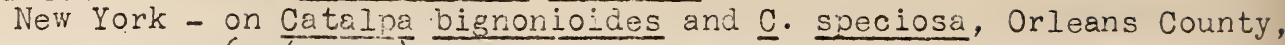
June 26. (Chupp)

Ohio - causes malformation and defoliation of leaves; of rather general range in state; associated with catalpa midge spot; Wayne County, July. (Detmers)

Prior reports: Delaware, *District of Columbia, *Indiana, *Kentucky, Louisiana, *Maryland, *Massachusetts, Michigan, *Mississippi, Missouri, New Hampshire, New Jersey, New Mexico, *Ohio, Pennsylvania, *South Carolina and West Virginia

Leafscorch caused by high temperatures.

Kansas - Douglas County. (ithite)

CERCIS SP. - See Redbud

CHERRY, MESTERN CHOKS (Prunus demissa)

+ Leafspot caused by Septogloeum nuttallii Hark.

Oregon - rare; Macleay Park, Portlend, Multnomah County, hugust 2. (Boyce)

CHERRY, PII (Prunus pennsylvanica)

+ Ieafspot caused by Coccomyces sp.

Now York - Cattaraugus County, June 25. Collected by Kirby and Honey. (Chupp)

CHERRY, BLUCK (Prunus serotina)

Shot hole caused by Coccomyces lutescens Hig.

+New York - general; Nassau County, June 9. Collected by Kirby and Honey. (Chupp). Prior reports: Georgia and Illinois.

Blark knot caused by Plowrightia morbosa (Schw.) Sácc.

* +New York - Nassau County, June 9. Collected by W. D. Mills. (Chupp)

Prior reports: *Alabama, Connecticut, *Maine, *Maryland, Massachusetts, Minnesota, Pennsylvenia and *west Virginia.

Brown rot causea by Sclerotinia seaveri Reade

New York - new for state; Dutchess County. (Guba); Tompkins County, June 11. (Chupp)

Prior reports: *Iowa, *Virginia and *Wisconsin.

CHERRY, COMON CHOKE (Prunus virginiana)

+ Shot hole caused by Coccomyces lutescens Hig.

New York - very common everywhere, Tompkins County, May 16. (Chupp)

Black knot caused by Plowrightia morbosa (Schw.) Sacc. (Dibotryon morbosum The issen \& Sydow)

Minnesote - found chiefly on Prunis virginiane throughout stete, Remscy County, May Źc. (Suct. Pl. Path.)

Prior reports: Connecticut, Iowa, *Missachusetts, Minnesota and Montana.

Powdery mildew caused by Podosphaera oxyacanthae (DC.) Deby.

New York - Tompkins County, Jine 11. (Chupp)

Prior reports: *Colorado, Connecticut, *Massachusetts, Minnesota, *l: ontana, *South Carolina, New York and *North Drkota.

Brown rot caused by Sclorotinia angustior Resde

* +1 We' York - common and statewide; Tomplins County, May 13. (Chupp \&

Guba). Prior report: *Iorth Dakota. 
+Brown rot caused by Sclerotinia demissa Dana

Minnesota - unimportant but interesting; more prevalent than in 1922; causes a twig blight; runges over suathern half of stạte; puriod of Greatest injury May 18 to July l; heavy infections fter each rain; Prunus virginiana very susceptiblo, Rumsey County. (Sect. Fl. Path.)

CHESTNUT (Castanea dentata)

Canker caused by Endothia parasitica (Murr.) Anderson

"This discase continued its rapid spread during

1923. h large spot infection was found covering parts

of Greenville County, South Carolina, and Henderson

and Polk Counties in North Carolina as noted in a

previous bulletin. Later inspections have shown

that the disease was present in 19.23 on a large area in

Union, Fannin and Gilmer. Counties, +Georgia, and in Polk

County, +Tonnessee.

"is number of chestnuts, mostly of Asiatic origin,

have survived the attacks of the blight. These trees are recorded when reported by verious parties and a number of them have already been inspected. It is hoped in this way and by systematio field inspection, to lonate the strains of chestnut whioh will be sufficiently resistant to the blight that the chestnut will continue to be one of our viluable nut and ornamental trees.

"The map (Fig. 14) showing the present distribution of the disease is based upon vory limited field inspection, as funds available for chestnut blight work are small. A number of countios have beer included with in the infected zone, although it is not known that actual infection ucours within tiem. They are plac ad there on account of their nearness to large infections and the certainty that infections would be found in them on inspection."

Prior reports: hlabama, *Connecticut, Delaware, Indiana, Iowa, Kansas, * Kaine, *Maryland, *Massachusetts, Michigan, Missouri, *Nebraska, New Hampshire, New Jersey, *New York, *North Cerolina, Ohio, *Pennsylvania, *Rhode Island, South Carolina, Vermont, *Virginia and *West Virginia. (G. F. Gravatt)

+Powdery mildew caused by Microsphaero alni (Wallr.) Wint.

Connecticut - Kent, Litchfield County, October 11 . (Clinton)

New York - Brome, Cort Ind, Onondaga and Tompkins County, July 4. Collected by R. S. Kirby. (Chupp)

Powdery mildew caused by Phyllactinia corylea (Pers.) Karst.

+New York - Schuyler County, August 2. Collected by R. S. Kirby.

(Chupp). Prior report: *Indiana.

+Brown checked woodrot caused by Polyporus sulphureus (Bull.) Fr.

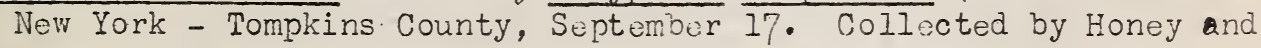
Guba.

Bacterial leafspot - cause unknown

Kansas - one tree out of thirty-one infected; severe infection

caused leaf drop, July 10. (White) 


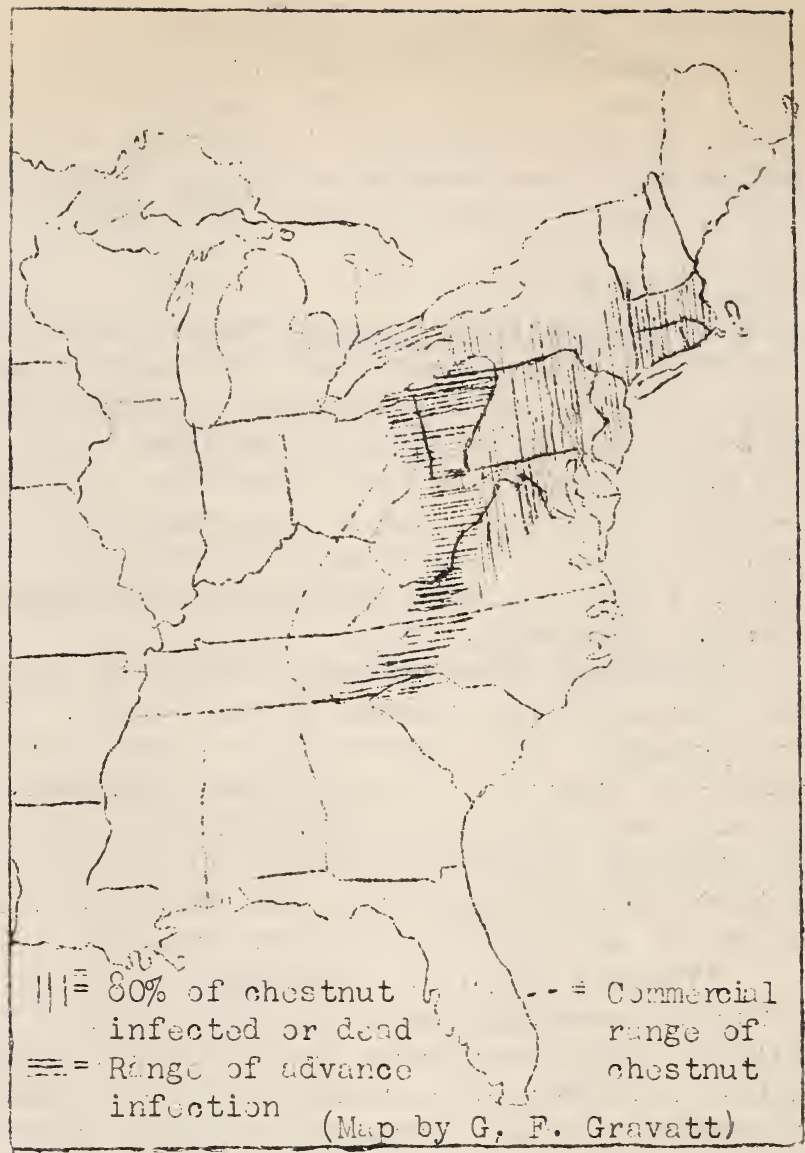

Fig. 14. Known distribution of rihestnut blight, 1923 .

Recont literatur:

Belsani, F. Il mie dell'inchiostro nei castagneti. Il coltiv. 69: 278-281. Mir. 1)23.

Biors, P. L Schizophyllum cummune Fries sur Chätaignes du Japon. (Schizophyllum commune Fries on Jupanese Chestnuts.) Rev. Path. Veg. et Fnt. Ar. 101: 151-153. 1923.

Dufrénoy, J. Lus malidies dra shataigniur. (Thu discasos of the chestnut.) Cumpte Rendu du Congres Regional a Brive. 45-63. 19z2.

LoPriore, Giuscppo. The "ink disease" of the chestnut. Int. Rev. Soi. \& Pract. Agr. 1: 600-607. July - Sept. 1923.

Mangin, L. «. The restoration of chestrut wosds. Intern. Rev. Sci. \& Pract. Agr.'n. s. 1: 37-42. Jan. - Mar. 1923.

Marchal, Puli. Recherchos sur les milaảies dos chataigniers. Ann. Epiph. 9: 134-135. 1923.

Petri, Ji: Sul modo di diffondersi del mal doll'inchiostro del Castüno $\epsilon$ sui muzi piu efficaci per combattorlo. (On the mode of spreud of the ink disease of the chestnut and on the most efficasious means of control.) Nuovi Ann, Min. igr. 3: 3-19. 1923.

Picciuli, L. Nonografia del Castrgn, (Morogriph on the chestnut). 3: 3)\%. 1922.

Soholl, T. Diswases of the French Chestnut, troe -- particularly tho ink mialady. Jour. Amer. Leather Chem. issoc. 17: 353-359. 1922. 
CHINABERRY (Melia azedarach)

Canker oaused by Nectriu sp.

+Mississippi - a rather serious blighting of the limbs was caused

by this disease, appeared to be widespread throughout the

state. (Barkor \& Neal)

+Root rot caused by Oz nnium omniv orum Shear

Arizona - Pima and Yuma Counties. (Brown)

CHINQIAPIN, GIKNT (Castanopsis chrysophylia)

+ Leafspot caused by Dothidella castanopsidis Dearn.

Oregon - common but caused little injury; Hood River and Lane Counties. (Bopgee)

COFFFR TREE, KEITUCKY (Gymnoledus dioica)

Leafspot caused by Cercuspora gymnoladi Elll. \& Kell.

Miss uri - Columbia, Boone County, September 28. (Maneval)

Prior reports: *Illinjis, *Kansas, *Miss juri and *Nebraska.

DOGWOOD, PAGODA (Cornus alternifolia)

Powdery mildew cạu sed by Micrusphaera alni (Nallr.) Wint.

New York - mompkins CJunty, August 18. Collected by E. E. Honey. (Chupp)

Prior reports: *Connecticut, Iowa, *Massachusetts, *New York and *Penns ylvania.

DOGWOOD, PACIFIC (Cornus nuttalli)

Powdery.mildew caused by Phyllactinia coryled (Pers.) Karst.

Oregon - was more or less common but caused little injury; Portland, Multnomah County, October 22. (Boyce)

Prior reports: *Oreg on and *Washington.

DOGWOOD, RED (Cornus occidentalis)

Powdery mildew, caused. by Phyliactinia curylea (Pers.) Karst.

+Oregon - rare; Portland, Multnomah County, Ontober 22. (Buyce)

Prior report: *Washington.

DOG:HOOD, ROUNDDLFAF (C Jrnus rugosa)

+ Flyspeck cause undetermined

New York - Tompkins Cjunty, kugust 4. (Chupp)

DOGWOOD, RED OSIER (Cornus stolunifera)

Powdery mildew caused by Microsphacra alni (Wallr.) Wint. +Wow York - Tompkins C Junty, August 18. Collected by E. E. Honey.

(Chupp). Prior report: Hiso onsin.

DOGHOOD (Cornus: sp.)

Leafspot caused. by Cercospora cornic Ja Tr. \& Earle

+Flurida - was a vory conspicusus aisease; in every case severe, often causing complete defoliation in early summer; common on native and cultivated plants and widespread. (Teber)

Prior reports: *Mississippi and *Texas.

Sarcinclla heterospora Sācc.

*+Missouri-Columbia, Boone Counties. (Maneval)

Prior report: *West Virginia. 
Leafscurch caused by weather

New York - in park at Rochester, Monr e County, September 21; collected by Honey and Kirby; observed on the following Cornus species: alba, koenigii, koreana, kousa and mas. (Chupp)

EIDER, AMERICAN (Sambucus canadensis)

Powdery mildew caused by Microsphaera sp.

+New York - conidial stage; Cayuga (September 15); Monroe and On undago Counties. (Chupp)

Leafspot caused by Phyllosticta sp.

*+New York - Queens Cunty, Septenber 3. Collected by W. D. Mills. (Chupp)

Rust caused by puccinia sambuci (Schw.) Arth. (Puccinia bolleyana Sacc.) (Dicae Jma sambuci (Schw.) hrth.)

*+New York - Cayuga, Tompkins and Wayne (July 10) Counties. Collected by R. S. Kirby. (Chupp)

Prior reports: *Georgia, *Indiana, *Iowa, *Maryland, *Massachusetts, *Mişsissippi, *Nebraska, *Ohio, *Pennsylvania and *Virginia.

EIM, AMERICAN (UImus americana)

+Heart rot caused by Collyjia velutipes Fr.

Minnosota - Itasca County. (Sect. PI. Path.)

Blsck spot caused by Gnomonia u.Imea (Sacc.) Thuem. (Duthidella ulmi (Dur.) Wint.) (Gloeosporium ulmeum Miller) (Phyllachora ulmi Fckl.)

New York - statewide; very severe on individual trees; other intermingling trees may not be affected; T mpkins County, July. (Chupp)

+Minnesota - Fillmore Cunty. (Sect. Pl. Path.)

Prior reports: Connecticut, Illinois, Indiana, *Iowa, *Maine,

*Mississippi, *Nebraska, *New Yjọrk, *North Dakota, *Texas, and *West Virginia.

Heart rot caused by Polyporus squamosus (Huds.) Fr.

+New York - Putnam Cunty, June 17. Collected by Kirby and H oney. (Chupp). Prior report: Minnesotá.

+Canker caused by Sphaeropsis uImicola Ell. \& Ev.

Pennsy lvania and Maryland. (Hahn)

EIM, ENGLISH (Ulmus campestris)

+Canker caused by Sphaer sps is uImicola Ell. \& Ev.

Pennsylvanis - (Hahn)

ELM, CORK BARK (Ulmus foliacea suberosa)

+Canker caused by Sphacr ppsis ulmicjla Ell. \& Ev.

Pennsy lvania. - (Hahn).

EIM, SLIPPERY (Ulmus fulve)

Blackspot caused by Gnomonia ulmae (Sacc.) Thuem.

+New York - statewide.in distribution. (Chupp)

Prior reports: Illinuis and *Indiana.

EIM, CHINASE (Ulmus parvifolia)

+Root rot caused by Ozonium omnivorum Shear

hrizona - Greenlee and Pima ( 5 trees killed in Tucson) Counties; this host has been $r$ eported as being resistant tu this organism. (Br วwn) 
EIri (Ulmus spp.)

Blacksnot caused by Gnomanis ulmae (Succ.) Thuem.

Connecticut - an average amount; Hortford, New Haven, Middlesex and Now Iund on (Hodlyme July 5 ) C suntins. (Clinten \& Stoddard)

thlabama - important locally, caused early dufoliution; Elmer County. (Miles)

Oklahoma - very prevalent; Payne County, October 15. (Stratton)

+Missouri - very common every year. (Maneval)

+Kansus - somewhat generel. (Witet.

Canker caused by Sphioropsis ulmicila Bil. \& Ev .

+Ohio - (A. F. Grevatt)..

Wiscunsin - of major importance; more prevalent than average year;

found mostly in the eastern and southern sections of the

stute; was. the cause of affected trees in 26 . nurseries to be con-

derned and destroped; not found in the woods. (Vaughan)

Prior report: Visconsin.

Powdery mildew ciused by Uncinula macrospora Pk.

+Oklahoma - not prevalut, Payne County, November 4. (Stratton)

Prior reports: : *Illinois.,...Iowa, *Kansęs, *Messachusetts, Nebraska,

*New York, *iNorth Carolina, Ohio and South Car olina.

Spray injury caused by arsenate of lead and unknown factors

Connecticut - three complaints; F irfield (Norwalk, June 24) and

New London Counties. (Clinton).

Canker cause unknown

Connecticut - new, to state; a Nectria-like caniser in bark, often very large; sam similar cankers at Amherst, Massachusetts, where the trouble has been knom some time; Now Haven and Stamiora Post Road, June $26 . \quad$ (Clinton)

Recent literature:

Malaquin, A. Ia maladie des Ormes. (The disease of the elms). Renaiss. Agr. 4: 91-94." 1923.

Schwarz, M. B. Das zwergsterben der ulmen, trauerweiden und pfirsichbäume Meded. Phytopsth. Labor Willie Comm. Scholt. Amst. 5: 73. Dec. 1922. Graphium ulmi n. sp., Phoma intricans n. sp., Litteraturverzeichnis.

Spierenburg, Dina. A new elm tree disease. Rep.t. Internat. Conf. Phytopath. \& Econ. Entomol. Holland: 123-124. H. Veenman \& Sons, Wageringen, $192 \%$.

Suringar, J. V. Dine Ulmenkrankheit in Hollend. Mitt. Dent. Dèndrol. Gos. 32: 145-147. 1922.

EUCALYPTUS (Fucrlyptus sp.)

Recent liter ture:

Moore, Don R. Suscoptibility of ucalyptus to dr ught. hustralian Forest. jour. 6: 171-172. 1923.

Murrill, w. A. Porie cocos (Schv.) F. h. Wolf. Mycologia 15: 105-106. 1923.

GUM, SWEET (Liquidamoar styraciflua)

+Loafspot caused by Soptoria sp.

Florida - caused a complete defoliation of the gum trees situated on the campus of the University of Florida in the middle of the season; it was not reportec elsewhere. (Tober.) 
HímTHORN, BL4CK (Crataegus d Juglasii)

Incense cedar rust caused by Gymnosporangium blasdaleanum (Diet. \& Holw.) Koarn.

Oregon - hypertrophied leaves and young shoots, but tutal damage was slight, Lane County. (Boycé)

Prior reports: *Oreg on and *California.

HAITHORN, SMALL FRUITED (Crataegus spathulata)

Rust caused by Gymnosporangium floriforme Thax.

+Mississippi - a heavy infection in Oktibbeha Cunty, September 15 . (Neal \& Barker). Prior reports: *Alnbama and *Arkansas.

HAWTIORN (Crataegus thayer)

+Scib caused by Venturia inaequalis (Cke.) Aderh.

New York - Rochester Park, Rochester, Monr je County, September 22. (Chupp)

HAiNHORN (Crataegus spp.)

Fire blight caused by Bucillus amylovorus (Burr.) Trev.

New York - generel throughout the western half of state, Tompkins County, iugust I; found by Kirby and Honey at Rochester Park, Rochester, Monroe County, on the following Crataegus species: +illinjierisis, oxyacantha, tomentosa, a trace was found in each instance. (Chupp)

Leafspot caused by Fabraea naculata (Lóv.) Atk. (Ent omosporium macuIaturn Lév. I

+New York - caused defoliation; Rhinebeck, Dutchess County, September I. Cullectad by $\mathrm{E}$. F. Guba. (Chupp)

Rust caused by Gymnosporangium betheli Kern

* +North Dakota - of general range; unimportant.except in few cases;

Fargo, Cass County, June 26. (Weniger)

Prior reports: *Colorado, *Montana and *Utah.

Rust caused by Gymnosporangium germinale (Schw.) Kern (Roestelia aurantiaca $\mathrm{Pk}$.

*+Connecticut - Kent, Litchfield County, October 1l. (Clinton)

New York - Orleans (August 10) and Tompkins. (Kent, October II)

Counties. Colleoted by Fernow.

Prior reports: arkansas, Delaware, *District of Columbia, *Georgia,

*IJuis íina, *Maryland, *Massachusetts, *Mississippi, *New

Jersey, *New York, *Ohio, *Pennsylvania, *Suuth Carolina,

*Texas and *Virginia.

Rust caused by Gymnosporangium juniperi-virginianae Schw. (Roestelia penicillata Farl.)

+ Connecticut - Litchfield Cunty. (clinton)

* +New York - Westbury, Nassau County, iugust 10. Collected by W. D. Mills. (Chupp)

Ohio - Wayro County, August. (Detmers)

Prior reports: *Kansas, *IJebraska und *Vermont.

HAZLENUT (Corylus californica)

Lufspot caused by Septoria corylina Pk.

*+Cregon - (Boyce). Prior report: *California. 
Connecticut - North Stonington, New Lond on County, September 18. (Clinton)

Prior reports: *Alabama, *Georgia, Massachusetts, *New York, Ohio and South Carolina.

HORSECHESTNUT (Aesculus hippocastanum)

Leaf blotch caused by Guignardia aesculi (Pk.) S.tew.

Has been found in Alabama, Connecticut, *Delaware, *District of

Columbia, IIIinois, Indiana, Iowa, *Ma ine, *Mary land, *Massa-

chusetts, Michigan, Minnesota, New Hampshire, *New Jersey,

*New York, Ohio, Pennnsylvania, Rhode Island, Utah, *Virginia,

*West Virginia and *Wisconsin.

Coral spot caused by Nectria cinnabarina Fr.

New York - in many cases infected trees were weakened by Guignardia aesculi (Pk:) Stew and the coral spot completes the killing of the branches; Tompkins County. (Chupp)

Prior reports: Connecticut, *Maine, Massachusetts, New Hampshire, New York and Rhode Is land.

IVY, POISON (See Sumach, Poison)

IINDEN, AMERICAN ( Tilia americana)

+ Leaf'spot caused by Cercospora tiliae Pk.

New York - Tompkins County, July 4. Collected by R. S. Kirby.

(Cr $\lambda$ po)

Powdery mildew caus by Uncinula clintonii Pk.

*+New York - Enfield George, Tompkins County, July 4. (Chupp)

Prior reports: *Connectiaut, *Florida, *Illinois, *Indiana, Iowa, Massachusetts, *Michigan, *Minnesota, *New Hampshire, *New

York, *North Dakota, Ohio and *Visconsin.

+Flyspeck - cause undetermined

New York - on stems; Tompkins County, August 4. (Chupp)

MAGNOLIA (Magnolia spp:)

Anthracnose caused by Colletotrichum sp.

+Floride - well distributed but caused little damage to foliage or

twigs. (Weber). Prior report: South Carolina.

Leafspot caused by Phyllosticta cookei Sacc. (Phyllosticta magnoliae Cke.)

Mississippi - very prevalent in many of the coast counties; in some

cases it was so severe that shade trees became unsightly;

Harrison Cuunty, April 10. (Neal \& Barker).

Prior reports: *California, *Mississippi, New York, and South Carolina.

MANZANITA (Arctostaphylos manzanita)

Witches broom caused by 'Exobasidium vaccinii (Fokl.) Wor.

Oregon - not common; little injury resulted; Homestead Inn, Hood River County, July 25. (Boyce)

Rust caused by pucciniastrum sparsum (Wint.) Ed. Fisch.

Oregon - was unimportant; Homestead Inn, Hood River County, July 25. (Boyce)

MAPLE, VINE (icer circinatum)

Leafspot caused by Septoria circinata Ell. \& Ev.

+oregon - abundant but causing little damage to the host; Rujada, Lane County, June 17. (Boyce). Prior report: *Washington. 
MAPLE, SILVER (Acer dasycarpum)

Blight caused by Taphrina $\mathrm{sp}$. see Acer spp.

MAPLE, OREGON (i.cer macrophyllum)

Leafspot caused by Cercosporella aceris Dearn \& Barth.

*+Oregon - killed some leaves but did little injury to host, Macleay

Park, Portland, Multnomah County, sugust 2. (Boyce).

Prior report: *Washington.

Black speckled leafspot caused by Rhytisma punctatum Fr.

*+Oregon - was of negligible importance; Macleay Park, Portland,

Multnomah County, October 28. (Boyce)

Prior reports: *California and * Vashington.

Leafspot caused by Septoria circinata Ell. \& Ev.

+Oregon - was of negligible importance; Macleciy Park, Portland,

Multnomah C sunty, July 29. (Boyce). Prior report: Washington.

MiPLE, BOX ELDER (iicer negundo)

Red stain caused by Fusarium negundi Sherbakoff

Recent literature:

Hubert, E. E. The red stain in the wod of box elder. Jour. Agr. Res. 26: 447-458. 1923.

Fusarium Sacc. (flabama and *North Dakuta) and Fusarium

pyrochroum (Desm.) Sacc., (*District of Columbia).

Leafspot caused by Phyllosticta minima (Berk. \& Curt.) Ell. \& Ev.

Connecticut - Wapping, Hartford County, July 20. (Clinton)

Black speckled leafspot caused by Rhytisma zunctatum Fr.

*+New York - (Dept. PI. Path.)

MAPLF, BIfCK (HCer nigrum)

Blight caused by Taphrina sp. see Acer spp.

MiPIF, NORifiY (Acer platanoides)

Leafspot caused by Gloeosporium sp.

*INew York - Bergen, Genesee County, July 16. (Dept. Pl. Path.)

Prior reports: Connecticut, New York and Virginia.

Leaf fall ceused by drought

Connecticut - under severe drought conditions laaves seem to drop off while still green; Whitneyville, New Heven County, June. (clinton \& Stoddard)

MiPLE, RED (Acer rubrum)

+Dodder, Cuscuta gronovii Willd.

New York - Onondaga County, September 15. Collocted by E. E. Honey. (Chupp)

Blight caused by Tunhrina sp. see icer spp.

MAPLT, SUGAR (

* +ilternnria sp.

Iowa - Grinnell, Poweshick County, Octobor. (Conard)

+Leaf blight caused by Gloeosnorium sp.

New York - occasional tree severely injurod; Erie County, June 25.

(Chupp)

Powdery mildew caused by Uncinula circinuta Cke. \& Pk.

+iNew York - Ithana, Tompkins Cunty, Ontuber 1. Collected by E. E.

Honey. (Chupp). Prior reports: *Indione and Iowa. 
Frost injury - physiological

Ohio - widespread damage was cone to sugar maplos in particular and other hardwood trees by the snow storm and severe frost of viay loth throughout central, northerr and eastern Chio. Though a large number of varieties of shade trees were damaged, the sugar maple suffered the greatest injury. The young leaves in the tops of the trees had just developed and were kilied by the frost. Buds in the other parts of the trees were swelling, so that the frost injured the leaves within. (Detmers).

WhPLE, MOUNTAIN (hoer spicatum)

Leafspot caused by Phyllosticta minima (Berk. \& Curt.) Tll. \& Ev. +New York - Tompkirs County, July 4. Collected by R. S. Kirby.

(Chupp). 'Prior report: Wisc unsin.

* +Blight causeá by Taphrina lethifer (Pk.) Sacc.

New York - Elizäbethtown, Essex County; collecter by C. H. Peck, cune 1886; apparently the only collection of this species; specimen received from Dr. House. (Jenkins)

MAPIE (Acer spp.)

+Twig canker caused by Macrophoma sp. New York - Big Indian Slide Mountain, Ulster County, June 6. Collected by E. F. Gubą. (Chupp)

Canker caused by Nectria cinnabarina Fr.

+Karsas - kili ing tops of maples; Pittsburg, Crawford County.

(White). Prior reports: New York, *Ohio, Pennsylvania, Mássachusetts and Washington.

Sap rot caused by 'Pholiota adiposa Fr.

+Delaware - observed locally as a wound parasite. (Adams)

Prior reports: Massachusetts and New'Hampshire.

Leafspot caused by Phyllosticta sp.

${ }^{*+G e o r g}$ ia - common on sapling maples in wods on hgricultural

grounds; Athens, Clark County, June: 21. Collected by R. J.

Haskell. Prior reports: Conrecticut.

Heart rot caused by Polyporus gilvus Schw.

+New York - found on a shade tree; Kingston, Ulster County,

September 23. Collected by E. F. Guba. (Chupp)

Tar leafspot caused by Rhytisma acerinum Fr.

Connecticut (Clinton), New York (Chupp), +Florida (Weber).

Recent liter ture:

Jores, S. G. Life history of Rhytisma acerinum (Preliminary Acc ount). Arn. of Botany, 37: 731-732. 1923.

Felty fungus caused by Septobasidium pedicillatum (Schw.). Pat.

+Florida - the fungus was smothering growing tops of young twigs;

Gainesville, Alachua Courty. (Weber)

Leafspot and blight caused by Taphrins spp.

Report prepared by Anna E. Jenkins, Office of Plant Disease Survey

and Pathological Collections.

Maple, sugar (Acer saccharum)

hpparently epiphytotic in certain localities in a number of states in 1922; identified from specirens sent to the Department in June 1922 from the following states: 
Maine, Rockport - specimens gubmitted by W. J. Morse, Orono, Maine.

New Hampshire, Center Conway - from Charles Bairt who describes the symptoms as follows: "The leaves of our fine trees show dark spots on them, then shrivel up, turn black and die, loaving, the limbs entirely bare."

New York, Andover - from Berrice Nye who states: "We have one tree which is dying from some disease. Last year ore tree died in the same manner. The tree loaves out cnd lojks perfectly healthy, then after the leaves are partly grown they turn black and fall off. Two trees near this one are partly affected."

Pennsylvania - specimen submitted by I. O. Overholts. Ohio, Antioch, Antioch College - from O. L. Inman who mentions the destmactive nature of the disease.

Indiara, Centerville - from Elien Ranch.

Collections of this fungus were made in May, July and August, 1923 at Walton, New York on both shade and forest trees. The disease was present on practically all of the trees examined.

This disease has also been found on earlier collections of maple leaves from three other states:

Michigan, Michigan Agricultural College, Lansing, July 7, 1894. Georgia, Gap of Dick's Ridge, Whitfield County, July 27, 1900. Missouri; Galena, Stone County, May 25, 1914.

Naple, $\mathbf{s}$ ilver (Acer dasycarpum) $=$ (台. Saccharinum)

Michigan, Michigan Agricultural College, Iansing - determined from specimens collected by C. F. Wheeler, June 2, 1897. Maple, Black (ficer rigrum)

Ohio, Antioch, Antioch College - determined from specimen received from 0. L. Inman, June, 1922.

Maple, Red (Acer rubrum)

New York, Waltor - collected on young trees, August 1, 1925. Alabama, Notasulga - collected by George W. Carver, April 29, 1897.

North Carolina - F. Sherman Jr., May, 1901.

No record of Exoascaceae on any of the maples listed above has been

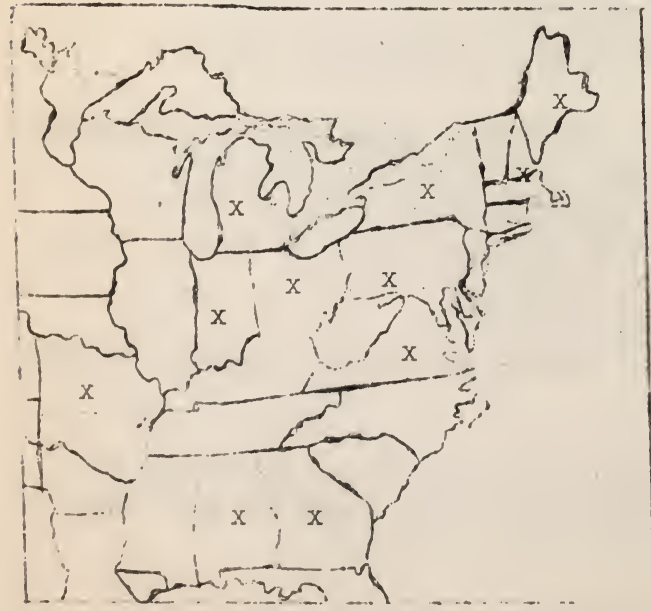

Fig. 15. Distribution of Taphrina spp. on Acer spp. found. The Taphrina spp. on sugar maple and on black maple are identical. This species is very similar to Taphrina Ecericola Massal. on Acer campestre from Italy ard further study may reveal that they are the same. The species on silver and red maples are of two undescribed species; as far as known.

The following are the only two species'described as vccurring in America:

Taphrina lethifer (Pk.) Sacc. on Acer spicatum; specimens collected by

C. H. Peck at Elizabethtown, Essex County, New York, June 1886.

Exoascus aceris Dearn. \& Barth. on Acer grandidentatum, Parley's Canon, Salt Irike County, Utah, 
June 29, 1915. (Fung. Col. E. Barth. 5018). A specimen ulso on leer grandidentatum from Bear Lake, Utah, July 6, 1908, collected by L. H. Pammel has been examined during the present study and found to be of this latter species.

The studies' of the hmerican Exoascesu on hcer spp. are being continued and will be reported in detail in a subsequent paper. The accompanying map (Fig. 15) summarizes tho distribution of Tiphrina spp. on icer spp.

Wilt caused by Verticillium sp.

"This disease was either noted or spocimens received from North Carolina, Tennessee, West Virginia, Virginia, Maryland, Pennsylvania, District of Columbia, Connecticut, New York, Indiane and Wisconsin during 1923. It has been found in one nursery and if careful inspections were made of nurseries for this disease; it woula probably bo found in a number of nurseries. On nursory trees as woll ks on shade trees it is very difficult to detect the disease until some part of the tree or even the entire tree wilts." (G. F. Gravatt)

Flyspeck - caiuse undetermined

+Hew York - along each side of Laborador Lake; Onondaga County, May 19. (Chupp)

Chlorosis caused by too much Iime.

Texas - (Taubenhaus)

Scorch caused by heat and drought.

Massachusetts - rather serious; much more than usual due to

drought conditions throughut summer. (Osmun)

Connecticut - throe reports. (Clinton)

New York - very important; stateyide; in severe cases caused defoliation.' (Chupp)

Indiana - reported from six countiss. (Gardner)

Frost injury due to weather conditions.

Ohio - throughout state; the scvere freeze of May 10 killed the leaves or seriously injurod those in the bud. (Detmers)

Illinois - a great many complaints have been roceived concerning the leaf injury to maples during the spring; at Peoria, Springfield and Galesburg this was manifested by a dead area on the petiole about one inch bel w the blade; the area was localized, being ab sut $3 \mathrm{~mm}$. in length; in other cases the edges of the leaves were brown; caused by cold high winds on May 7 and 8 when snow fell in many localities. (Anders on)

Winter injury

Ohio-caused splitting of bark; throughout northern half of statu. (Detmers)

OAK, POISON - SEe Sumac Puison

OAK, WHITE (Quercus alba) - See Canker, Quercus spp.

OAK, SWAMP WHTTE (quercus bicolor)

+Anthrachose caused by Gnomonia veneta (Sacc. \& Speg.) Klub. Now York - supposed tu be a new.host for state; Nassau County, June 10. (Chupp)

OAK, SCARIET (Quercus coccinea)

Rust caus $\Leftrightarrow d b_{i}$ Cronartium fusiforme (Pk.) Hedgo. \& Hunt. 
+Ohio - abundunt Iocally; state forest, soioto County, September 25. (Detmers)

OAK, WATTR (querous nigra) - See Oak - Leaf curl, Querous spp.

OAK, PIN (Quercus palustris) See Oak - Canker, Que rcus spp.

OAK, FINGLISH (Quercus robur)

Polyporus rubriporus Quelet

Recent literature:

Costantin, J. and L. Dufour. Une maladie secondaire du Chêne causee par le Polyporus (Phellinus) rubriporus. (The secundary disease of oaks caused by Pulyporus rubiporus). Compt. Rend . Acad. Sci. Paris 177: 806-809.

OAK, COMNOIN RED (Querous rubra)

Leaf blister caused by Taphrina coerulescens (Mont. \& Desm. ) Tul.

New York - Riverhead, Suffolk C.unty, June 12; collected by

Fernow. (Dept. Pl. Path.). Prior reports: Alabama, *Georgia,

Iowa, New Hampshire and *New York.

OAK, BIfCK (Querous velutina)

+Heart rot caused by Polyporus gilvus Schw.

New York - the majority of black oaks along Cascadilla Gorge

(Ithaca, Tompkins County) both above and below College

Avenue Bridge are dying or badly affected apparently from

this fungus; the black jaks on the campus are also affected;

the white. ocks show no injury. (Chupp)

Leaf curl - See Oak, Quercus spp.

OHK (Quercus spp.)

Mushroom root rot caused by Armillaria mellea (Vahl.) Quel.

+Delaware - very prevalent in Brandywine Park, Brandywine, New Castle Ciunty. (Adems)

+Wisconsin - it one place in Walworth County an acre of new growth was killed; it is undouptedly throughout tho hard wood regions of the state; it is mostly on smaller roots at some distance from the trunk. (six feet); in advance cases rot occurs at crown and up under the bark; Armillaria mellea is probably the cause of the rot, at least it is apporently so, as it is always present. Notes from R. H. Culley. (Vaughan)

Prior reports: California, Massachusetts, Minnessta, Oregon and Washingtun.

Anthracnose caused by Gnomonia veneta (Sacc. \& Speg.) Kleb.

Massachusetts - general throughout state; not serious th is year.

(Osmun)

+Florida - caused considerable spotting of leaves s ome of which are shed; not serious. (iteber). Prior reports: C onnecticut, Delaware, *District of C.Jumbia, Ge orgia, *Indiana, Iowa, Massachusetts, Michigan, Minnesutu, New Jersey, *New York, Ohio and Wisconsin.

Powdery ildew caused by Microsphacra alni var. extensu (Cke. \& Fk.) Salm.

Now Yurk - Quercus (rubra?), Enfield G orge, Tumpkins Cunty, July 4. (Chupp) 
Stem canker caused by Myxusn urium sp.

Connecticut - this fungus was found on cankers of living twigs, but the parasitic mature not proved by inoculation. (clinton)

Prior report: hIaska.

+Leafspot caused by Phyllosticta quercus Sacc. a Speg.

New York - Enficid Gorge, Tompkins County, July 4. (Chupp)

Heart rot of root and trunk caused by Polyorus sprasuei Berk.

Recent literature:

Weir, James R. PJyporus spraguei Berk., cause of heart rot. Phyt jpath. 13: 288. 1923. Hosts infected were Quercus rubru, Q. prunus, Q. coccinea, Q. velutina, Q. and Castanea dentata.

Canker caused by StrumeIla coryneoldea Sacc. \& Wint.

C onnecticut - xccasionally found on trees in woods; sometimes

break off at cankers; +Quercus alba and +Quercus palustris

hosts infected; Orange Cunty, Apri1. (clinton).

Prior report: Connecticut.

Leaf blister caused by Taphrina coerulescens (Mont. \& Desm.) Tul.

Connecticut - Storrs, New Heven County, July 28. (Clinton)

*New York - on Quercus velutina; Nassau Cunty, June 9. (Chupp)

*S suth Caralina - Greer, Greenville Cunty, July 4. (Iudwig). On

Q. nigra; Lynchburg, Ma 15. Cullected by E. D. Smith.

(Jenkins)

Georgia - specimens received from several puints in the state. (McHatton)

Florida - has caused considerable damaje to water oaks Quercus nigra) in Pensacjla and St. Augustine; large trees were almost completely defoliated and the situation was indeed alarming; collected als $)$ at Gainesville but not of such a serious nature there. (Weber)

Alabama - general on host in forests and fields; caused anxiety in some cases by defjliating the water jak (Quercus nigra) grown for shade. (Miles)

Mississippi - Clarke County, May 22. (Neal \& Barker)

Ohio - (A. E. Gravatt). Prior repurts: *hlabama, Connecticut, *Delaware, * Forida, *Ge orgia, IJwa, *Massachusetts, *Mississippi,

New Jursey, New York, North Carolina, Ohio, Oklah ma, Pennsylvania, Suth Carolina, *Texas and Virginia.

Recent literature on jak diseases:

Grintecu, J. Sur l'Jidium du Chêne et ses périthéces. (The Oidium of the oak and its perithecia). Bul. Soc. Stinte Cluj, 13: 497-505. 1923.

Marie, P. Note complémentaire relative a une recente communication sur les effets néfastes de la secheresse de 1921 produits sur les chênes de certaines régions. (The injurious results. of the dry summer of 1921 on oaks in some parts of France). Rev. Path. Vég. et Entiomıl. Augr. 10: 76-77. 1923.

Petri, Lionello. Sur la formation des chlamydospores chez l'0idium des chêes. (Formation of chlamydospores in the Oidium in Jaks). Cungres. Path. Vég. Strasbourg. 36-37. Imprimerie Alsacienne: Strasburg. 1923.

Portal, M. The defoliation of Jaks. Country Life 54: 124-126. JuIy 1923.

Vanine, E. La purriture annulaire du chêne, pr sduite par le Vuillemina comedens Maire. (Annular rot of oak caused by $\underline{V}$. 
cumedens). Rept. Inturnat. Conf. Phytopeth. and Econ, Fntomol. Holland 11: 263-264. 1923.

Williamson, Helon Stuart. The origin of 'Gulden Oak.' Ann. Bot. 37: 433-444. 1923 .

PEPPER TREE, CALIFORNİं (Schinüs mulle)

+ Timber rot caused by Inonotus schini Brown

Arizuna - causes rot of timber, a wilt and death of trees; Tucson, Pima Cuunty, July 16. (Br Jwn)

PLIN, HMERICAN (Prunus americara)

Brom rot caused by Scler otinia cinerea (B on.) Schruet.

+New York - Tompkins C sunty, May 15. (Chupp). Fund on five varieties of this specius causing fruit $r$ t. (Kirby)

Prior report: *Mississippi.

Leaf scorch caused by weather

New York - in park at Ruchester, Monrue Cunty, September 21. (Chupp)

PLUM, HORTULAN (Prunus hortulana)

+ Brow rot caused by Sclerutinia cinerea (Bun.) Schroet.

New York - found on two varieties of this species causing fruit rot; Tompkins Cuunty, October 9. (Kirby)

PLUM, WIDGOOSF (Prunus muns uniana)

+Brown rot caused by Sclerotinia cinerea (Bon.) Schroet.

New Y ork - found on five varicties, Downing, Froestone, Gooso,

Newman and Arkansas; Tomphins Cunty, Octuber 9. (Kirby)

PLUM, ChNADA (Prunus nisra).

+ Brow rot causcd by Sclerotinia cinerea (Bon.) Schroet.

New York - fruit rot on variety Cheney; Tompkins Cunty, Ontober 9. (chupp)

PLUM, JAPINESF (Prunus salicina)

+Brown rot ceusod by Sclorotinia cinerea (Bon.) Schroet.

New York - found on six varieties, Red June, Ontober, Osjon, Abundarce, Burbank and Chabot, Tompkins Cunty, Ontuber 9. (Kirby)

POPLAR, SILVTR (Populus alba nivea)

+ Cinker causod by Duthichiza populea Sacc. \& Br.

Connecticut - Fairficld (tw) reports) and Nuw Haven (three reports) Cunties. Reports are from Entomological Nursery Inspections. (Zappo)

POPLAR, SOUTHERI COTTONYOOD (P Jpulus deltuides)

Rust caused by Melampsora modusae Thuom.

How York - Tompkins C unty, Septembur 14; pori dd of greatest injury was in September. (Chupp). Prior ruports: *Illinjis, *Indiana, Iowa, *Mississippi, North Dikuta, Oklahoma, *Texas, *West Virginia and *Wiscounsin.

POPLAR, CiROLINh (Pupulus eugenei) + Cankur cousud by Cytospora chrys jsperma (Pors.) Fr. 
Ohio - a surius invasion in a blok of cerjina poplars on a plantation near Chillicothe, Ross Cunty, June 15. Only report received su far of this disense in Ohio. (Dutmers)

Canker caused by Duthiohizi puoulca Sanc. \& $3 r$.

+Connecticut - Firfield (Ridëefield, September 6) and Midalesex Countios. (Zappe). Prior report: Ohio.

Recent litorature:

Detmers, Freda. Dothichiza canker on Norwa poplar. Phytopath. 8: $245-247 \cdot 1923$.

POPLIR, IOMBRDY (PJpulus nigra italica)

Canker caused by Dothichiza pupulea Sacc. \& Br.

tConncticut - thirty-fur reports (from all counties except Tulland);

chiefly ir mo nursery inspecturs; first report from New Haven,

Niew Huven Cunty, éune 20.

New York - Bronx Gardens, New York, Bronx County, May 11. (Chupp)

+Maryland - (Hahn)

+Indina - twigs and branches girdlod and killed; Lafayette, Tippecarve Cunty, Nay 27. (Gardnor)

Prior reports: *Illinois, *New York, Pennsylvania and Wisconsin.

Recent litercture:

inonymous. Tur pean black canker (Dothichiza populea).

Tree Talk 3: 23. . 1923:

+Yellow Ieaf blister caused by Taphrina aurea Fr.

Oreg on - rosulted in little, if any, injury to the host; Eugene, Lane County, June 19. (B syce)

ASPEN, QUAKING (Populus tremuloides)

Canker causud by Cytuspora chrysospermi (Purs.) Fr.

+Minnesota - sevoral clumps of trees in Ramsey County found dead or dying on June 3. (Sect. PI. Path.)

Prior reports: Arizona, *Colorado, Idaho, Montana, New Mexico,

*New York; North Dakota, *Pennsyllvania, Suth Dakota, Utah

and *Wyoming.

Liypoxylon canker caused by Hypoxylon pruinutum (Klotsch) Cke.

Recent literature:

Povah, ilfred. Hypoxylon poplar canker. (mbstract) Phytopath.

12: 59. 1922. Cites disuase fuund in Mine, New York and Michigan.

+ Ter spot caused by Rhytisma sp.

Minnesute - (Sect. Pl. Páth.)

POPLAR (Populus spp.)

* Apiosporium salicinum (Pers.) Kzo.

New York - Suffolk C ounty, August 19. (Chupp)

Canker caused by Cytospors sp.

New Mexics - common. (Crawfora)

Washinzton - Grant Cunty. (Heald \& Dana)

Canker caused by Cytospora chrys spiorm (Pers.) Fr.

North Dakota - important in nurseries. (Weniger)

New Mexics - Lumbardy very suscentible; appears to attack trees

that are weakened in some way, as toj little water or improp-

erly pruned; State College, D sna Ana County, July. (Crawford)

Arizona - scattered over the, state. (Brown) 
Canker caused by Duthichiz: populea Sacc. \& Br.

Massachusetts - common. (Osmun), (D:ivis)

Ohiu - severe lonally, Ross County. (Detmers)

Minnes uta - Beltrami Cuunty. (Sect. Pl. Path.)

Leafspot caused by Marss onia populi (Lib.) Succ.

+Colorado - lonal; Fort Cullins, Larimer Cunty, September. (Learn)

Pri or reports: Maryland, Massachusetts, New Hampshire and New Jersey.

Rust caused by Melampsora larici-p jpulina Kleb.

+oklahoma - Payne County, October 29. (Stratton)

+New Mexico - Dona ina C sunty. (" rawford)

Prior reports: ${ }^{*}$ Conn cticut, Iowa, Luuisiana, Kansas, Maine,

*Maryland, *Massarhusetts, Minnesuta, *Nebraska, New Jersey, New Mexics, *Now York, North Dakota, Oklahoma,*Virginia, Washington and West Virginia.

+Rost rot caised by Ozonium omnivorum Shear

Texis - prevalont; 1\% reduction. (Taubenhaus)

+Mistlotoe - Phorsdendron flavescens (Pursh) Nutt.

New Mexico - common; very important; one of the chief causes for death of oottunwods in the Mesilla Valley; very few trees free from infestation. (Crawford)

Hail injury

Pennsulvania - (Hahn)

Recent literature:

Foëx, E. Une maladie du Peuplier. (h discase of the Poplar). Rev. Hort. 95: 476-477. 1923.

Hiley, W. E. Fungus and bacterial disuases of Poplars. Great Britain For ost. Comm. Bul. 5: 47-50. 1923.

PRUNUS, AMPRIChIN - See Plum, Common Wild, also Brown Rot, Prunus spp.

PRUNUS, LINGUSTIFOLIA WHTSONI - See Frunus spp., Brown Rot

PRUNUS, CERTiSIFTRi- See Prunus spp., Brown Rot

PRUNUS, DEMISS $\mathrm{r}_{\mathrm{r}}$ - See Cherry, Western Choke

PRUNUS, DUNB

PRUNUS, GLANDULOS: - See $\leadsto$ Inond, Flowering

PRUNUS, HORTULAN - See Plum, Hortulan

PRUNUS, MARITIMA - See Frunus spp., Brown Rot

PRUNUS, MUNSONIniNi - See Plum, Nild Guoso

PRUNUS, NIGRì - See Plum, Canada

PRUNUS, ORTHOSEPhLi - See Prunus spp, , Br swn Rot

PRUNUS, PENNSYLVANICA - See Cherry, Pin

ERUNUS, SALICINÁ - See Plum, Cherry

PRUNUS, STROTINA - See Cherry, Black 
PRUNUS, WATSOHT -.See Prunus spp.

PRUNUS, VIRGINIANA.- See Cherry, Common Choke

PRUNUS SPP.

Brown rot caused by Sclerotinia cinerea (Bon.) Schroet.

New York - Kirby and Honey surveyed a park at Rochester, Monroe

County, September 2l, obtaining the following data:

Species Amount of rot

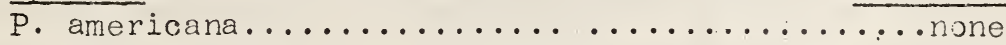

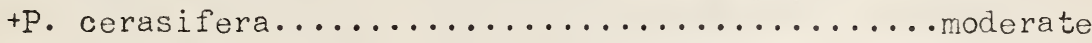

+Hybrid of P. dunbarii, maritima and americana...heavy

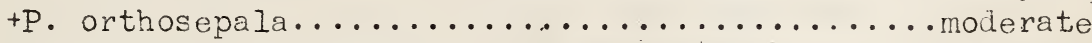

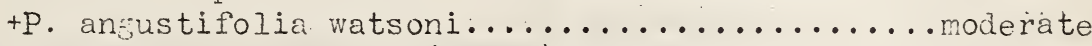

(Chupp)

PYRUS SPP.

Fire blight caused by Bacillus amylovorus (Burr.) Trev.

New York - in a park'survey made by Kirby and Honey at Rochester, Monroe County, September 22, the following data was obtained: Species

+ P. betulaefolia (Birch leaf pear)........very heavy

+ P. canescens $\quad \ldots \ldots \ldots \ldots \ldots \ldots \ldots$. . . . . . . . . . .

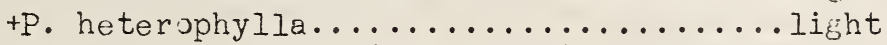

+ P. Serotina culta (late pear)..........trace

(Chupp).

REDBUD (Cernis sp.)

* Leafspot caused by Ovularia cercidis S. Cam.

Missouri - appeárs to be scatțered and inconspicuous; Osage City, Cole County. (Burrill)

REDWOOD (Sequoia sempervirens)

Albino

Recent literature:

Anonymous. Albino redwood shoots. Missouri Bot. Gard. Bul. 11: $90-92$. 1923 .

SASSAFRAS. (Sassafras variifolium)

Nummularia microplaca B. \& C.

*+North Carolina - Cashiers, Jackson County, Ontober 5. Collected

by. George H. Hedgecock. Prior reports: *Onio and *Virginia.

Leafspot caused by Pestalozzia sp.

+New York - Monroe County, September 21. (Chupp)

SUMAC, SMOOTH (Rhus glabra).

Leafspot causec by Cercospora rhoina Che. \& Ell.

*+Missouri - one of the worst attacks seen; Jefferson City, Cole

County, July 29. (Burrili). Prior reports: Alabama, *Dis-

trict of Columbia, *Indiana, *Kansas, *Mississippi, *Nebraska, New Jersey and *Virginia

SUMAC, POISON IVY OR OAK (Rhus toxicodendron)

Rust caused by Uromyces toxicodendri Berk. \& Rav. 
*+New York - Suffolk County, June 2l. (Jhupp). Prior reports: *Arkansas, *Connecticut, *Illinois, *Indiana, *Iowa, *Kansas, * Louisiana, *Massachusetts, *Michigan, *Minnesota, *Mississippi, *Missouri, *Nebraska, *North Dakota, *Ohio, *South Carolina, *Tennessee, *Texas, *Vermont, *Virginia and *Wisconsin.

SUMAC, STAGHORN (Rhuis typhina)

+Canker caused by Physalospor a cydoniae Arnaud

New York - Chautauqua County, Jine 25. Collected by Kirby and Honey. (Chupp)

SYCAMORE (Platanus occidentalis)

+ Leafspot caused by Cercospora sp.

Louisiana - common but not important; Baton Rouge, East Baton Rouge Courty, July. (Edgerton)

Anthracnose caused by Gnomonia veneta (Sacc. \& Speg.') Kleb.

Niassachusetts - serious locally. (Osmun)

New York - ommon everywhere; Nassau County, June 10. (Chupp)

Delaware - more prevalent than usual; Newark, New Castle County, May 29. (Adams)

Pennsy Ivania - heavy infections. (Hahn)

Alabama - general; some trees killed by repeated attacks. (Miles)

Ohio - seemed tu be more prevalent and serious than usual in June. (Detmers)

Indiana - severe. (A. E. Gravatt)

Michigan - severe: (A. F. Gravatt)

Iowa - less than 1922. (Melhus)

Missouri - Callaway County. (Burrill). Prior reports: Alabama, Connecticut, Delaware, *District of Columbia, *Illinois, Indiana, Iowa, *Kansas, *Maryland, Massachusetts, Michigan, *Missouri, *New York, *Ohio, *Pennsylvania, *'lexas and West Virginia.

Leafspot caused by Stigmina platani (Fckl.) Sacc.

* Missouri - two collections made at Columbia which seem to be the first made there. (Maneval). Prior reports: *Arkansas, *California, *Georgia, *Illinois, *Miss issippi, *Oklahoma and *West Virginia.

Canker probably due to winter killing

Wisconsin - cankers mostly on south side of young trees; Waterloo, Jefferson County, June 30.' (Vaughan)

WALNUT, B LACK (Jug laris nigra)

Anthraenose causeà by Gnomonia leptostyla (Fr.) Ces. \& DeNot. (Marssonia juglandis (Lib.) Sacc.)

New York - defoliates most of the trees in the state. (Chupp)

* Minnesota - "Iright County. (Sect. Pl. Path.) Prior reports: Alabama, *Arkansas, Connecticut, *Delaware, *Illinois, Indiana, Iowa, *Kansás; *Maryland, *Michigun, *Nebraska, New Jersey, North Daksta, Pennsylvania, *South Carolina, *Virginia, West Virginia and Wisconsin. 
New York - reported on Salix nigra; Onondago County, September

I5. (Chupp)

Rust caused by Melampsora bigelowii Thuem.

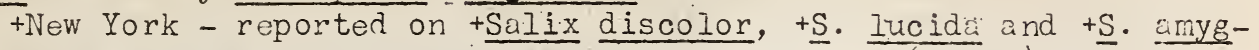
daloides, Tompkins County, September 2. (Chupp)

Minnesota - Itasca County. (Sect. Pl. Path.)

Orezon - abundant; Homestead Inn, Hood River County. (Boyce)

Prior reports: *Colorado, Connecticut, Idaho, *Illinois, *Indiana, Iowa, *Kansus, *Michigan, Minnesota, *Montana, *Oregon,

*Pennsylvania, *Tennessee, Texas, *Virginia, *Washington,

West Virginia and *Wyoming.

Rust caused by Melampsora larici-capraearum Kleb. 'M. Salicis caprae wint.)

+Okluhome - Payne County, October 25. (Stratton)

Prior reports: Minnesota, Montana and Ohio:

Powdery mildew caused by Uncinula salicis (DC.). Wint.

New York: - probably statewide; Tompkins County, August 18. (Chupp)

Iowa - (MeIhus)

Oregon - abundant and sometimes caused premature leaf fall; Port-

land, MuItnomah County, October 28. (Boyce). Prior reports:

Connecticut, *Illinois, *Indiana, *Iowa, *Maine, Maryland,

Massachusetts, *Michigan, *Minnesota, *Mississippi, *Montana,

*New Hampshire, *New York, *North Dakota, *Ohio, *Oregon,

*Vermont, *Virginia, Weshington and *Visconsin.

Canker - cause urdetermined.

Connecticut - similar to Furopean canker but microscopical examination failed to verify the cause. (Clinton)

Flyspeck - 0:use undetermined

New Yur'k - reported on Salix discolor; Onondago County, September 10. (Cinp)

\section{WOOD DESTROY ING FUNGI}

Wood rot caused by Polypoms schweinitzii Fr.

Minnesota - saprophytic on trunks of Picea mariana and Pinus resinosa and on the roots of pinus divaricata. (Sect. Pl. Path.)

Wood rot caused by Polyporus anceps Pk.

Minnesota - very common wood rot of conifers. (Scct. PI. Path.)

Rot caused by Poria incrassata (B. \& C.) Burt.

Florida - during the past year tho Plant pathologist was called

to St. Petersburg where a lumber company roported the loss

of thousands of dollars worti of lumber because of a

fungous organism which causes rot to timber. The fungus

Poria incrassatal was found very prevalent in all parts of

the large shed where it was destroying sawed boards, floor-

ing, piles, joints, window-frames and building paper. To

control this disease it was neceśsary to resaw all the

lumber, put in a new concrete floor and thoroughly disinfect

the entire establishment. (Weber)

Recent literature:

Humphrey, C. J. The destruction by the fungus."Poria incrassata" of coniferous timber in storage and when used in the construction of buildings. So. Lumb. Jour. 49: 36-37, 49-53. Feb. 1923. 
Decay of lumber and building timbers due to Poria incrassata (B. \& C.) Burt. Mycologia 15: 258277. Nov. 1923.

The destruction by the fungus "Poria incrassata" of coniferous timber in storage and when used in the construction of buildings. Proc. Amer. Wood. Preser. Assoc. 19: 188-207. 1923.

HOUSE AND FURNITURE

Dry rot ciused by Merulius lacrymans Fr.

Connecticut - one report from Wallingford, New Haven County, August. (Graves).

\section{CONIFFROUS SEEDLINGS}

Damping-off caused by Rhizoctonia solani Kuhn

Connecticut - isolated patches of seedlings here and there at Cheshire, New Haven County, were killed of white and red. pines also white and blue spruce, July $7 \cdot$ (Clinton)

\section{Recent literature:}

Aullo, M. Resena fitopatologica forestal. (A survey of forest phytopathology in Spain). Rev. Fitopatologia. (Madrid) 1: 9-II. 1923.

Bateman, T., and C. Herningsen. Theory of the mechanism of protection of wood by preservatives. Experiments with hydrocarbons. Proc. Amer. Wood Preservers' Assoc. 19: 136-144. 1923. Boyce, J.S. Decays and discolorations in airplane woods. U. S. Dept. Agr. Bul. 1128: 51. 1923.

Chavastelon, R. Sur un procede de conservation des bois. (On process for the preservation of wool). Compt. Rend. Acad. Sci. Puris 176: 1178-1179. 1923.

Cutler, N. I. A contribution to the knowledge of the tree destroying fungi of the Vancouver forestry district. (Abstract) Phitupath. 8: 294. 1923.

Dodge, A.W. Diagnosing shade tree diseases. Tree Talk. 53: 7-9, 30. 1923.

Doé, Fr. L'öidium et le traitement des forests feuillues du nordest de la Frande. Rev. Eaux et For. 61: 429-436. Oct. 1923.

Gerry, Eloise. Five molds and their penetration into wood. Jour. Agr. Res. 26: 219-230. 1923.

Haasis, F. T. Root rot as a factor in survival. Amer. Jour. of Forestry 21: 506. 1923.

Hammarlund, Carl. Boletus elegans Schum. und Larix-mykorrhiza. Bot. Not. 4: 305-326. 1923.

Jennings, 0 . E. The relation of smoke, fumes and dust to the vegetation of the industrial district of Pittsburgh. Trillia. 7: 27-38. Oct. 1923 .

Hansen, T. S., W. H. Kenety, G. H. Wiggin, and E. C. Stakman. A study of the damping-off disease of coniferous seedlings. Minnesota Agr. Exp. Sta. Tech. Bul. 15: 35. Apr. 1923.

Harvey, R. B. Cambial temperatures of trees in winter and their relation to sun scald. Ecology 4: 261-265. July 1923.

Humphrey, C. J. Decay of poles and the fungi which cause it. Rept. Special Comm. on Wood Preservation. Amer. Flectric Railway Engincering Assoc. 312: 52-69. mer. Elec. Railway Assoc. New York. 1923. 
Korstian, C. F. Control of snow molding in coniferous nursery stock. Jour. Agr. Res:. 24: 747. June 1923.

Laubert, R. Ueber bosonders heftiges suftreten einiger Fruhjahrskrankheiten von Ziergeholzen in Jahro 1923. "The purticularly sevire occurrcnce of some spring disevises of ornamontal trees in the year 1923). Gartenwelt., 27: 222-224. 1923.

M , F. i. The decay of structural timber, its oauses and prevention. Bul.. Bur. Biotechn. Luods. 2: 7-20. Mar. 1923.

Rathbun, Annie E. Damping-off of, taproots of Conifers. Phytopath. 8: 385-390. 1923 .

Rhoads, A. S. Tho formation and pathological anatomy of frost rings in conifers injured by Iate frosts. U. S, Dept. Agr. Bul. 1131: 1-15. Feb. 19.23.

Richards, C. nudrey. Methods of testing the relative toxicity of wood preservatives. Proc. Amer. Wood Preservers' Assoc. 19: $127-135$. 1923.

Rogers, W. E. Resistance of trees to ice storm injury. Torreya. 23: 95-99. Nov. - Dec. 1923 .

Schmitz, H. Notes on wod decay. The wood destroying properties of Polyporus volvatus. Amer. Jour. of Forestry, 21: 502-503. $192 \overline{3}$.

Studics in wood decay. Physiological specinlization in Fomes pinicola Fr. (Abstract) Phytopath. 13: 511. 1923.

Sharples, A. Final report on treatment of mouldy rot disease. with agrisol. Maliyan Agr. Jour. 11: 36-37. Feb. 1923.

Snell, i. IH. The effect of heat upon the mycolium of certain structural timber-destroying fungi within wood. Amer. Jour. of Botany 10: 399-412. 1923 .

The efiect of hoat upon wood destroying fungi in mills. Proc. hmer. Wood. Preservers' issoc. 18: 25-32. 1922.

Soule, Roland P. Low temperature tars and wood preservation. Proc. Amer. 'lood Preservers' Assoc. 19: 114-127. 1923.

Stakman, E. C. Fungi causing damping-off of coniforous seedlings in Minnesota. Minnesota Sta. Tech. Buil. 15: 29-35. 1923.

Toumey, J.W., and Ernest J. Neethling. Some effucts of nover over coniferous seedbeds in southern New Fngland. Yale Univ. School of Forest. Bul.9: 1-39. 1923.

Vanin, S. T. Pests of forest trees in the aifferent plantations of the Romanoff Forestry Area of the goverrmont of Tamboff in 1918. 'Plant discases', Jour. Centr. Phytop.th. Stat. Chief Bot. Gard. Russian Republic 11: 9-23. 1922.

Vanine, E. Esși d'valuation des pertes causées forestieres auxé aspeces par les champignons parasites. (Losses saused by parrsitic fungi on for est trues). Rept. Internat. Conf. Phytopath. and Eoon. Entomol. Holland 258-262. 1923. Le Hydnum septentrionale, perisite des arbres"a feuilles. (H. soptentrionale, parasitic on deciduous trees). Rept. Internat. Conf. Phytopath. and Foon. Entumol. Holland, 264-267. 1923.

Van Luyk, A. Ueber einige Sphaeropsidecte und Melanconieae auf Nadelhölzern. (Notes on some Sphaeropsideae and Melunnomieae on Conifers). Ann. Mycol. 21: 1-2. 1922.

Vaughan, Ira. Sick trees saved. Tree Talk. 5: 14-18. 1923. 
Weir, J. R. Fomes roseus (A. \& S.) Cke. and Trametes subrosea nom, novum. Rhodora. 25: 214-220. Dec. 1923. Polyporus sprague.i Berk., cause of heart rot. Phytopath. 8: 288. 1923 .

The genus Polystictus and decáy of living trees.

Phytopath. 8: 288. 1923.

The effect of broadcast burning of sale areas on the growth of cull-producine fungi. Jour. of Forestry 21: 183-184. 1923. Review of Applied Myc logy, Impurial Bureau of Mycology 2: 529-592. Dec. 1923 .

Anonymous. Current topics. Nature 111: 679. 1923. The director of the Botanic Gardens at Kew has called the attention of the House of Commons to the damege likely to result from smoke. "There can be no doubt that heavy deposits of soot such as are borne by the evergreens at kew are clear indication of atmospheric contamination which will markedly lower the vitality of the plants in the Gardens and in some cases may actually provent their successful a ltivation." ft present the greatest danage probably arises from reduction of light.

\section{DISFASFS OF ORNAMFNTALS}

AMPELOPSIŚ or VIRGINIA CRESPER (Ampelopsis quinquefolia)

+Leafspot caused by Pestalozzia sp.

Florida - caused partial defoliation and stunting of vines in vicinity of Gainesville. (Webor)

Powdery mildew caused by Uncinula necator (Schw.) Burr.

New York - Wyoming County, August 24. Collected by E. F. Guba. (Chupp)

Nelaware - observed locally and usually prevalent as the mildew on lilac. (Adams)

Prior reports: *Colorado, Connecticut, Deleware, *Distriot of Columbia, *Illinois, *Indiana, Iowa, *Kansas, Maryland, *Massachusetts, Minnesota, Missouri, *Nebraska, *New Jersey, *New York, *North Dakota, *Ohio, *South Dakota, *Vermont and West Virginia.

AMPELOPSIS (hrmpelopsis spp.)

Leafspot caused by Guignardia bidwellii (EII.) Viala \& Ravaz.

Has been found on fmpelops is quinquefolia and fmpelopsis tricuspidata in Connecticut, *Delaware, Distriot of Columbia, Illinois, Indiana, Iowe, *Kansas, Maryland, Massachusetts, Minnesota, Iubruska, New Jersey, *New York, * North Carolina, North Dikota, Ohio, Pennsylvania, Rhode Island, Texas, *Vịg inia and. West Virginii.

\section{ASPARAGUS FFRIJ (Asparagus plumosus)}

Blizht caused by Fusarium sp.

Florida - important; nature of injury is a blighting and shedding of leaves, sltamonte Springs, Seminole.County, September 1. (Foster)

Phome sp.

Florida - occasionally reported to be very severe in nurseries. (Weber) 
ASPIDISTRA (Aspidistra sp.)

Leafspot caused by colletotrichum omnivorum Halst.

+Missouri - found in the greenhouse of the horticultural department of the College of $A_{0}$ riculture, Columbia, Boune County. (Maneval). Prior report: *Pennsylvania.

ASTER (Callistephus chinensis)

Wilt causod by Fusarium conilutinana var. callistephi Beach

Nell York - very important causine a.I to 3\% reduction in yield; us $h i_{\text {s }} \mathrm{h}$ as $25 \%$ infection iound in inaividual plots; probably statewide in distribution; probably same as was described in Ohio as Fusarium incarnatum Wallenw., at least the symptoms are the same. (Chupp)

Illinois - less than previous year; important wherever it occurs; about $5 \%$ of plantings in state are affected; $1 \%$ reduction in yield, Bureau and Tazewell Counties. (Tehon)

Michigan - Niles, Ber:ien County, June 28. (Coons)

Minnesota - severe in some fields and greenhouses in Ramsey County. (Sect. P1. Path.)

North Dakota - common in eastern and central parts; probably general over. state; a limiting fantor in asters growing in garden plots, Coliate, Steele County, August 6. (Weniger)

+Kansas - Topoka, Shawnee County, furust 1 (Stokdyk); Ramsey, Riley and Shawnee County. (inite):

Prior reports: Idøho, Illinois, Indiana, *Michigan, Minnesota, New Hampshire, New York, North Dakota, Ohio, Oreछon, Vermont, Washington and West Vir inia.

Wilt caused by Fusarium sp.

New Jersey - severe in some gardens, Atlantic City, ftlantic City County, July 11. (Sect. Pl. Path.)

Delaware - Wyoming, Kent County, kugust 29. (Adans)

Florida - vas very severe in isolated places in state. (Weber)

Indiana - Tippecanoc County. (Gardner)

Ohio - of considerable importance; about $90 \%$ of plantings in state were infected; early varieties most susceptible; Comet variety somewhat resistent; of general range throughout state; Delaware County, May 5. (Young)

Idaho - fairly common. (Hungerford)

Leafspot caused by Septoria callistephi Gloyer

New York - not important; a trace of Ioss, Cayuga County, June 10. In Monroe County, Newhall reports as follows:

"Abundant on 40 varieties in the seedbeds, quite severe, may be 15 to 20\%. Rein first week in June. Seed was known to have pycridia an it and was treated one-half hour in formaldehyde but seed of stors float and are hard to wet." (Chupp)

*+Ohio - Summit County, June 18. (Young).

-Prior reports: Illinuis, Michigan and *New York.

Leafspot caused by Septoria sp.

+Delaware-general in state; some plantings in home gardens showed severe defoliation, Wyoming, Kent County, August 29. (hdams)

Prio: report: *hlabama.

+Anthracnose caused by Colletotrichum sp.

Florida - was reported from Tampa, the only instance in the state. (Weber) 
Root knot caused by Heterodera radicicola (Greef.) Muell. +Washington - Pierce County. (Heald \& Dana).

Prior report: Connectiout.

Stem blight caused by Botrytis sp.

+Pennsylvania - Fayette County. (Thurston)

Prior report: Connecticut.

Mosaic cause unknown

+California - on occasional plunt, Sunta ina, Orance County,

September 3. (Harter \& Weimer). Prior report: Minnesuta.

Yellows cause unknown

New York - important locally, loss trace to $1 \%$; Honey and Kirby found one bed in Monroe County with 100\% infection;

Tompkins County, September 20. (Chupp)

Delaware - most importent disease affecting this plant; greater prevalence observed on the lighter types of soils; affected plants show retarded growth on sandy sọils, especially during drought poriods. (idams)

Washington - Pierce County. (Ilesld \& Dana)

Prior repurts: *California, Connecticut, Deleware, Idaho, Maine, *Maryland, Massnchusetts, Minneșta, New Hampshire, *New Jersey, New York, Pennsylvania, Rhode Island, Vermont, Virginia, Washington and. Wisconsin.

Recent literature:

Kunkel, L. 0. Insect transmission of aster yellows.

(Abstract) Phytopath. 14: 54. Jan. 1924.

Miscellaneous.

Recent literature:

Gloyer, $: 0$. Fungous diseases of the China aster. (1 bstract) Phytopath. 14: 64. Jan. 1924. Diseases eited are Ascochyta asteris (Phyllosticta asteris Bres.), Botrytis cinerea, c.leosporium solidaginis, Fusarium sp., Phytophthor sp., Rhizoctonia solani, and Septoria callistephi.

AZALEA (Azalea spp.)

+Dodder - Cuscutia sp.

South Carulina - on A. formosa; unimportant, Summerville, Dorchester County, October 15. (Iudwis)

Gall caused by Exobasidium azalcie Pk.

+Florida - one report, leaves infected. (Weber)

Prior report: hlabama.

Gall causcd by Exobasidium vaccinii (Fokl.) Wor.

+Louisiana - Baton Rjuge, East Baton Rouge County, May 8. (Fdgerton)

Prior reports: *hicibama, Connecticut, *Dis.trict of Columbia, *Gouryia, *Illinois, New üersey and *South Carolina.

Gall caused by Exobasidium sp.

South Carolina - Dorchester (Summerville, April 12) and Sumter

Counties. (Ludwig). Prior roport: Connecticut.

Powdery mildew eau sed by Microsphaera uni (Wallr.) Wint.

+New York - observed in a purk at Rochoster, Monrje Cunty,

Suptember 21 on the. following spcoius: ${ }^{+}$Azalea gandavensis

(this species most heavily infected), +h. moli is, + + .

pontica anci +A. esmeralda.

Prior report: Connecticut.

Damping-off nausc unknown

liassachusetts - (h. E. Gravent) 
BAMBOO

Bacterial leafspot cause undetermined

Florida - was very common on bamboo leaves; the plants became partially defoliated from the results of the discase. (Weber)

Rust caused by Puccinia melanocephala Syd.

Florida - reported from three different localities in the state exclusive of Jacksonville where it was collected in 1922; wherever it was collected the infection was quite general. (Wejer)

BARBRRY (Berberis spp.)

Leafspot caused by banteria

New:York - notes on barberry infection made by R. S. Kirby at Rochester, June 9. The following species showed from 2

t. $5 \%$ of the leaves infectea: Borberis amurensis japonica,

B. Sargentiana, B. subciuliata, B. thumbergi, B. verruculosa,

B. vulgaris, B. weichangens is and B. yunnanensis.

is ...Idaho - wherever Barberries are grown. (Hungerford)

Rust caused by Puccinia graminis Pers.

New York - Notes on barberry infection made by R. S. Kirby at Rochester, June 9. The various species are marked as

follows:

Trace (one or two infected leaves) on Berberis angulosa and $\underline{B}$. fendleri.

Light ( 4 or 5 leaves infeoted) on Berberis declinata oxyphulla, B. liechlinii, B. oblonga and $\underline{B}$. sinensis.

Moderate (2 to 5\% leaves infected) on Berberis alesuthensis, B. amurensis japonica, B. durobrivensis, B. emarginata,

B. Iuchsjidos, B. meihanii, and $\underline{B}$. subcauliata.

Heavy (over $15 \%$ of leaves infected) on Berberis amurensis, B. aristata, $\underline{B}$. canadensis and $\underline{B}$. emar inata britzensis.

Berberis vuluaris had over $90 \%$ leaves infected; infection fuund on nuarly every bush in state; Owego, Tioga County, May 6.

No infection on Berberis aggregata, B. brachypoda, B. breviEvirulats, E. buxifulia, B. concinna, B. coryi, B. cratasine, B. crataejoides, 3 . dasystachya, B. diäphana,

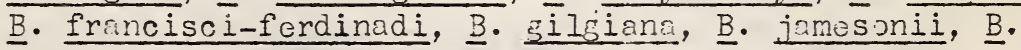
koreana, B. puireti, $\underline{B}$. pratti, $\underline{B} \cdot$ sargentiana, $\underline{B}$. serrata, ‥ Etenophzlia, B. swasey, B. thunbergi, B. virescens, B. wilsonae, $\underline{3}$. yumraronsis, Mahonia aquifolium and $\underline{M}$. repens.

BEGONIA (Begonia sp.)

Anthracnose caused by Glooosporium bejuniae Magn.

+Florida - resulted in a cmplete girding of the stem and col-

lapse of the plant; Palatka, Putnam County. (Weber)

Root knot caused by Heterudera radicirola (Greef.) Muell.

Ohio - galls formed on rusts; Champaign County, January 23.

(Detmers). Prior reports: Indiana and Nebraska.

BDRBRRIS SPP. - See Barberry

BOSTON IVY - See Ampclupsis tricuspidata 
BOX (Buxus sempervirens)

Leafsout caused by Macrophuma candol.Li (Brk. \& Br.) Berl. \& Vogl. New Jersey - Riverton, Bur lington County, September 15. (Dept.

Pl. Path.). Prior reports: *Distrint of Culumbia, Maryland,

*Mississippi, New Jersey, *Now York, *iorth Car Jlina, *Pennsylvaria, *Texas and *Virginia.

+Leafspot caused by Phyllosticta sp.

* New York - Mincola, Nassau County, kugust 6. (Chupp) B.likht cause unknown

liississippi - many hedges in state affected, causing the plant t. frequently die; apparently of general range; enlarged lenticels are quite noticeable; aisease possibly caused by excessive moisture or poor drainage; was reported May I from Forest $C$ sunty and was later reported from several sections of the state. (Neal-\& Barker)

BUDDLIA-See Butterflybush

BUTTERFLYBUSH (Buddleia sp.)

+Root knot caused by Heterudera radicic le (Greef.) Muell.

Mississippi - one report; serious; Tunica Cunty, April 27. (Neal \&. Barker)

CA LENDULA (Ca lendula sp.)

Rust caused by Puccinia recedens Syd.

*+Kansas - occurred in 1922 in the college green houses but was nut reported; it re-occurred during the winter of 1922-23 in

the same bench; determination made by J. C. Arthur; the rust has not been $f$ und outside of the greenhouse although Calendula plants have been examined in the neishborhoud. (White)

Prior report: Illinois.

Recent literature:

Perotti, R. and G. Zaffuts. Sui bacilli radicali della Calendula officinalis. L.) Rendic. Anad. Lincei 32: 94-98. 1923.

ChiLh (Zantedeschia sp.)

Leafspot caused by Cercospora callae Pk. \& Clint.

HNew York - Tampkins Cunty, August 11: Cullected by E. E. Honey.

(Chupp). Prior reports: *Massicliusetts and *Wisconsin

CAMELIA (Camellia japonica)

Leafspot caused by Postalozzia guepini Desm.

thlabums - runges through out southorn countios; sevore in a number of nurseries; in these cases the salability of the plants were recuced. (Miles). Prior reports: *Louisiana, *Mississippi, *iluw York and *Ponnsyliania.

CANNh (Canna indica)

+Rust causod by Pucrinia cannae (Wint.) P. Henn.

Florida - the rust was well scutterod joor tho plants, killing the older leaves, St. Petersbure, Pinellas County. (Wei or)

ChRNATION (Dianthus caryophyllus)

Alternariose caused by Alternaria dianthi Stev. \& Hall

Connecticut - one report; reported only onou before; the Enchantress Variety was s, badly injured that the crop in the 
şreenhouse was a partial failure, New Haven, New Haven

County, November 28. (Clinton)

Prior reports: Connecticut, Marylsind, Minnesota, New York, *North

Carolina and Pennsylvania.

+Bacterial spot caused by Bacterium woodsii EFS:

Oklahoma - Payne County, November 4. (Stratton)

Wilt caused by Fusarium incarnatum (Desm.) Saca.

+Florida - reported from various localities by florists; it caused

a wilting and final destruction of the plant; was of nuch

importance in isulated instances. (Weber)

Prior report: Indiana.

Root rot caused by Rhiz octonia sp.

Now York - Cortland Cjunty, June 3. Colleoted by R. S. Kirby.

(Chupp)

Prior reports: Conneoticut, Delaware, Idaho, Indiana, Maryland, Massachusetts, New Jersey, *New York, "North Carolina, Ohis,

*Penns y lvania and Vashinjton.

Rust caused by Uromyces caryophyllinus (Schrank) Wint.

Connecticut - one report, Danberry, Fairfield County, January 27. (clinton)

New York - Bronx County, May 12.

Niajara County - one zreenhouse with $95 \%$ infection

Erie County - one Ereenhouse with $30 \%$ infection

Bronx County - trace in Ereenhouse

Cortland County - trace in greenhouse

Bromie County - trace in greenhouse

Tompkins Cunty - epidemic in collese (Chupp)

+Florida - was collectod at Ginesville and Jacksonville the only

places reported in the state. (Heber)

Mississippi - one repurt; heavy infection in greenhouse, April

30, Washington County; this disease:probably occurred else-

where in greenhouses; it is frequently very serious. (Neal \& Barker)

Ohio - is of considerable impurtance; the malformation of leaves reduced the visor of the plant; fuund in greenhouses where ventilation is not very good; Cuyahoga, Erie, Franklin and Wayne Counties. (Detmers)

Indiana - common in freenhouses; inconspicuous in summer, bad in winter, Tippecan oe Cunty. (Gardner)

Illinois - light infection reported in small beds near Monmouth, Warren County, and 50\% in greenhouses near Galesburg, Knox County. (Tehon)

* Missouri - Boone, Buchanan, Butler, Jackson, Newton, and St.

Louis Counties. (Maneval)

Colorado - confined to greenhouse conditions; Ft. Collins, Larimer County, March. (Learn)

Pri or reports: ilabama, *California, Connecticut, Delaware, *District of Columbia, Idahu, *Iowa, *Kansas, Kentucky, *Vaine, Maryland, *Massachusetts, *Michigan, Minnes uta, *Mississippi, Nebraska, Nevada, New Jersey, *New York, North Car lina, *Ohio, Oklahoma, Oregon, *Pennsylvania, *South Carolina, South Dakota, *Texas, Utah, *Vermant, Washington and West Virginia.

White tip caused by fumigation injury

Connecticut - one report; Danbury, Fairfiuld County, January 27. (clint on) 
CHRISTMAS ROSE (Helleborus niger)

Loafspot caused by Cunijthyrium helleburi Cke. arà Mass. +New York - Monr Je Cunty, September 19. (Chupp).

Prior report: *Oregon.

Chrysanthemum (Chrysanthemum sp.)

Puwdery mildew caused by Erysiphe cichoracearum DC. (Oidium chrysanthemi)

+New York - frequent on young plants in jreenhouses; Genesee County, Ausust 22. (Chupp)

+New Jersey - severe, Mrs. Voight; medium, Baby, Flberon, Percy Dove; slight, Marigold, C.. Twigs, H. V. West; none, Wm. Turner, Yellow Tumer, Chieftain. (Hsenseler). Reported from Patters on, Passaic (jounty, Ontober 12. (Dept. Pl. Path.) Delaware - observed unly in greenhouses and less prevalent than in 1922. (hdams)

Prior reports: Delaware, Maryland, *Massarihusetts, Minnesota, Nebraska, North Carulina, Ohio, Pennsylvania, S suth Carolina, Utah, and West Virginia.

Wilt caused by Fusarium sp.

PFlorida - local distribution; of no econmic importance. (Weber)

A. labama - locally important, Mubile Cunty. (Miles)

+Kansas - of slight importance; reported only from grcenhouses at Independerce, Montg mery County. (mite)

Has been found also in Massachusetts, New Jersey and Ohij. Root gall csused by Heter dera radicicola (Greef.) Mueli.

+Washingtun - Spukine C Junty. (Heald: \& Dana)

Priur repurt: *Texas.

Leafspot caused by Phyllusticta chrysanthemi Ell. \& Desm.

-Florida - causod the defuliation of plants just before blossomin time; was widely scattered over the plants; severe, the host plants being killed; Gainesville, Alachua Cunty. (Webor)

Prior report: Massachusetts.

Leafspot caused by Septoria chrysanthemella Cav.

Prior report's: Connecticut, Delaware, Georgia, Maryland, Massachusetts, Minnesuta, Mississippi, Nebraska, New Jersey, North Car olina, Oklahoma, Pennsylvania, S Juth Carolina, Texas and "lest Virginia.

+Iilt caused by Verticillium albj-atrum Roinke \&.Berth.

New Jersey - causes a dwarfing with slow wilting and the dying of the leaves from the, base upward; it attacks the host at all stages of ; $r$ owth and cuused injury throughout the season; noted in 13 varieties in sreenhouses and outdoors durine the past six years; Pink Seidewich, Early Snow and P. A. Duve very susceptible; artificial inoculation with

V. albo-atrum successful. (Haenseler) Recent 'iteratire:

Chifflot, Jean. Maladies et parasitos des boutures de chrysanthemes. (Diseases and purasites of chrysanthemum cuttings). Cons res Path. Vez. Strasburg, 42-44. Imprimerie ilsacienne: Strasbure, 1923.

Goodey, T. A. A review of the plant parasitic members of the genus hphelenclis.. jur. Helminth 1 . 1: 143-156. Sopt. 1923. Citcs the following: Described in 1911; Aphelenchus ritzema-bosi Schwartz (1. phyllophagus 
Stewert, 1921); Findoparasitic in leaves of chrysanthemums calis ing destruction and disculuration of leaf tissue.

Sinderound, J. A note on the occurrence fo holenchus phyllophajus in chrysanthemums in the Transvarl, with suǵs,estions for its control:. So. African Jour. Sei. 19: 233-235. 1922 .

\section{CLEMATIS (Clematis $\mathrm{sp}$. )}

Root knot caused by Heterodera radicic Jla (-Greef.) Muell.

\section{+Oreg on - Orancu, Washington County. (Heald \& Dana)}

Prior reports: Alabama, Ohio and Washinston.

CRAPEMYRTLE (Lagerstroumia inaica).

+ Leafspot caused by Pestalozzia guepini Desm.

Florida - rosulted in the def Jliation of severely infected plants; in jeneral the discase was not serious although it was widespread. (Wober)

CROCUS, SHFFRON (Crjous sativus)

Bacterial rot causea by Bacterium croci Mizusawa

Recent litor ture:

Mizusawn, Y. A bacterial $r$ t disease of saffrons. Ann.

Phytupath. Soc. iapan 1: 1-12. 1923.

CYC LAMEIN (Cyclamen sp.)

+Black root $r$ t causce by Thielavir basicola (B. \& Br.) Zopf.

Connecticut - new host to Connecticut; one report from liew Haven, New Haven Cunty, February. (NoCormick)

CYDONIA, ITPONICA (Japanese Quince)

+Fire bli jht causcà by Bacillus amylov srus (Burr.) Trev.

lichigan - severe. (A. E. Gravatt)

DAHIIA (Dahlia sp.)

Powdery mildew caused by Erysiphe polyg,uni DC.

+Delaware - more senerally prevalent in New Castlo Cunty follow-

ing heavy rains in September. (idams)

+California - commun, Santa Ana, Oranse Cuunty, September 5.

(Harter \& Weimur)

Prior reports: Ge uria and Missouri, while Erysiphe sp. has been

reported fr m I uwa, Maryland and North Cirjlina.

Wilt causcd by Fusarium sp.

Non Jersey - New Brunswick, Midalesex Cunty, Novembër 24. (Dept.

PI. Patio.)

Pennsylvania - crused a head blight; Washington Cjunty. (Thurston) Leafr JII and mosaic - cause not determined

+Delaware - symptoms similar to leaf rolil and mosaic on potetoes;

becoming of increasing importance; many gardeners are des-

troying the rosts of affected plants thereby reducine the

distribution of the disease. (fidams)

Sclerotinia libertiana Fokl.

Recent literature:

Cuok, M. T. A disease of dahlias. Phytopath. 13: 285. June 1923. 


\section{DriISY}

Southern blight caused by Sclerotium rolfsii Sacc.

Mississippi - one report, Fashingtun County, June 30. (Neal \& Barker)

DAISY, MICHAEIMAS (Aster tradescanti)

Wilt caused by Cephalosporium aster is Dowson

Recent literature:

Dowson, W. J. Contributions from the Wisley Laboratory. The wilt disease of Michaelmas daisies. Tour. Roy Hort. Soc. $48: 38-57 \cdot 1923$.

DAISY, PARIS - See Marguerite

DÁISY, SHASTA (Chrysanthemum maximum hor. var.)

+ Leafspot caused by Septoria sp.

California - Santa.Ana, Orane County, September 5. (Harter \& Weimer)

DELPHINIUM (Delphinium sp.)

Bacterial spot caused by Bacterium delphinii (EFS.) Bryan

Connecticut - two repurts; Jne serious Hartford (Hartford, June

16) and New Haven Counties. (Clintion)

Prior reports: Connecticut, *Maine, *Massachusetts, *New York and Pennsylvania.

+ Sclerotial dis aso caused by Sclervtium delphinil D. S. Tolch

Recent litor ture:

Welch, D. S. h soler tial disease of cultivated delphinium. (ilbstract) Phyt op th. 14: 31. 1924. Cites that this disease has beon fund in New York, Pennsylvania, Indiana and Now Jersey.

Suthern wilt caused by Scler ttium rulfsii Sacc.

+Florida - caused the loss of host plants by firdling the stem at the soil surfsce, St. Augustine, St. Johns Cunty. (Weber)

Prior reports: *District of Culumbia, *Illinsis, *Indiana, *Luisiana ana $*$ New Jorsey.

Wilt or dr jp caused by Sclerotium sp.

New York - froquently pliants are killed; Genesce, Monroe (August

21) and Wy oming' C unties. (Chupp)

Prior repurts: Connecticut and *Maryland.

* + Volutelia sp.

District jf Columbia - Department of Agriculture gr junds. (.Tenkins) Black bli ht or mosaic - cause unknown

New York - Massey roports that $50 \%$ of the crop in a mixed commercial planting was injured; estimated loss was about $\$ 900$, June 10. (Chupp)

Rust - cause not determined

Ohio - one specimen of Delphinium reported ts be affected with rust showed a dyine of leaves, but no definite pathogenic orcanism could be detected, Rscky River, Cuyahog,a County, Aur,ust 15. (Young)

DE LPHINIUM, HARDY (Deiphinium formosum)

+ powdery mildew caused by Frysiphe pulyzjni DC.

New York - found in University Perennial Gardens; Ithaca, Tompkins Cunty, Soptember 8. (Chupp) 


\section{DFUTizIA (Deutzia sp.)}

+Root knot caused by Heterodera radicicjla (Greef.) Muell. +Mississippi - one report; severe local infection in nursery; C.ovinston County, Nay 11. (NeaI \& Barker).

\section{EUONYMUS (Fuonymus sp.)}

Leafspot causcd by Exosporium concentricum Heald \& VIJ If

Texas - provalent; reported from six cunties in eastern half of state. (Taubenhaus)

t Anthracnuse caused by Gloe ssporium frigidum Sacc.

Mississipi - jeneral throughout state; causes a rather serious sputtinis of loaves; Covin jon County, May 15. (Neal \& Barker)

Powdery mildew caused by Microsphaer ieuonymi (DC.) Sacc.

+Mississiopi - sne report; li:ht infection; Coahoma County. (Neal \& Barkur). Prior report: New Jersey.

* Mildew causeả by Oidium eu onymi-japonica (Arc.) Srcc.

IJuisiana - apparently only jocurs in the Shreveport section of the stutu; Bolcher, Caddo County; May 25. (Edserton)

Root rot caused by Ozonium omnivorum Shear:

Texás - prevalent; caused about 5\% Ioss. (Taubenhaus)

FALST, DRígONHELD - Soe Physustecia

FERN, CHRISTMLS (PJlystichum acrustichoides)

Taphrin filioin Rustr. (Pxuscus filicinus (Rostr.) Sacc.

*Virk, inis - noer Chain Bridse, Fairfax. Cunty, hay 19. Collected by A. Jorkins. (Jenkins).

Prior roports: *District of Columbia, *Maryland and *North carolina.

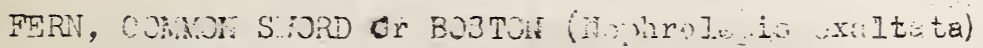

+Anthracruse caused by Glumerella nemhrlepis Faris

Recent literäture:

Faris, J. H. Anthracnose of the. Boston fern...Myculogia 15: 89-95. Mar. 1923. Tentatively called Glomerella nephr lepis. The article cites that this disease was first jbserved at the Brooklyn Botanic Garden, New York, in 1919 .

FLONERIIG QUTINCE. - See Cydunia japonica.

FORSYTHI, FORTUNE (Forsythia suspensa var. fortunei)

+Winter injury

New York - E. E. Hun oy roported that a row jo plants on the suth side of a house al on Itheca, Tumpikins Cunty. (Chupp)

FORSYTHIA (Forsythia s..)

+Crown iaIl caused by Bacterium tumefaciens EFS. \& TJwn.

Mississippi: - one report; slijht; Covintton Cunty, May 11. (Neal \& Barker)

+Rjot knut caused by Heterodera radicicjla (Greef.) Mell.

Miss issippi - one report; heavy infection in nursery; Covington Cunty, May 11. (Neal \& Barker) 
FUNKIA (Hosta sp.)

+Leafspot caused by Altemaria sp.

New York - jeneril; Dutchess County, August 23. (Cbupp).

Prior report: Michizan.

GFRAIIUM (Peläreoniurn sp.)

Bacterial leafspot caused by Bacterium erodii I. M. Lewis

+Mississipi - wides rread over the state; caused serious damaje. (Neal \& Barker)

Indiana - one report; Flkhart, Flkhart.County, July 21. (Gardner)

Prior reports: Indiana, *New Jersey, Ohio, *Pennsylvania and

Washinston.

Bacterial lonfspot caused by Bacterium pelargoni N. Brown

Recent litersture:

Brown, N. $\dot{A}$. Bacterial lea fspot of Geranium in the eastern United States. Reprint from Jour. Agr. Res. 23: 361-772. 1923. Occurs in various parts of eastern United States from Vir inia to Massachusetts. Especially prevalent and destructive in New Jersey and. Maryland; mostly in the Ereenhouse; not the same as Bacterium erodii Lewis, described from Texas in 1914.

Wilt caused by Bacterium sp.

+Florida - common but not severe; caused the death of geraniums near Tampa and Plant City, Hillsborough County. (Weber) Blackle of cuttinis ciused by Pythium debaryanum Hesse

Recent literature:

Buddin, W. and E. M. Wakefield. Blackleg. of.Pelar Eonium cuttings. Gard. Chron. 75: 25. Jan. 12, 1924.

GLíDIOLUS (Gladiolus sp.)

+Bacterial blizht caused by Bacterium zummisudans McC.

Michisan - Ovid, Clint on County. (McCulloch)

Recent literature:

McCulloch, L. A bacterial blight of Eladioli. Jour. Agr. Res.

27: 225-230. Jan: 1924.

Bacterial rot caused by Bacterium marinatu $\mathrm{McC}$.

Recent literature:

McCulloch, Lucia. Two bacterial diseases of sladiolus. (Abstract) Phytopath. 14: 63: Jan. 1924.

Fusarium spp.

New York - a rot of corms; affected $2 \%$ of the plants in a small plantin. (Massey)

+New Jersey - caused a wilt; Nuw Brunswick, Middlesex County, Septomber 29. (Dept. Pl. Path.)

Ohio - forms a scab on the corm which impairs visor; seems to develop in storaije; of muderate importance; Cuyahosa and Lickin̈ (February 10) Counties. (Detmers)

Hard rot caused by Septoria jladioli Pass.

New York - produced a death of plints in July and Ausust resultin: from the premature decay of parent corm; leafspots on foliage of seedline and cormels; Rensaelaer County, Ausust 1. (Massey)

*Michisan - Clinton, In tham and Macomb Counties. (Coons)

Prior report: Indiana and Minnesota.

Bacterial leafspot - cause undetermineu

Michiéan - probably widespread; Ovid, Clinton County. (Coons) 
Minnesota - in onelfiold; infestion heaviest on variety Maiden

Blush, Rumsey County; also Hennepin and Rock Counties. (Sect. PI. Path.)

GOLDEN GIOW (Ruảbeckia laciniata Hort. var.)

Powdery mildew caused by Erysiphe cichoracearum DC.

Comnecticut - not bad, New Haven, New Haven County, July 30.

(clirton)

* New York - probably statewide; Suffolk County, Ausust 10. (Chipu).

Prior reports: *Conneeticut, Indiana, *Maryland, *ohio and West Viroinia.

HEDGRHOG (Coneflower) (Tchinacea purpurea)

+Mosaic - cause undetermined.

New York - Dutchess County, June 17. Collected ky Kirby and Honey. (Chupp)

HELLEBORE - See Christmas Rose

HIBISCUS (Hibiscus sp.) .

Bacterial blicht causad by Bacterium hibisci Nakada \& Takimoto Recent liter ture:

Nakada, N. and K. Takimoto. Bacterial blight of Hibiscus. inn. Phytopath. Soc. Japan 1: 13-19. 1923.

+Crow jall caused by Bacterium tumefaciens EFS... \& Town.

Mississippi - sliêtht infection; Ieflore County, May I. (Neal \& Barker)

+hnthracnose caused by Colletotrichum hibisci Poll.

Florida - collected at two places in the state but resulted in no serious damase. (Weber)

+Wilt caused by Fusarium berkeleyi Mont.

Florida - cause of the loss of a number of plants; appeared to be a soil infection; Howey, Lake County. (Weber)

+Root knot caused by Heterodera radicicola (Greef.). Muell.

Texas - trace, Brazos county. (Taubenhaus).

Leafspot caused by Phyllosticta hibiscina Ell. \& Ev. (P. hibisci Pk.)

* Hew York - Nassau County, huEust 10. (Chupp)

Prior report: *Connectincit.

Bacterial wilt - cause undetermined

Florida - found to be the cause of considerable.wilting of the hos.t plant. (Iober).

HOLLEY, AMERICiN (Ilex opaca)

Leafspot caused by Phyllosticta ilicicola (Cke. \& Ell.) Ell. \& Ev. +New York - common; 10 to $20 \%$ of leaves infected. (Chupp)

Prior report: New Jersey.

HOLLYHOCK (AIthaea rosea)

+ Ieafspot caused by Ascochyta althaeina Sacc. \& Bizz.

New York - Nassau County, hujust 10. Collected by W. D. Mills. (Chupp)

Leafispot caused by Cercospora althaeina Sacc.

Delaware - irfection later than usually observed; spread very rapidly durine September; Kent and Newcastle (Hollyoak) Counties, September. (hdams) 
+Mississippi - ippeared tu be rather serious; Monroe County, June 17. (Neal \& Barker)

+Oklahoma - Payne County, November 5. (Stratton)

Prior reports: Alabama, Connecticut, *Delaware, Indiana, *Kansas, Massachusetts, *Michican, Minnesota, *Nebraska, *Pennsylvania, *Texas, and West Virginia.

Anthracnose caused by Colletotrichum ma lvarum Br. \& Casp.

+New York - Forestville, Chautauqua County, June 30. (Chupp)

Prior report: Ohio.

Root rot caused by Ozonium omnivorum Shear.

Texas - hinders the ornamental value; about $10 \%$ reduction; Bell

County. (Taubenhaus)

Rust caused by Puccinia malvacearum Bertero

Prior reports: Connecticut, *New York, New Jersey, +Solith CaroIina, +Mississippi, Ohio, Colorado, Washington and *California.

HONEYSUCKIE, TATARIAN (Lonicera tatarica)

Powdery mildew caused by Microsphaeria alni (Wallr.) Wint.

+New York - Oswec̃o County, August 30. (Chupp)

Prior reports: Iowa, Ninnesota, New York, and Penusylrania.

HONEYSUCKLE (Lonicera sp.)

Powdery mildew caused by Microsphaeria alni (Wallr.) wint.

+New York - Oswego County, Ausust 30 . (Chupp)

Prior reports: *Connecticut, *Iowa, *Massachusetts, *Michigan,

Minnesota, *Nebraska, New York and Washington.

+Necrosis - cause unknown

Wisconsin - quick drying of top in hot weather, seems to be worse where plant is in semi-shade ( 5 to 4 hours sunlight); no indication of fun ${ }^{i} i$ present, Madison, Dane County, July 15. (Vaughan)

HYACINTH (Hyacinthus orientalis)

+Dry bilb rot caused by Fusarium sp.

Missouri - damą; severe; Carterville, Jasper County. (Maneval) +Nema disease caused by Tylenchus dipsaci (Kuhn) Bast.

Washiniton - Sprikane County. (Heald \& Dana)

HYDRAIJEh (Hydranïea sp.)

+ Root knot caused by Heterodera radicicola (Greef.) Muell.

Mississippi - sli ht infection Tunica County, April 28. (Neal \& Barker)

Powdery mildew ciused by Oidium sp.

Florida - h:s been destructive on the host plint, especially when it was jrow under more or less moist, shady conditions. (Weber)

Leafspot caused by Phyllosticta hydranieae Ell. \& Ev.

+Alabama - severe in a nursery in Mobile, Mobile County; the decorative value of the plants was larely destroyed whioh consequently affected the sale value; locally important; produced. large brown blotohes on the leaves. (Miles)

Prior report: Now Jursey. 
Florida - cullected durin; May and June on this host plant which was severely attackin; the leaflets and defoliuting the whole plant; both uredinia and tulia stages were present. (weber)

IRIS (Iris sp.)

Soft rot caused by Bacillus carotovorus $L$. R. Jones

New York - Tompkins County, May 21. (Chupp)

+Indiana - worst disease with which iris growers had to contelid.

Tippecanoe and Welis Countiès. (Jackson)

Prior reports: Connecticut, Michisan, Minnesota and Ohio.

Recent literatur:

Richrison, J. K. Bacterial soft rot of iris. (Abstract) Phytopath. 13: 293. 1923.

A study of soft rot of iris. Ann. Rept. Quebce Soc. Prot. Plants. 15: 105-121. 1922-1923.

Leafspot caused by nidymellina iriais (Desm.) von H. (Heterosnorium

irasile: (Wallr. Saco.)

Connecticut - New Haven (June 18) and Tow land Counties. (Clinton)

New York - important locally; Kirby and Honey reported as follows:

Variety Spectabilis $100 \%$ infection; varieties, Honorabilis

and Madam Cherau sIisht infection; also reported on Iris

versiculor; reported from six counties; Dutchess County,

June 17. (Chupp)

+Pennsy Ivania - Center County. (Thurston).

+Indiana - worse than average year; common about Lafayette,

Tippecanoe County, May 25; period of greatest injury about

Ausust 1. (Jackson \& Gardiner).

-Missouri - damaje not great; no doubt general over state; common

at Columbia, BooneCounty. (Maneval):

Prior reports: *Connecticut, *Bistrict of Columbia, *Kansas,

*Maine, *Maryland, *Michigan, Minnesota, *New York and * Iexas.

+Wilt caused by Sclerotinia sclerotiorum (Lib.) Mass.

Washington - Kinf County. (HeaId \& Dana)

Southern blight caused by Sclerotium rolfsii:Sacc.

+Mississippi - rather severe. local rottins of leaf blades and

bulbs; Oktibbeha County, Tune 25. (Neal \& Barker)

+Indiana - noted in numerous tardens about Lafayette, Tippecanoe

County; reported from Bluffton, WeIl County. (Jackson \&

Gardner). Prior report: *Maryland.

IVY, ENGLISH (Hedera helix)

Leafspot caused by Phyllosticta concentrica Sacc.

+South Carolina - unimportant; Greenville County, May 11. (Ludwig)

Prior report: Alabama, *New Jersey and *Texas.

Leafspot caused by Phyllosticta heleraecola Dur. \& Mont.

*+New York - Nassau County, Au fust 6. (Chrpp)

Prior report: New Jersey.

IVY, JAPANESE - See Ampelopsis tricuspidata

KALMIA (Kalnia latifolia)

+ Leafspot caused by Venturia kalmiae Pk.

New York - Oränge County, June 17. (Chupp) 
* Leafspot caused oy Septoria sp.

Virinia - Mt. Vernon, Fuirfax County, June 11. Colleoted hy R. J. Haskeli.

LARKSPUR - See Delphinium sp.

LAUREL, CHFRRY (Laurocerasus sp.)

+ Leafsnot caused by Phyllosticta Iaurocerasi Sacc. \& Speg.

Florida - found near Gainesville, flachua County, and reported

from Pensacola, Escambia Cuunty, as doing considerable dan-

aige to hedises of the host plant causing defoliation. (Weber)

LAUREL, MOUNTAIN - See Kalmia

IILAC, CONMON (Syringá vulsaris)

+Hymenochaete agilutinans Eli.

Connectiout - had zirdled to the stem where present; not a serious

truble; new to state on this host; Mangfiezd, Tolzand

County, May 6. (clinton)

Powdery mildew caused by Microsphaera alni (Wallr.) Wint.

Reported from *New York, New Tersey, Delaware, Iowa and California. + Silver leaf caused by Stereum purpureum Fr.

Oklahoma - Payne county, October 5. (Stratton)

LILY, CANADA. (IIIIUm canadense)

Rust caused by Uromyoes holwayi Lagh.

* +New York - Ellis Hollow, May 27. Collected by H. H. Whetzel.

Prior report: *Maine.

LILY, EHSTER (Lilium long iflorum)

tGray mold caused by Botrjtis, cinerea type

Florida - serious disease of the flowering parts during the past season; also reported on leaves. (Wëber).

+ Leafspot caused by Cercospora unicolor S. \& P.

Floride - f jund to be widely scattered and prevalent over the state; very little damage resulted. (Weber)

+Wilt caused by Fusirium sp.

Flurida - ruined several large beds of lilies during the past season; not reported elsewhere in the state. (Weber)

+Wilt caused by Sclerotinia sclerotiorum ( Lib.) Mass.

Florida - reported as occuring in a flower bed; causing some damage; Jacksonville, Duval County. (Weber)

+Mosaic - cause unknown

Florida - reported widespread over the state; caused loss of lants; ilachua (Gainesville), Hillsborough (Tampa) and St. Lucia (Sebastian) Counties.. (Weber)

IOBELTA, LARGE BLUE (Lobelia siphilitica)

Rust caused by Puccinia lobeliae Ger.

*+New York - Tompkins County, October 5. (Chupp)

Prior reports: *Arkansas, *Delaware, *Illinois, *Indiana, * owa,

* Kansas, *Missouri, *Nebraska and *Wisconsin

Leafspot caused by Septoria lobeliae Pk.

+New York - Oswegुo (September 10) and Onondaga Counties. (Chupp)

Prior report: *Illinois, *Iowa, *Nebraska and *Wisconsin. 
LONICERA - See Honeysuckle

LUPINE (Lupinus sp.)

Botrytis cinerea Pers. and iscochyta pisi Lib.

Recent Iiterature:

Curtis, K. M. Two fun al diseases of the blue Iupine. New Zealand Jour. of ACr. 14: 240-246. 1923.

MARGUERITE (Chrysanthemum frutescens)

Crown gal1 caused by Bacterium tumefaciens EFS. \& Town.

Recent literature:

Dowson, W. J. Contributions from the Wisley Laboratory.

The wilt diseases of Michaelmas daisies. Jour. Roy.

Hort. Soc. 48: 38-57. 1923.

MATRIMONY VINE, COMMON (Lycium halimifolium)

+Powdery mildew caused by Cicinnobolus caesatil DEy.

Ohio - of slicht importance; Wayne County, September. (Detmers)

+Powdery mildew caused by Erysiphe pJlyzoni DC.

Delaware - usual prevalence observed in New Castle County and

associated with leaves showing mite infection. (Adams)

Rust caused by puccinia lycii Kalch.

Ohio - attacked leaves, Wayne Cunty, October. (Detmers)

Prior reports: *Kansas, Massachusetts, * *iebraska, Ohio and *Virsinia.

MIGNONETTE, COMMON (Reseda odorata).

Leafspot caused by Cercospora resedae Fckl.

+Missouri - collected in a Greenhouse;: Columbia, Boone County.

(Maneval). Prior reports: Connecticut, *District of Columbia,

*Illinois, Indiana, *Massachusetts, *Mississippi, Missouri

anà *Pennsylvania.

MORNING GIORY (Ipomoea purpurẹa)

White rust caused by Albuso ipomocae-panduranae (Schw.) Sw.

Mississippi - ceneral and heavy; Oktibbeha County, Ausust 30.

(Neal \& Barker)

Prior reports: *Alabama, *Delaware, *Gejrgia, Kansas, *Mississippi,

*Virsinia and West Viruinia.

Rust caused by Cole ssporium ipomoeae (Schw.) Burr:.

+Mississippi - Seneral and heavy; Oktibbeha County, September 15.

(Neal \& Barker)

Prior reports.: *Alabama, *Arkansas, *Illinois, *Louisiana, *Mississippi,

*Miss juri, and *Texas.

+Rust caysed by Puccinia ipomocae-panduratae (Schw.) Syd. (

+oklahoma - Payne County, October 15. (Stratton)

+Stem canker caused by Vermicularia ipomearum. Schw.

New York - Kirby and Honey report new dis ease for the state; not

in the herbarium nor given in North American Flora. (Cnupp)

\section{MOUNTAIN LAUREL - See KaImia}

NASTURTIUM, COMMON (Tropaeolum majus)

Leafspot caused by Bacterium aptatum Brown \& Jamieson

+Mississippi - LinouIn County, May 28. (Neal \& Barker)

Prior report: New Jersey. 
Wilt caused by Baoterium sulanacearum EFS.

+Flurida - very severe un nasturtiums during the past seas on, killins practically all plantin;s in the vioinity of Gainesville; the first symptums became evident when the plants befian to blussum; 100\% of the plants wore affected and must of them died. (Tubert

Prior reports: Maryland and Virsinia.

+Leafspot caused by Pleospora herbarum (Pers.) Rabh.

Ohio - one report; causes spotting and death of leaves; MoComells ville, Morgan County, June 27. (Young)

OIEANDER (Nerium oleander)

Leafspot caused by Phyllosticta sp.

Florida - large brown spots on the leaves caused sume defuliation. (Wober)

Speckel leafspot caused by Septoria sp.

Florida - caused: some defoliation but not of a serious. nature. (Wober)

\section{ORCHID}

Leafspot caused by Diplodia sp.

Florida - causad consiaerable lóss of foliage; Palm Beach, Palm Beach Cunty. (iveber)

OXALIS (Oxalis sp.)

Rust caused by Uredo oxalidis Lev.

+ Florida - caused $100 \%$ infection, killing all the foliage in two to three weeks; Alachua (Gainesville and Micanopy, February), Manatee (Onees, May) Counties. (Weber).

Prior report: Texas.

PAIM

Anthracnose caused by Collet otrichum sp.

South Carolina - Beaufort County. (Ludwig)

Leafspot caused by Gloeosporium sp.

New York - Albany, Albany County, September 2. (Chupp)

False smut caused by GraphiJla phoenicis (Moug.) Poft.

Louisiana - Reserve, St. John Cuunty, September. (Edgertun)

PALM, COCOAINUT (Cocos nucifera)

Wilt - cause unkn own

Flurida - leaves boc ume yellow and wilt one after another until the bud falls from the top of the plant. A Pythium sp. has been ubtained most consistently in is olation eultures. (Weber, 2. F. Field work in Florida during the year on disease cuntrul. Quar. Bui. Fla. State Pl. Ba. 8: 3-4. Oct. 1923.

PALM, CANARY DATE (Phoenix canariensis)

Leafspot caused by Exosporium palmivorum Sacc.

*Luis iana - East Baton Rouge C sunty. (Edgerton)

False smut oaused by Graphisla phoenicis (Moug.) Poit.

**FIorida - New Aueustine, St. Johns County, November. (Kniskern)

Prior reports: *California,.. ${ }^{*}$ District of Columbia, Louisiana, *Mississippi, *New York and *Pennsylvania. 
PALM, DAIE (Phoenix sp.)

Leafspot caused by Exosporium valmivorum Sacc.

+Florida - caused very serious losses to these plants; reported from the whole state in general; especially sever in nurseries and along the East Coast; in many instances total defoliation and destruetion of the plant was reported; it was widespread but rot destruative as a whole. (Veber)

Prior report: *Mississippi.

+ Leafspot caused by Ramularia sp.

Florida - nut of economic importance; Gainesville, Alachua County, Septembar. ( Teber)

PAIM, MEYICAN WASTMYNON (Jashingtonia robusta)

Wilt - causc unknown

Flonids - the wilt associated with Pythium mentioned on the preceding jage under cocoanut palm has been noted on this host. (See palm, cocoanut)

PALM, WASHIIGTON ("ashingtonia $\mathrm{sp}$. )

+ Leafspot caised by Pstalozzia palmicola S. \& B.

Florida - destructive to the leaves, Gainesville, beginning at the tips of the lcaves and gradually working toward the petiale, killing the tissue and turning it brown; serious on plunts used for ornamental purposes. (Weber)

PALMETTO (Sabal sp.)

False smut caus by Graphiola phoenicis (Moug.) Poit. + Florida - common. (itober)

Leafspot caused by Pestalozzia palmicola S. \&.S.

+Florida - comon; ofton causing partial defoliation. (Weber)

Bacterial' leafspot - cause undetermined

Florida - caused duath of leaves on several plants; not common; collected at Tampa. (Nober)

PAISY (Viola triojlor)

Leafspot caused by ilternaria violae Gall. \&. Dorsett

Hew York - Norro County, Soptember 9. Collected by E. F. Guba.

(Chupp). Prior roport: *Ponnsylvania.

Leafspot causud by golletotrichum violac-tricoloris Sm.

+New York - Monro County. Collected by E. F. Guba. (Chupp)

Prior repóts: Massachusetts and New Jersey.

+ Root rot caus d y thium debaryanum Hesse

Conneticit - N w Wuvr, IJow Haven County, July 11. (MoCormick)

+Lofspot caus d by Ramularia sp.

Washington - Grays Harbor Curity. (Heald \& Dana)

+Black root rot caused by miclavia basicola (Bork. a Br.) Zopf.

Connectiout - Westrille, New Haven County, June 28. (MoCormick)

PEOIVY (Paeonia spp.)

Luafipot cuused by Alternaria sp.

* Kansas - undor observation; out of forty-four varieties exained eight siowed marked resistance and were practically frue from the discase; nature plants only seem to be susceptible; the spot doos not show up until after blossoming and apparentiy causus little damage to the vitality of the root stook; 
Topeka, Shawnee County. Collected by $\pi$. P. White. (White) Prior report: Nebraska.

Blight oaused by Botrytis paeoniae Oud.

+Alabama - locally important; in a gruenhouse at Mobile and a lawn planting in Tuscaloosa County; plants badly affected; some killed. (Miles)

Ohio - one report; Champaign County; September 7: (Detmers)

+New York - very injurious; statewide; Thetzel reports one very early variety always severely affected; also collected by Whetzel on Paeonia grandiflora and $\underline{p}$. officinalis rubra, Tompkins County, May 6. (Chupp)

Tompkins County -- 10\% of new shoots of 100 plants killed. Monroe County -- $50 \%$ of 50 plants, $5 \%$ of new shoots killed. Nassau County -- 10\% of shoots infeoted.

Genesee County -- common on blossom buds, 2 to $5 \%$ injured. On May 6, the shoot rot stage just began; all infection

starts below the surface of the soil. (thetzel)

Prior reports: Delaware, Idaho, *Maryland, *Massachusetts, Michigan, Minnesota, New Hampshire, *New York, Ohio, *Pennsylvania,

*Rhode Island; Utah and *Virginia

Gray mold rot caused by Botrytis sp.

+Conrecticut - two reports; possibly follows Pythium injury;

Hamden, New Haven County, May 21. (Clinton)

Pennsylvania - Center and Perry Counties. (Thurston)

Leaf mold caused by Cladosporium paeoniae Pass.

+ Aabama - unimportant; found in a nursery in Mobile County. (Miles)

* Kansas - general in range; great range in susceptibility; over

50 varieties examined in several nurseries, Folix Gussee Variety most susceptible of all; destroyed leaf area reaches from 0 to 90\%; attacks host immodiatoly after blooming; first report but has been present for years; Topek 7 , Shawnee County, June 13. (Thite)

Prior reports: Alabama, *Alaska, Connecticut, *Distriot of Columbia, Indiana, *Iowa, *Mary la nd, Michigan, Minnesota, *Mississippi, *Miss ouri, New Jersey,*Ohio and Washington.

Dry bulb rot caused by Fusarium sp.

+Missouri - Carterville, Jasper County. (Maneval)

Prior reports: *Indiana and *Nebraska.

Root knot caused by Heterodera radicioola (Greef.) Muell.

+New York - Mt. Vernon, Westchester County, October 21. (Strayer)

+Mississippi - very serious in a nursery, April 26. (Neal \& Barker)

Prior reports: Nebraska, Ohio and Pennsylvania.

Stem rot caused by Phytophthora sp.

+Conriecticut - attarked the stems both above and below the ground; apparently infected as they came through the ground; both Botrytis and Phytophthora present but tho latter is apparently the first invader and cause; Hamden, New Haven County.

(clinton). Prior reports: Karsas and Pennsylvania.

+Wilt caused by Verticillium albo-atrum Reinke \&: Berth.

Kansas - found only in one nursery, about $1 \%$ of the plants affected; no varietal resistance noted, July 10. (Thite) Leafspot - yellows - mosaic - cause undetermined

+Kansas - slight importance; same entire plants show this and other plants only one and two stalks;. Leavenworth, (Leavenworth, July 10) Shawnoe and Wyandotto Counties. (Thite) 
Prior reports: *Massachusetts and *Virginia.

Recent literature:

Auten, Edward, Jr. X-ray treatmont for peony root gall. Flower Grow. 10: 308. Sept. 1923.

Jan. 1924.

Spraying peonies peys. Flow. Grow: 11:23.

Coulson, J. G. Peony diseases. (Abstrant) Phytopath. 13: 292293. 1923.

Peony diseases: Ann. Rep. Quebec Soc. Prot. Plints. 15: 67-70. 1922-23.

PETUNIA (Petunia sp.)

Mosaic - cause unknown

+Connecticut - rather bad in potted plants in a greenhouse, July 6. (clinton)

+Luisiana - of little importance; noticed at Baton Rouge, East Baton Rouge County, January; first record of disease in state. (Edgerton). Prior reports: Iowa and Perins ylvania.

PHLOX (PhIox sp.)

+Crown gall caused by Bacterium tumefaciens EFS. \& Town. New Jersey - Richfield, September 29: (Dept. PI. Path.)

Anthracnse caused by Colletotrichum sp.

+Florida - local and not serious; caused canker-like lesions on the stems: (Weber). Prior report: *District. of Columbia. Powdery mildew caused by Erysiphe cichoracearum DC.

Reported from New Hampshire, Connecticut, $N$ w York and *Ohio.

Prior repjrts: Alabama, *Florida, *Indiana, *Ijuisiana, *Maine, *Maryland, *Massachusetts, Michigan, *Minnesota, *New Jersey,

*New.York, *Vermont, *Virginia," *Vashington, West Virginia and *Wisconsin.

Leafspot caused by Septoria sp.

New York - reported on $\mathrm{phlox}$ maculata and $\underline{\mathrm{P}}$. drummondi; Tompkins

County, june 10; this is an undescribed species of Septoria. (Chupp)

Powdery mildew caused by Sphacrotheca humuli (DC.) Búrr. +Kansas - Decatur County. (Ihite) Prior report: Ohio.

PHYSOSTEGIi (Physostegia sp.)

Root rot caused by Fusa rium sp.

+Kansas - Kansas City, Wyandotte County, September I2: : White)

PITTOSPORUM (Pittosporum sp.)

+Stem rot caused by Sclerotium rolfsii sacc:

Florida - not cummon or widely spread; coused considerable damage to the host pilant; Jaoksonvilie; Duyall County. (Weber)

POINC IANA, ROYAL (Poinciana regia).

+Anthracnose caused by Gloeosporium sp.

Florida - reported from Bradention, as causing slight damage; not common, Manatee County. (Webur)

POINSETTIA (Puinsettia pulcherrima)

+ Twig blight caused by Bacterium sp. 
Forida - caused considerable apprehensi nn during the past season by causing twigs and new vigor serious. (Weber)

+Wilt caused by Fusarium sp.

Florida - quite common in the vicinity of Gainesville, Alachua County; usually killed the plant; the leaves turned yellow and fell; the newest leaves were shed last and the plants usually dried. (iveber)

POPPY (Papaver sp.)

+ Leafspot caused by Cercospore11a sp.

Florida - killed the leaves at blossoming time; Gainesville, Alachua County. (Weber)

PRIVET ( Ligustrum sp.)

+Root rot caused by Armillaria mellea (Vahl) Quel.

Mississippi - appears to be general and frequently, causes considerable damage to hedges; Washington County, August 14. (Neal \& Barker)

+Crown gall caused by Bacterium tumefaciens EFS. \& Town.

Mississippi - apparently widespread, although had not been previously listed as susceptible; Ligustrum hicidum seemed particularly susceptible; also found on California, Nepals and Amoor River privets. (Barker \&: Neal)

+Root knot caused by Heterodera radicic)la (Greef.) Muell.

Mississippi - California variety affected; other varieties in same nursery not affected, May 11. (Neal \& Barker)

Root rot caused by Ozonium omnivorum Shear

Texas - prevalent; caused 1\% reduction in yield. (Taubenhaus)

QUINCE, FIONERING or JAPANESE - See Cydunia japonica

RASPBFRRY, FLONERING - See Rubus odoratus

RHODODENDRON, COAST' (Rhododendron californicum)

+Leafspot caused by Coryreum rhododendri Schw.

Oreg on - not abundant; Rujada, Lane County, June 17. (Boyce)

Rust caused by Melampsoropsis piperiana irtli.

Oreg on - rere; Waldport, Lincoln County, October 10. (Boyce)

+Bud blight caused by Sporocybe azaleae (Pk.) Sacc.

Orezon - rare; Rujadu, Lane County, Juno 17. (Boyce)

RHODODENDRON (Rhododendr on sp.)

+ Leafspot causid by Discosia sp.

New York - on Rhododendron miximum; Dutchess County, August 31. ( Chupp)

+ Leafspot caused by Monochaetia sp.

New York - Nassau County, June 1. (Chupp)

+ Itafspot caused by Mycosphaerella rhododendron Cke.

New York - on Rhododendron purpureum and $\underline{R}$. maximum; Nassau County, June 1. (Chupp)

Leafspot caused by Pestalozzia guepini Desm.

+New Yurk - Kirbv and Honey fuund it at Ruchoster on the following speoies: Rhodendron arborescens, $\underline{R}$. curoliniunum, and $\underline{R}$. cutawbierse; also found in Putnam County, June 16. (Chupp) 
+New Jersey - controlled by spraying wi.th bordeaux mixture and removing leaves; Bridgeton, Cumberland County. (Dept. PI. Path.)

Prior reports: Connecticut, Ielaware and *Indiana.

+Leafspot caused by Phyllosticta saccaraoi Thuem. cArolinionum

New York - found on Rhododendron maximumand R. earslianum. (Chupp)

ROSE, CHRISTMLS - See Hellebore.

ROSEMALLOW - See Hibiscus

ROSE (Rosa gentiliana)

* +Olpitrichum macrosporum (Farlow) Sumstine, probably saprophytic of the genus olpitrichum

Maryland - Bell Station, June 28; collected by Anna E. Jenkins; of interest as it has added new information to the knowledge. (Je..kins)

ROSE (Rose hug oris)

+Sphaeronemella rosae Ell. \& Ev.

* Maryland - experiment rose garden; on leaves and hips; Bell

Station, October 25. Collected by Anna E. Jenkins. (Jenkins)

*Virginia - Rossyln Notiryl Rose Test Garden, Arlington Experiment Station; collected by inna E. Jenkins; on leaves and hips; the furgus is isolated and grows in pure culture. Specimens from which the furgus is described were collected at Newfield, New Jersey, June 1889 and-issued as number 2566 Ell. \& Ev. North American Flora; this is the only other specimen of this fungus in the Pathologionl Collections. (Jenkins)

ROSE (Rosa spp.)

Crown gall caused by Bacterium tumefaciens EFS. \& Town.

Connecticut - Cromwe11, Middlesex County, August 29. (Clinton)

INew Jersey - heary infection noted in a greenhouse; causes galls 1 to $1-1 / 2$ irches in diameter on crown and roots. (Dept. Pl. Path.)

+Mississippi - general; rather serious in many nurseries, April 27. (Neal \& Barker)

+Louisiana - local; Bator Rouge, East Baton Rouge, January. (Edgerton)

+North Dakota - found on Rosa rubiginosa; important locally; has been shipped into state with nursery stock; Bismarck, Burleigh County, April. ("Neniger)

Prior reports: *District of Columbia, Illinois, Indiana, Maryland, * Viassachusetts, Michigan, Mirnesota, liew Hampshire, New

Mexico, New York, Ohio, *Pernsylvania and Washington. Botryosphaeria ribis Gross \& Dug.

*Marylard - Bell Station, March, June and October. Collected by

Anna E. Jenkins. (Jenkins). 'Prior report: Virginia.

Bud blast and canker caused by Botrytis cirerea Pers.

New York - following winter injury canker on cultivated seti-

lings and bud blast on wild rose, Seneca County, May 14. (Chupp)

+South Carolina - important locally; complicated with thrips injury and probably following it; the combination effectively prevented the production of good flowers in some places, Horry 
Botrytis sp.

(Nichols, May 16), Pickens and Richland Counties; period of greatest injury May 15 to 30 ; weather relations during the seas on moist. (Iudwig)

*Maryland - on Rosa sp. variety "Radiance" and also on other varieties; at the Darrow Tract, Bell Station; collected by Anna F. Jenkins, April 21. The fungus was isolated from discolored diseased areas on stems of plants kept over winter in outdoor heeling bed. (Jenkins)

+Mississippi - usually formed cankers at the base of twig, Sunflower County, spril 6. (Neal \& Barker)

Texas - produced a rot; local. (Taubenhaus)

Prior reports: Delaware, Indiana, Maryland, Massachusetts, Michigan, Montana, New York, Ohio,. Texas and Washington.

Leafspot caused by Cercospora rosicola Puss.

+South Carolina - Calhoun, Pickens County, September 11. (Ludwig)

+ Florida - Elmost universally present where roses were grown; it ranked next to powdery mildew in importance. (Weber)

Mississippi - McLean, Groen County, August 15. (Barker)

P.ior reports: *ilabama, Connecticut, *District of Columbia, *Florida, *Georgia, Indiana, *Iowa, *Louisiana, Michigan, Minnesota, *Mississippi, *Missouri, *Nebraska, New Jersey, *New York,: *South Carolina,. *Texa's, Wäshington, West Virginiz and Wisconsin.

Coniothyrium sp.

*New York - Cold Spring, Putnam County, Jure 2. (Jenkins)

* Maryland - Experimental Rose Garden, Bell Station, June 28. Collected by hinna E. Jenkins. (Jenkins)

*Virginia - National Rose Test Garden, Arlington Experiment Farm,

Rosslyn, frlington County, April 2. Collected by Anna E.

Jenkins. (Jenkins)

*Georgia - Augusta, Richmond County, June. 20. (Jenkins)

Crowi canker caused by Cylindrocladium scoparium Morgan

Now York - first report of the disease outside of the greenhouse;

- reported as severe each year and producing a \$2,000 yearly

loss; cuttings placed in cold frame in fall and novered with glass and straw during the winter; Monroe County, May 15. (Massey)

Pennsylvinia - in a greenhouse at Southampton, Bucks County, August 4. This fungus was identified in 1914 from a culture received from . H. Graves, Yale University, which was isulated from the sued bed of the Yale Forest School Nursery. (Jenkins). Prior reports: Georgia; Indiana, Massarhusetts and Now York.

*Indiara - severe loss in one sreenhouse; affected mostly the Butterfly varicty, Princeton, Gibson County, hugust 28.

(Gardner)

+Blight caused. by Dioscoum rosie. Bon.

Florida - found but once in the state; causing. slight injury. ('Veber)

Laf blutch caused by Diplocarpon rosae Wolf, (Actinomela rosac (Iib.) Fr.

Connecticut - Iocal; Hartford County, July 14: (Clinton) 
New York - statewide ran $i, 0$; found on wild uncultivited rose; found by Kirby and Iloney on the inspection of 80 species of roses in a prirk at Rochostur, Suptember 21, te which the following data were cullocted: 12 specs.s. - no infection; 43 species - light infection:

Pennsylvania - (Thurston)

New Jorsey - found in greenhouse; only slight infertion. (Dept. Pl. Path.)

Delaware - more common than usual and causing severe defoli:tion. (Adams)

Kentucky - the following varieties have been free from black spot during the summer and fall in my garden: Madam Butterfly, Climbing merican Beauty', Dr. Van Fleet and Christine Wright. The fullowing varieties have been nearly defoliated: Los ingeles, Tausendsch un, J. Bं. Clark, Wm. R. Smith and Gruss An Teplitz. (Valleau)

South Carolina - locally important. (Ludwig)

Alabuma - important; goneral. (Miles)

Mississippi - probably the most common discase of $r$ sses in the state; it does much damaje to the appearance of the leaves and thus seriously affects the beauty of the cut flowers and rose bushes; some varieties were pparently more susceptible t) the discase than others; satisfactory control of the diseaso was obtained by spraying with 30 rdcaux mixture or ammoniacal copper-carbunate. (Neal \& Jarker)

Texas - (Taubenhaus)

Oklahoma - rather prevalent.. (Stratton)

Ohio - slisht; caused spotting of leaves, Morrow Cunty, July 27. (Detmers)

Indiana - seri jus in grcenhouses. (Gardner)

Kansas - (inito)

Washington - (Heald \& Dana)

Recent literature:

Loge, U. S. i new method of controlling blacksput. Fior. Exch. 57: 437, 469. Feb: 16, 1924. Method of contrul as follows: Sodium carbonate $1-1 / 2$ sunces crystalline salt to one gallon water; or $3 / 4$ sunces anhydr ons to une gallon water with whole jil s rap.

Brown canker caused by Diaporthe umbrina Jenkins

Report prepared by inna E. Jenkins, Office jf Plant Disease Survey and Pathulogical Cullections.

Erown canker was first observed in the form of s.tem cankers in the National Rose Test Garden int irlington Fxperiment Farm, Virginia, in ipril 1917 (Journal of fgricultural Research 15:593-600. 1918). The disease has been under observation sine thet time and hes been found tu occur on most of the other pirtis of tho plant above the ground. The presence of the disease iri the Test Garden is also mentioned in an article by Clarence $\mathrm{i}$. Lintz in the Flurist's Exchange 55: 16-38, Juno 9; 1923. In June 1923 specimens of brown cankor were collected in the experimental perfume rose gardens of tho office of Drug, Poisonuus and Oil Plant Investiutions. It was also joserved on cuttings in a propagation bed in one of the \&rencuses. Where this has been under observation it has pruvad one of the most 


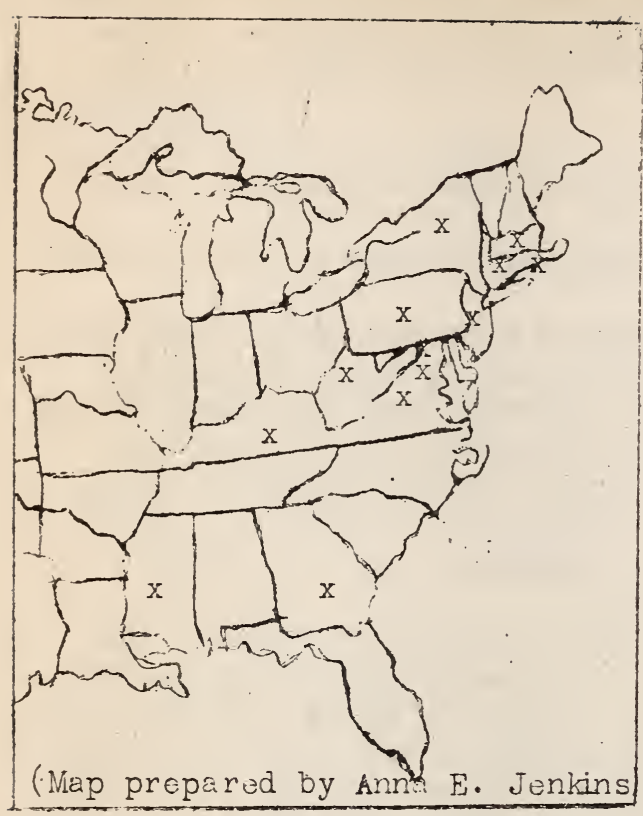

Fig. 16. Prosent known distribution of brown canker of roses. important rose diseases, the borticultural varieties beine particularly susceptible." It seems likely that brown canker may be the cause of serious loss in nursuries as woll as in ruse gardens and that plants affected with it are often not rec jenized as diseased and cunsequently have been widely distributed.

Suggestions for tho oontrol of the disease were given in the paper on brown canker reforred to in the preceding page. From further observations on the nature of the discase the importance of excluding the pathogene from healthy gardens is emphasized. Experiments designed to show whether initial infection on canes jf the current year may be prevented by keeping this gruwth covered with a fungicide ere in progress at the Nati unal Rose Test Garden. The results of the season's experiments are promising. The results of the seas un's spraying experiments showed that certain very susceptible varie-

ties remained healthy while unsprayed plants of the same varicties were as usual hervily infected.

No systom tio survey to determine the geographical distribution of brown canker has been made, but from a study of the specimens menti sned below it is definitily known to have occurred in certain states east of the Mississippi River and indicated in Fig. I6.

Diagnoses of the disease have been made from specimens of affected stems, Iuries and blossims received from the followine statos: (Unluss otherwise stated tho fungus was present un the stem).

Connecticut, New Canaan, 1917 :

District of Culumbir, une c Jllectiun was made May 30 , 1903. On Jure 19, 1922 a garden was visited in which all of the hrbrid r ses were very severely affected and sume of the plirits hed diod. On June 28, 1923 the discase was cullecte from nutted plints of the variety Lady hshton on sale at a florist shop; these bushes. wore said to have been obtained fr m in nursery in Perns. Ivania absut two months previous and were boing sold for sutdor planting.

Goorgir, Cjlumbus, spril 1917. Atlanta June 19, 1923 ( or un uponed bids).

hentucky, ishland July 2, 1920.

Maryland, Juie, April 25, 1923; the plants appeared healthy in the previ jus fall, but many of them were dyinback to the gr and in the spring. Bell station, June 8, 1920 and March 21 and Ostsber 25, 1923. (Cullected on several different varieties.) 
Massachusetts, fmherst, May 1921. The canker was very common on hybrid roses abjut imherst. It was very destructive and in one garden had necessitated a severe cutting back of the canes.

Mississippi, Mendenhä11, June 14, 1919.

New Jersey, New Brunswick, Ort jber 5, 1917. Frmed ¿ spot on leaflets of the Prairie Rose (Rosu setisera). New York, Culd Spring on the Huds on, June 24, 1923.

Pennsylvania, Greoncastle, ipril 25, 1922, Westchester, May 29, 1922.

Rhude Is land, Rockland; June 28, 1922. On the bloss.ums. Batrytis cinerea also present. It may be stated that but bijht jf roses is commonly attributed to Butrytis cinerea, but it has been observed that the infection by the Diaportha fungus may precede the devel opment of the more conspicusus 3 otrytis. In the case of the specimen from Rhode Islund the tr ruble had been diegnosed as blossom blight saused by Butrytis cinerea, but a careful examination showed pyonidia jf Diaporthe umbrina were als J fruiting on the petals.

Virginia, Chatham, May 15, 1915; Ivy Dept, June 17 and March 19, 1921 (in one garden a very finc ovllection of roses had been severely attacked by the blight, the disease was reported as jocurring on stem of jld wodl. Upton, June 1, 1919; Stevensburg, June 3, 1923 (on unopened bloss omsl; Rosslyn, Arlington Experimental Farm 1917 to 1923. Twig blight caused by Gloeosporium rosae Hals:

+Florida - apparently well scatterod but not 'Jf a serious consequence. (Weber)

Prior reports: *District of Columbia, *Indiana, *Luisiana, Maryland,

Mississippi, New Jersey; Ohio. Oklahoma, *Pernsylvania, South

Carolina, Virginia and West Virginia.

Anthracnjse caused by Gloe.jsporium sp.

*Virginia - on Rosa sp. variety Marguerita Dickson; National Rose

Test Garden, Arlington Experimut Faru, . Rosslyn, Arlington

County, March 22; perfect stage devel sped in the cultures made. (Jenkins)

Root knot caused by Heter jdera sp.

How Jorsey - infested plants show no apparont reduced vigor; small

knots are formed on rootlets; in a.greenhouse. (Dept. Pl. Path.) Canker blight caused by Leptosphaoria coniothyrium (Fckl.) Sacc.

(Coni thyrium fuckelii Sacc.)

Now Jersey - cankcrs form graft ceusing the death of scion; reported a $15 \%$ infertion in a greenhouse. (Dept. PI. Path.)

Mississippi - serious in many plantings; jeneral over state;

Oktibbeha County, April 7. (Neal \& Barker)

Texas - (Taubenhaus)

Prior reports: Califurnia, Colorado, *District of Columbia,

Indiana, Iowa, Kansas, *Marylond, *Massachusetts, Michigan,

Minnesota, *New Jersey, North Crrolina, Ohio, *Pennsylvania,

South Carolina, *Texas, *Virginia and West V 1 rginia.

Rot rot causea by Ozonium omnivorum Shear

Texas - prevalent; 3\% Ioss. (Taubenhaus)

+ Leaf blotch caused by Pestalozia compacta Sacc. 
Florida - caused considerable defoliation; well scattered but not sevcre. (Webor)

Rust caused by Phraimidium spp.

New York - probably statewide; found on wild and cultivated roses; "zmong 60 sivei-; in a Rochester Park found only on Rosa alba by Kirby anj Horey; very severe in Tiosa County; Ulster County, June 3 . (Chupp)

+South Carolina - unimportant, Marion County, July 31.

North Dakota - on wila roses; common. (Weniger)

Minnesota - Cott mwood, St. Louis and Wabasha Counties. (Dept. PI. Path.)

Colorado - first time this has been collected on cultivated roses at Ft. Cullins, Larimer County, July. (Learn)

California - Santa Ana, Orange County, September 5; common. (Harter \& weimir)

Leafspot cuused by Phyllosticta rosae Desm.

Delaware - usual prevalence observed and associated with defoliation in many instances. (Hdams)

Liafspot causca by Phyllosticta rosicola Massal.

INew Jersey - New Srunawick, Middlesex County, September 5. (Dept. PI. Path.)

Ramularia macrospora Fres.

*District of Columia - Department of Agriculture Greenhouse, Propajation Grounds; aiseased conditions observed in the autumn of 1923; symptoms remarkably like those of brown canker; Ramularia macrospora Fres. fruiting on roots and crown of plants examined; fungus isolated and grown in pure culture; comparative altural stuaies with crown canker oreanism have been made. (Junkins)

+Canker caused by Septoria rosae Desm.

Mississippi - produces a canker on the stem in association with Coniothyrium; Oktibbeha County, April 7. (Neal \& Barker) + Irafspot caused by Septoria rosicola Desm.

South Carolina - unimportant; Edgefield, Edgefield County, June 12.

( Luciwis)

Powdery mildew caused by Sphaerotheca spp.

Roported from Connectinut, Now York, Pernsylvania, New Jursey, Delaware, Kentusky, Sou.th Jarolina, Florida, Mississippi, hIabama, Louisiana, Tuxas, Oklahoma, Ohio, Indiana, Minnesotä, Konsas, Colorido, Arizona, Washington and California.

At Roshester, Ifew York, Kirby und Honey made an inspection of 80 sponis oi roses at a park september 25 , at which the followini a:ta was collertad,

$$
\begin{aligned}
& \text { Dupros of infention } \frac{\text { No. of species }}{\text { Nione }} \\
& \text { Hocierate } 2 \\
& \text { Heivy } 0 \\
& \text { Viry heavy } 0
\end{aligned}
$$

In Kunturky out of 9 varieties examined by vallesu in his gaiden during the summer and fall the Lus ingeles variety was the only one injured by the mildew. 
Chlorosis ciused by too much lime

Texas - prevalent. (Taubenhius)

Mosaic - cause uniknown

.Connecticut - Marchioness of Dufferin variety affented; not on the other varieties; do not know if infectious; new host to state; Hartford, Hartford County, July 14. (clinton)

Miscellaneous causea.l organisms

Virginia - Rosslyn; in greenhouse at frlington Experimental Farm, Arlington County, Spring; collected by Anna E. Jenkins. The following fungi were present on diseased cuttings in propaEation bed: Coniothyrium sp., Dothiorella sp., Gloeosporium sp., Botrytis sp., Phomops is sp. and Diaporthe umbrina J. (on greater part of affected cuttings). (Jenkins).

Recent Iiterature:

Barker, H. and D. C. Neàl." Cankers (Septoria rosae, Coniothyrium fuckelii, Botrytis sp. and apparently several other fungil. Quart: Bul. Miss. State P1. Bd. 3: 13-34. Jan. 1924.

Darlington, H. R. A preliminary note on a new rose disease. Rose Annual Nat. Rose Soc. 181-184. 1923. "The fungus, which is apparently the cause of the disease, permeates the soil principally as thin cotton-like strands, and where there is manure occurs as a greyish-white powdery film. So:far the identity of the fungus has not been ascertained, nor whether it is really the cause of the discase."

Edgerton, C. W. Rose diseases in Louisiana. Louisiana Agr. Exp. Sta. Extension Div. Cir. 62: 1-8. 1923.

Ramsbottom, John. The earliest description of a rose disease. Rose innual Nat. Rose Soc. 163-170. 1923.

Shelley, A. D. G. Winter spraying. Rose hnrual Rose. Soc. $62-64.1923$.

Horne, Essig and Herms. Cold Injury. California Agr. Exp. Sta. Cir. 265: 1-104. June 1923. "Many plants are found in spring with dark-stained leaves of small distorted and sickly foliage, due to chilling of tender tissue of shoots, which start srowth too early in winter. Delay pruning until February or later. Prune rather heavily and stimulate vigorous growth by general culture measures."

\section{RUBUS ODORETUS}

Powdery mildew caused by Sphaerotheca humuli (DC.) Burr.

New York - Tompkiris c Junty, July 22. (Chüp)

Fly speck cause undetermined

New York - Céttarausus County, June 25. (Chupp)

Mosain - cause undetermined

New York - Tompkins County, June I. (Chupp)

\section{SMIIfiX (Smilax sp.)}

Rust caused by Puccinia smilacis Schw.

*+Florida - common bit not serious. (Weber)

Prior reports: *Alabama, *Arkansas, *Delaware, *District of Columbia, *Georgia, *Kansas, *Kentucky, *Lou isiana, *Maryland, *Mississippi, *Nebraska, *New Jersey, *North Carolina, *Ohio, *Oklahoma, *Soutin Carolina, *Tennesses, *Texas, *Virginia and*West Virginia. 
SNAPDRAGON (Antirrhinum spp.)

Anthracnose caused by Colletotrichum antirrhini Stew.

New Jersey - severe under glass at. Mt. Holly; attacks seedlings causing early de th; 125,000 plants affected; Mt. Holly,

Burlington County, November 22. (Dept. P1. Path.)

+Mississippi - severe; Jones County, June 22. (Neal \& Barker)

Prior reports: Connecticut, Delaware, Indiana, *Maine, *Massa-

chusetts, Michigan, *New York, Ohio, Pennsylvania, and.*Bhode

Is land.

Leafspot caused by phyllosticta ant rrhini syd.

*+New York -' severe locally, Westchester (May 12), Tompkins (May 15),

Counties. (Chupp)

Prior reports: Indiana, Massachusetts and *Virginia.

Rust caused by Puccinia antirrhini Diet. \& Holw. (Dicaeoma antirrhinii)

Connecticut - Bristo1, Hartford County, July 20. (Clinton \& Hunt)

New York - occasionally very serious; $100 \%$ infection at times; reported from four counties; in three flower beds at Ithaca, the percentage of infection was 5,15 and $75 \%$ respectively; Westchester County, May 12. (Chupp)

Pennsylvania - Beaver County. (Thurston.)

Delaware - much less prevalent than usual; sulphur dust has given effective control; Newark, July 6 .' (Adams)

+Kentucky -"both in 1922 and this year appeared about September 1 in my garden; later some of the plants were nearly completely defoliated; in both cases the plants were raised from seed and all 1922 plants were destroyed in the fall." (Valleau)

Ohio - of slight importance; local; most serious as a greenhouse discase; in open the discase appears in late summer, shortening the blooming season; Wooster, Wayne County, August 15. (Young)

Indiana - very serious both in field and greenhou:e; more serious outdours because it carnot be controlled; in greenhouse careful watering prevents spread. (Mains); Loganport, Cass County, June 22. (Gardner)

+Jisconsin - minor importance; Madison, Dane County, July 10. (Vaughan)

Kansas - present quite generally over the state and causing death of snapdragons in the gardens. (White)

Washington - Asotin, Thurston and Pierce Counties. (Heald \& Dana)

Recent literature:

Butler, 0. Fxperiments on the field control of snapdrag on rust together with a description of a method for the control of the disease in greenhouses. 'New Hampshire Agr. Hxp. Sta. Tech. Bul. 22: 1-14.' 1923.

Horne, Essig \& Herms. Puccinia antirrhini in California. California Agr. Exp. Sta. Cir. 255: 1-104. June 1923. McCallán, E. A. Snapdragon rust. Agr. Bul. Bermuda Dept. Agr. 2: 7. 1923 .

\section{SNOWDROP (Ga lanthus nivalis)}

Smut caused by Urocystis galanthi Pape

Recent liturature:

Pelpe, H, Fin neuer, auf Schneeglóckchen (Galenthus nivalis L. ) schmarotzender Brandpilz (Urocystis galaitri Pape). 
A new snut (Urocystis galanthi) parasitic on the snowdrop (Galanthus nivalis L.) Arb. Biol. Reichsanst. fur Land und rorstwirtsch. 11: 331-336: 1923.

SWEET PEA (Lathyrus odoratus)

Streak caused by Dacillus Iathyri: Manns \& Taub.

+Pennsylvania - Lelaware County: (Thurston)

Prior report: Delaware.

Anthracnose caused by Colletotrichum pisi Pat.

+South Carolina - the disease became very destructive during April

in a few small beds at Quincy, Gadsden County; early in April

it began at one end of the bed and workea across, the younger portions of the stems being most severely attacked; that

part above the lesions dying quickly. (Tisdale)

Prior report: *Georgia:

Powdery mildew caused by Erysiphe polygoni DC.

+New York - collected at Riverhead, Long Island County, June I by

Messer, Guba and Rhinebeck. (Chupp)

+North Dakota - unimportant. (Weniger)

Root rot caused by Fusarium sp. et al

New York - serious; probably statewide; 3 to $5 \%$ loss Tompkins County,

October 3. (Chupp)

+Wilt caused $b_{; /}$Fusarium lathyri Taub.

North Dukota - fairly comnon; general; 10\% loss. (Weniger)

+Wilt and stem rot caused by Fusarium vasinfectim Atk.

Florida - reported as the cause of the loss of $5 \%$ of the sweet

peas in several gardens. (Weber).

Anthracnose caused b! Glomerella cingulata (Stonem.) S. \& v. S. (G.

rufomaculans Berk.) Sp. 㕠 v. Schr.)

* +South Carolina - a severe epidemic in the northwest corner of the state in late May and early June during a period of warm moist weather it blooming time. (Ludwig)

+ Florida - caused considerable leafspotting; Hillsborough, Gasden County. (Weber)

+Alabama - important locally in Lee County where an entire planting was absolutoly destroyed, the young growth being blighted before buds rould open. (Miles)

+Mississippi - very surious during year; leaves, stems and flowers affected; general over state; frequently a typical "blight";

Lawrence Courty, May 15. (Neal \& Barker)

Powdery mildew caused by Microsphaera alni (Wallr.) wint.

New York - The following table indicates the degree of infection found in vurious counties:

\begin{tabular}{|c|c|}
\hline County & - Degree of Infection \\
\hline $\begin{array}{l}\text { Bronx } \\
\text { Dutchess : } \\
\text { Suffolk : } \\
\text { Cortland : } \\
\text { Broome : } \\
\text { Livingston: } \\
\text { Otsego : }\end{array}$ & $\begin{array}{l}\text { Trace in greenhouse; scvere locally, May } 12 . \\
: \text { Infection general on foliage; common in } \\
: \text { greenhouses. } \\
: \text { Counts show } 100 \% \text { plants infected and nearly } \\
: 60 \% \text { plants in one greenhouse. } \\
: \text { Common. } \\
: \text { About } 5 \% \text { of loss in one ten-foot row. }\end{array}$ \\
\hline
\end{tabular}


Powdery mildew caused by oidium sp.

Louisiana - this mildew is usually vory common hore in the spring; this is one of the few powdery mildews. that will form the ascogenous stage in the state and is not always that this one does, March 6. (Fidgerton)

+Wilt caused by Pythium spp.

Connecticut - forms two different fruiting bodies, the out of doors one being different from that of the greenhouse; Westport, Fairfield County, January. (Clinton \& McCormick) Rhizoctonia discase caused by Rhizo tonia.sp.

Pennsylvaria - found in greenhouse. (Thurston)

Washingtion - WaIla Walla Cjunty. (Heald \& Dana)

Prior reports: Connecticut, Massachusetts, Michigan, Minnesota, North Carolina and Ohio.

+Wilt ciused by Sclerotium rolfsii Sacc.

Florida - caused the wilting and death of the host plant at st. Augustine and vicinity." (Weber)

Mosaic - cause undetermined

+New York - a local planting showed a 40\% injury; Tompkins County, July 8. (Chupp)

+Wisconsin - a limiting factor in sweet pea culture; general about Madison and Racine where gardens have been examined; probably has been seen for some time; investigations on nature and comparison with other mosaic discases is underway. (Vaughan \& Jones:)

+New Mexico - common on garden sweet peis in Mesilla Valley causing a dwarfing and stunting of the plants; caused a $5 \%$ reduction in yield. (Crawford)

Prior reports: Massachusetts,. Ohio, Pennsylvania and *Virginia. Wilt or stern rot - cause undetermined

South Carolina - important about Aiken, Aiken County, May 9. (Iudwig) Soil trouble caused by excessive nitrogen

Washington - in a gruenhouse. (Heald \& Dana)

SINOVBERRY (Symphoricarpos racemosus)

Powdery mildew caised by Microsphaera diffusa Cke. \& Pke.

*+Oregon - not uncommon; Odell;, Hood River County, July 25. (Boyce)

Prior reports: *Idaho, New Lork and *Washington.

SNO IBFRRY (Symphoricarpos sp.)

+ Fruit rot causod by Botrytis sp.

New Yorh - Ithaci, Tompkins County. (Chupp)

Powdery mildew causod by Microsphicra a iffusa Cko. \& Pk.

+Now York - obs rved on Symphorionrpos ricuosus and $\underline{S}$. vulgaris; Wyoming County, August 24. (Chupp)

Prior reports: On the former in *Iduho, *Oregon and Wushington, and on the latter in Indiana, *Kansas, *llissouri, Texas and *Virginia.

SYRINGA (Philadelphus sp.)

+Loifspot causud by Sphaeropsis syringae (Fr.) P. \& C.

*IeW York - collected by W. D. Mills at Hicksville, Nassau County, August 10. (Chupp) 
Washington - found on stalk; bulbs from Holland, Whitman County. (Heald \& Dana)

Botrytis blight caused by Sotrytis tulipae (Lib.) Hop.

*New York - Whetzel reports "the fungus chiefly attacks base of stalk next to bulb after leaves are fully expanded; the leaves first turn purple then slowly wilt; buses of stalks deup in soil covered with the minute sclerotia; this purpling symptom appears not to have been noted by Hopkins"; Tompkins County, May 11. Kirby inspected the tulip planting at Rochester Park and found Butrytis on the following species: fosturiani - 90\% infected; gesneriane - 100\% killed

greigi $50 \%$ killed

hegeri - $40 \%$ infocted; none kilied

\section{linifolia}

\section{suave jlens}

kaufmanniana - $80 \%$ infected; $30 \%$ killed

primulira - 100\% infected; tubergiana - 100\% killed $50 \%$ dead

+Bulb rot caused by Rhizoctonia tuliparum (Klebahn) Whetzel \& Arth.

(Solerotium tuliparum Klebahn)

New York - confined to tulip planting on an estate in Wostchester

County; $93 \%$ were destroyed in infested soil; this is prob-

ably the first report of this aiscase in America; common in

Hollanà and Germany, April 29. (Chupp)

Recent liter ture:

Whetzel, H. H. and John M. Arthur. The grey bulb-rot of

Recent literature:

tulips. (Abstract) Phytopath. 14: 30. Jan. 1924.

Mackintyre, P. Baroness. Tulip disease. Gard. 45: 381. June 1923.

VERBENA (Verbera sp.)

Powdery milaow caused by Erysiphe oichoracearum DC.

+New York - reported on Verbena hastata and $\underline{V}$. urtioaefolia, Geneseo

County, fugust 22: (Chupp)

Prior reports: For the former species, *District of Columbia,

*Illinois, Iowa, Minnesota, Missouri, *Montana, *Ohio and

* Wisconsin. For the latter, Alabama, Illinois, *Indiana, Iowa,

*Kansas, Minnesota, Missuri, *Now Jersey, *Ohio and *Pennsylvania.

+Mississippi - rather sorious in sev ral greenhouses in the state; Sunflow: County, May 1.

VERONICA ARVTISIS

+Downy mildew culased b" Pronospora grison ung.

New York - Tomphins Cuunty, June 10. Collected by H. H. Thetzel. (Chupp)

$U$

VIBRRNUM (Viburnum sp.)

Bud galls cause undetermined

New York - found in greenhouse; one patoh in the border showed considerable infestation, December 4 . Collected by R. E. Horsey. (Chupp)

VINCA (Vinca rinur)

+Learspot causcd by Phyllosticta vincae-majoris Allesch.

IJew York - Monroe County, September 19. Collected by E. F. Guba.

(Chupp) 
VIOLET (Viola spp.)

Leafspot caused by Alternaria violae Gall. 8. Dorsett

* NeW York - present in bods in grcenhouses; E. F. Guba reports as follows: "causing spots and eventually killing entire blade; spots pale, beginning usually at the margins of the leaves." (Chupp)

Mississippi - general; epidemic in some localitics causing most of

the leaves to be killed, Sunflower County, April 28.

Prior reports: *Georgia and *Maryland.

Luafspot caused by Cercospora violaf Sacc.

*+New York - Otsego County, Hugust 26. Collected by K. H. Fernow. (Chupp)

*Floridu - collected at several places in Gain sville where it caused 20 to $60 \%$ defoliation. (Weber)

Prior reports: *Georgia, *Illinois, Iowa, *Luisiana, *Massachusetts, *Minnes uta, *Nebraska, North Carolina, Ohio, Pennsylvania, *South Carolina and Texas.

+ Leafspot caus d by Collototrichum violne-tricoloris Sm.

New York - Big Indian, SIide Muntuin, Ulster County, June 10. Collected by $\mathrm{E}$. F. Guba. (Chupp)

Leafspot cuused by Marssonia vijlae (Pass.) Succ.

+Minnesota - (Sect. PI. Patr.)

Prior reports: *Comontinut, *District of Columbia, New Jersey and *Vermont.

Leafspot caused by Phyllosticta vijlae Desm.

Floride - caused considerable spotting of loaves; not serious. (Weber)

+A labama - unimportant; roported abunäant each year in outdoor beds

but cortrilled by repeated sprayings of Burdeaux mixture. (Miles)

tKansas - on cultivated violets; slight importance; Kansas City, Wyandotte County, Ootjber 24. (White)

Prior reports: *California, Connecticut, I wa, *licssachusetts, Minnesota, Mebraska, *New York ind South Carjlina.

Rlist caused by Puccinia violae (Schum.) DC.

+New York - roportod on tho fullowing species: +Viuln canadensis, $+\underline{V}$. papiliunacea, and +V. Striata; Ulster County, May 17. (Chupp) Minnesota - Redwod County. (Sect. PI. Path.)

Prior reports: Alabama, California, Culorido, Delaware, District of C Jlumbia, Idaho, Illinois, Inảiana, Iowa, Kansas, Maine, Maryland, Massachusetts, Minhigan, Minn zsota, Mississippi, Miss uri, Montana, Nebraska, Nuw Ha pshire, New Jersey, North Dakota, Ohis, Oregon, Pennsylvinin, South Carolina, Utah, Vermont, Virginia, Washington, Weet Virginia, Wisconsin and $i$ \%oming.

Mosuic - cause undetermined

New York - on the o Jllege cumpus; Ithaoi, I'mpirins Cunty, September 8. Cullected by E. F. Guba. (Chupp)

Prior report: Calif ornia.

VIRGINI CREFPER - See Ampelups is ưuinquef Jia

WIGPIA (Neigolia sp.)

tCrown gall causcd by Banterium tumofaciens EFS. \& Town.

Mississippi - light infuction in a nurscry; Coshoma Cunty, April 27. (Nual \& Barker)

+Rost knot caused by Heterodera radicic la (Groef.) Muell.

Mississippi - hoavy infention in nursery; Cushum County, rppil 26. (Neal \& Barkor) 
YUCCA ( Yruca .sp.)

Leafspot oaused by Coniótiyrium cuncentricum (Desm.) Saco.

* +New York - reported on Yucca filamentosa; Suffolk County, June 1, Dutchess Cunty, August 31 . Colleoted by E. F. Guba. (Chupp)

Prior reports: *Idaho, Indiana, *Iowa, *New Jersey, *North Dakota and * Virginia.

ZINNIh (7innia elegans)

+ Wilt caused by Bacterium sp.

Florida - destroyed plants in Orlando; wás not reported elsewhere. (Weber)

Leafsout caused by Cercospora atricinta Heald \& Wolf

+Florida - collected at Gainesville and Micanopy', where it was

causing partial defoliation. (Weber). Prior report: *Texas.

Powdery mildew caused by Oidium sp.

South Carjlina - unimportant. (Iudwig)

Florida - found to be very cummon on the host plant; it was the the factor limiting the longevity of bloming time; it was of much cuncern to florists. (Weber)

Texas - (Taubenhaus)

Californic - common; Santa Ana, September 5. (Harter \& Weimer) Miscelianevis literature reports:

Jones, S. I. If history of Rhytisma acerinum (Preliminary accountl. Arr. Bot. 37: $731-732$. Oet. 1923.

Wils on, Malcolm. Puccinia mirabilissima Pk. A new British Record. - Trans. \& pruc. Bot. Soc. Edinburgh 28: 164-167. 1923.

\section{- DISEASES OF MISCELLANEOUS PLANTS}

ACORUS CALAMUS (SWeet Fiag')

Leafspot caused by Septocylindrium aromatioum Saco.

* +New York - Labrador Iake, Cortland County, June 30. Collected by H. H. Whetzel. (Chupp)

Prior reports: *Delaware and *New Jersey.

AGRIMONY (Agrimuria spp.)

Rust caused by Pucciniastrum agrimuniae (Diєt.) Tranz.

* New York - Madis on County, August 25. Colleoted by K. H. Fernow. (Chupp)

Prior reports: *rirkansas, Connecticut, *Delaware, *District of Columbia, *Illinois, *Indiana, *Iowa, *Kansas, *Maryland, *Massachusetts, *Minnesota, *Mississippi, *Nebraska, *New Jersey, New Mexico, *North Dakota, *Ohio, *Pennsylvania, *Vermont, *Virginia, *West Virginia and *Wisconsin

+Powdery mildew caused by Sphaerotheos humuli. (DC.) Burr.

*New York - general; Erie County, June 25. (Chupp)

+Mosa ic - cause unknown

New York - Nassau C Junty, June 11. (Chupp)

AGROSTIS PALUSTRIS (Red Top)

Smut oa:used by Ustilag? striaeformis (West.) Niessl.

*+New York - Ithaca, Tumplins Cunty, May 17. Collected by R. S. Kirby. (Kirby) 
Prior repurts: *Illinuis, Indiana, *Iowa, *Maryland, Minnesota and *Virginia.

\section{ALLIUM TRICOCCUM (Wood Leak)}

Leafspot saused by Septoria alliorum Westd. (S. viridi-tingens Curtis)

*+New Yurk - fuund near Labrador Lake, Cortland County, June 3.

Collected by $\mathrm{H}$. H. Whetzel. (Chupp)

Prior reports: Minnesota and *North Dakota.

ALS INE, MEDIA

Leafspot caused by Septoria stellariae Rob. \& Desm.

New York - Tompkins County, October 8. Collected by E. E. Honey. (Chupp)

\section{A LTHAEA. CANNABINA L. (Marsh-mallow)}

+Ascochyta althaeina Sacc. \& Biz.

*New York - common; caused defoliation of lower leaves; Dutchess County, August 31. Collected by E. F. Güba. (Chupp)

AMARANTHUS RETROFIEXUS (Green Amaranth) (Red Ruot) White rust caused by Albugo bliti (Biv.) Kze., (Cystopus blit' (Biv.) Iev,)

+New Yurk - statewide; very common wherever the weed is found; Onondago County, Jurie 30. (chupp)

+New Jersey - Middlesex and Essex, September 25. (Dept. PI: Path.) +Mississippi - géneral; Oktibbeha County, June 24. (Neal \& Barker) +Florida - collected at Vers and Gainesville; caused partial defoliation of host. (Weber)

Minnesota - Brown County. (Sect. PI. Path.)

+Oklahoma - prevalent, Payne County. (Stratton)

* +Colorado - unimportant; Larimer County, September. (Learn)

Prior reports: *Delaware, *Illinois," *Indiana, *Iowa, *Kansas, *Massachusetts, *Michigan, Minnesuta, *Mississippi, *Nebraska, *New York, *North Dakota, *Ohio, *Oklahuma, *Oregon, PennsylAMARANTHUS vania, *Texas, Washington, *West Virginia and *Wisoonsin.

AMARATHUS SP.

+Downy mildew caused by Peronospora amaranti Ell. \& Ev.

New York - c ommon; 5 to $10 \%$ infected; Niagara County, June 3. Collected by F. R. Perry. (Chupp)

AMBROSIh, ELATIOR (Rag Weed) (Ambrosia artemisiaefolia)

Smut caused by Entyloma compositarum Farl.

+ New York - Seneca County, June 29. (Chupp)

Prior reports: Maine and Massachusetts.

Erysiphe cichoracearum DC.

Prior reports: Alabama, *District of Columbia, *Illinois, *Indiana, Iowà, *Kansas, *Maryland, Minnesuta, *Mississippi, *Miss juri, *Nebraska, *New Jersey, *New York, Ohi J, *Pennsy Ivania and Texas

AMBROSIA, PSILOSTACHYA (Western Ragweed)

Rust caused by Pucoinia xanthii Sohw.

+Minnesota - Anioka County. (Sect. Pl. Path.)

Prior reports: *C Iorado, *Kansas, *Montana, *Nebraska and *North Dakota. 
AMBROSIA, TRIFIDA (Great Ragweed)

+Downy mildew caused by Plasmopara halstedii (Farl.) B. \& de T.

Minnesota - Brown, Cottonwood and Waseca Counties. (Sect. Pl. Path.)

Prior reports: *Illinois, *Indiana, Iowa, *Kansas, *Maryland,

*Missouri, *Virginia and *Wisconsin.

AMBROSIA SPP.

Powdery mildew caused by Erysiphe cichoracearum DC.

*+New York - reported on Ambrosia elatior and A. trifida; Tompkins County, August 30. (Chupp)

+New Jersey - New Brunswick, Middlesex County, September 4. (Dept. PI: Path.)

Prior reports: On the former in IIlinois and Mississippi, and on the latter in Alaska, *Illinois, *Indiana, Iowa, *Kansas, Minnesota, Mississippi, Missouri, *Nebraska, North Dakota, Ohio, *South Dakota, Texas and *West Virginia.

Dodder - Cuscuta gronovii Vilild.

+New York - observed on Ambrosia elatior and A. trifida; found in western part of ste.e; Genesee County, June 27. (Chupp)

AMPHICARPA MONOICA (Hog Peanut)

+Powdery mildew caused by Erysiphe polygoni DC."

New York - Oswego County, September 10. (Chupp)

Rust caused by Synchytrium decipiens Farl:

*+New York - common wherever the hog peanut grows; Tompkins County, June 1. (Chupp)

Prior reports: *Mississippi and *Virginia.

ANEMONE CAIIADENSIS (Meadow Anemone)

Downy mildew caused by Peronospora pygmaea Ung ér

*+New York - Tompkins County, May 20. Collected by M. F. Barrus. (Chupp)

Prior report: North Dakota.

ANEMONE NEMOROSA (European Wood Anemone)

Rust caused by puccinia fusca (Pers.) Wint.

*+New York - Nassau County, June 10. Collected by W. D. Mills. (Chupp)

Prior reports: *Massąchusetts, *Mirhigan, *Ohio, *Virginia and *Wisconsin.

ANEMONE QUINQUEFOLIA (American Wood Anemone)

Rust caused by Pucoinia: fusca (Pers.) Wint.

+Minnesota - Pine and Isanti Counties. (Sect. Pl. Path.)

Prior reports: *Delaware, *Indiana, *Iow日, *Michigan, *New York, *Ohio and *Wisconsin.

ANEMONE VIRGINLANA (TaII Anenome)

Smut caused by Uroeystis anemone (Pers.) Wint.

*+New York - Tompkins County, May 20. Collected by M. F. Barrus.

(Chupp). Prior reports: - Iowa and Texas:

APOCYNUM ANDROSAEMIFOLIUM (Spreading Dogbane)

Leafspot caused by Phyllosticta apocyni Trel.

+New York - Tompkins County, July 4. Collected by Guba and Honey.

(Chupp). Prior report: Iowa. 
ARCTIUM SPP. (Burdock)

+ Leaf blotch caused by Bacillus sp.

*New York on Arctium lappa; Poplar Ridse, Cayuga County, May 28.

Collected by D. Reddick. (Chupp)

Rust caused by Puccinia bardanae Cda. (Bullaria burdanae (Cda.) Arth.

*+New York - reported on firctium lappa and A. minus; Tompkins County; September 11. (Chupp)

Prior reports: On the former: species in the *District of Columbia, Indiana; *Virginia and .*West Virginia, and on the latter in *Connectiout, *Illinois, *Indiana, *Kentucky, *Miohigan, *Missouri, *North Dakota, *Ohiu ard *Wisconsin.

+Mosaic - cause undetermined

New York - reported on Arctium lappa and A. minus; Niagara County, June 3. (Chupp)

ARISAEMA STEWARDSONII (Stewardson Brown's Indian: Turnip)

*+Rust oaused by Uromyces arisaemae Cke. (Ur omyces caladii Farl.)

- New York - Cortland County, June 30. Collected by H. H. Whetzel. (Dept. Pl. Path.)

ARISAEMA TRIPHYLLUM (jack-in-the-pulpit)

+Blight caused by Botrytis sp.

New York - Dutchess Cunty, June 16. Collected by Kirby and Honey. (Chupp)

Rust caused by Uromyces arisaemae Cke.

* New York - Ithaca, Tompkins County, May 14. Collected by Cynthia Westcott. (Dept. Pl. Path.)

Prior reports: Connecticut, *Delaware, *District of Columbia, Florida, *Georgia, *Illinois, *Indiana, *Iowa, *Kansas, Kentucky, *Maine, *Maryland, *Miassachusetts, *Michigan, *Minnesota, Mississippi, *Miss uri, *Nebraska, Ne" Hampshire, New Jersey, North Carjlina, *North Dakota, . *hio, *Pennsy lvania, Rhode Island, *South Carolina, *South Daksta, Vermont, *Virginia, *West Virginia and *Wiscousin.

ARUMi SP. (Árum)

Recent literature:

Cornhill, J. Diseased arums. Gard. Illus. 45: 626. 1923.

ASARUM CAUDATUM (Wild Ginger)

Rust caused by Puccinia asarina Kze.

+British Columbia - is not uncommon; Daisy Lake, rugust 22. (Boyce)

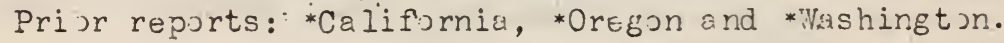

ASARUM SP. (Wild Ginger)

+Root and stem rot caused by Sclerotinia sclerjtiorur (Lib.) Mass.

New York - Cor'tland Cunty, May 19. Collented by K. F. Fernow. (Chupp)

ASC LFPIAS SP. (Milkweed)

Rust caused by Aecidium brandegei Pk. (소. iemesianum Fk.) ( bartholomaei Diet.)

+South Dakota - (Evans')

Prior reports: *Iวwa, *Kansas, *Nebraska and *New York. 
+Mosaic - cause unknown

*New York - reported on Asclepias cornut1; Tompkins County, June 15.

Collected by D. Reddick. (Chupp)

Flagellate infection

Recent literature:

Holmes, Francis 0. A flagellate infection of milkweeds in Maryland. (Abstract) Phytopath. 14: 54. Jan. 1924.

ASTFR CAESIA

+Rust caused by Coleosporium solidaginis (Schw.) Thuem.

* New York - east shore of Cayuga Lake, Ithaca, Tompkins County, May 19. Collected by M. F. Barrus. (Dept. PI. Path.)

ASTER PANICULATUS (Tall White Aster)

+Dodder - Cúscuta gronovil Willa.

New York - Tompkins Cunty, September 1.' Collected by E. E. Honey. (Chuipp)

ASTER PUNICEUS (Swäp:Ảster)

Rust caused by. Puccinia asterum (Schw.) Kern

*+New York - Tthaca, Tmpkins Cunty, May 20. Collected by M. F. Barrus. (Dept. PI. Path.) Prior report: Indiana.

ASTER (Schreberi)?

Rust caused" by Coleosporium sjlidaginis (Schw.) Thuem. +New York - Ithaca, Tompkins County; Miy 10. Collected by M. F. Barrus.: (Dept. PI. Path.)

ASTER STP.

+ Powdery mildew caused by Erysiphe cichoracearum DC.

New York - reported on Asţ̧ laevis, A. lateriflo. us, A. novae-

angliae, A. paniculatus, A. puniceus; Wyoming County, August 24. (Chupp)

Black knot caused by Montagnella heliopsidis (Schw.) Saco.

New York - Tompkins County, May 7\% Collected by H. M. Fitzpatrick.

(Chupp)

+Priyllachora haydeni (B. \& C.) Dearress

*I wa - ooliege nursery, Grinnell. Colleoted by H. S. Conard, Septèmber. (Conard)

Rust caused by pucrinia asterum (Schw.) Kern

New York -..statewide; reported on Aster puniceus; + A paninulatus; +A. corymbosus; Tumpkins County, Miay 20. (Chupp)

ATRIPIEX HASTATA

+ Leafspot causéd by ksciochyta atriplinis Lasch.

New York - Tompkins Cuunty, September 1. Collected by E. E. Honey. (Chupp)

+Leafspot caused by Ramulari A dubia Riess

New York - Tumpkins County, September I. Cullected by E. E. Honey. (Chupp)

BARBAREA VUIGARIS (Wintercress).

+Dodder - Cuscute gronovii Willd.

New York-Orlieans, Ontarij County, June 27. Collected by Kirby and Honey. (Chupp) 
Leafspot caused by Ramularia barbareae Pk.

*+New York - general; Livingston County, May 15. (Chupp)

Prior reports: *Massachusetts, *New Jersey and *Ohio.

BIDENS FRONDOSA (Begcar Ticks)

Powdery mildew caused by Sphaerotheca humuli var. fikliginea (Schlecht.) Salm.

+New York - Tompkins County, August 30. (Chupp)

Prior reports: Indiana, Iowa and Ohio.

BRASSICA ARVENSIS (Char lock)

White rust caused by Albugo candida (Pers:) Kuntze.

+New York - Orleans County, June 26. (Chupp)

Prior reports: *Colorado, Iowa, *Kansas, *Miss ouri," *Nebraska, New York and *North Dakota.

BURSA BURSA-PASTORIS (Shepherds Purse)

Thite rust caused by Albugo candida (Pers.) Kuntz.

*+New York - common; Chenango County, June 14. (Chupp)

+Colorado - Ft. Collins, Larimer County, May. (Learn)

Prior reports: Califomia, Colurado, *Delaware, *District of

Columbia, Geวrgia, *Idaho, *Illinois, *Indiana, Iowa, *Kansas,

*Ma ine, *Massachusetts, *Michigan, Minnesota, Mississippi,

Missouri, * Montana, *New Jersey, *New York, *North Dakota, Iowa, *Ohio, Oklahoma, Wrashington and *Wisc uns in.

Downy mildew caused by Peronospora parasitica (Pers.) DeBy.

+Colorado - Ft. Collins, Larimer County, July. (Iearn)

Prior reports: Indiana, Iowa, Kansas and New Hampshire.

CALLICARPA AMERICANA (American Beautyberry)

Leafspot caused by Cercospora callicarpae Cke.

*+Mississippi - A. \& M. College, September 1. Collected by H. D.

Barker. Prior reports: *Florida and *Texas.

CALTHA PALUSTRIS (Marsh Marigold)

+ Leafspot caused by Cylindrosporium sp.

* Ner York - Labrador Lake, Onondaga County, June 3. Collected by

M. F. Barrus. (Chupp)

Rust caused by Puccinia calthae Link

*+New York - Labrador Lake, Cortland County, June 3. Collected by M. F. Barrus. (Chupp)

Prior reports: Indiana, *Iowa, *Michigan, *North Dakota, *Pennsylvania and *isc onsin.

CAMPANULA GLOMERATA (DanesbI jod)

Leafspot caused by Phyllosticta alliariaefoliae Allesch.

+New York - Tumpkins County, September 8. Collected by E. F. Guba.

(Chupp). Prior report: New Jersey.

CANNABIS SATIVA (Hemp)

Botrytis sp.

Oregon - Salem, Marion County, July. (Dewey)

Virginia - Arlington Farm; th is seems to be a new hemp disease. 
CAREX PENNSY LVANICLM (Pennsylvania Sedge)

Smut caused by Schizonella mela Nogramma (DC.) Schroet.

*+New York - slight; Ithaca, Tompkins County, May 10. Collected by

H. H. Whetzel. (Kirby)

Prior reports: Colorado, Connecticut, *Illinois, Indiana, *Iowa,

*Massachusetts, *Michigan, *North Dakota and Wisconsin.

CAREX STRICTA (Tussock Sedge)

Srut caused by Cintractia caricis (Pers.) Magn.

* +New York - Labrador Lake, Onondaga County, June 30. Collected by

H. H. Whetzel. (Whetzél). Prior reports: Nebraska and Wiscunsin.

CARE: SP. (Sedge)

Rust caused by Puccinia caricis (Scrum.) Reb.

+New York - abundant; Ithaca, Tomp'sins County, July 21. Collected by E. E. Honey: (Kirby)

CEANOTHUS AMPRICANUS (Jersey-tea)

Powdery mildew caused by Microsphaera alni (Wallr.) Wint.

${ }^{*+N e w}$ York - Schuyler County, August 2. Collected by Kirby and Honey. (Chupp):

Prior reports: Connecticut, *Illinois, *Minnesota and *Virginia.

CFLASTRUS SCANDENS (American Bittersweet)

Powdery mildew caused by Phyllactinia corylea (Pers.) Karst.

*+New York - Tompkins. Cunty, October 5. Collected by R. S. Kirby. (Chupp)

Prior reports: Indiana, *Kansas, *Nebraska, *Ohio and *South Dakota. + Fly speck - cause undetermined

New York - Tompkins County, July 4. Collected by:E. E. Honey. (Chupp)

CEPHALAITHUS OCCIDENTALIS (Common Buttonbush)

+Dodder - Cuscuta gronovii Willd.

New York - Tompkins County, September 1. (Chupp)

CENCHRUS ECHINATUS (Sandbur)

+Rust caused by Puccinia cenchri Diet. \& Holw.

Florida - common; not important. (Weber)

Bud blight caused by Ephelis mexicana Fr.

Recent literature:

Weber, George F. Ephelis mexican Fr., Balansia hypoxylon (Pk.) Atk.. on Sandbur, (Cenchrus echinatus L.) (Abstract)

Phytopath. 14: 66. Jan. 1924.

+ Leafspot caused by Phyllochora sphaerosperme wint.

Florida - killed. the older leaves; eommon on poor sjil. (Heber)

CHAETOCHLOA GLAUCA

Smut caused by Ustilago panici-glauci Wint. (U. neglecta Niessl.)

*New York - Ithaca, Tumpkins Cunty, September ll. Collected by R. S. Kirby. (Kirby)

*+Rust caused by Ur myces proeminens (DC.) Lev.

New York - Tompkins County, August 31. Collected by R. S. Kirby. (Chupp) 
CHAMAECYCE MACULUA

* +Rust caused by Ur umyoes ur ueninens (DC.) Lev.

CHAMAECYCE POLYGONIFOLLA

Rust oaused by Uromyces euphorbiae Cke. \& Pk.

*+Iowa - Irikeside Luborat ory, Lake Okoboji, Dickinson County. Collected by H. S. Conerd, July 16 . (Conard).

Prior report: Mississippi.

CHAMAEDAPHNE CALYCUILAAA (Leathërleaf)

Leafspot caused by Venturia pulchella Cke. \& Pk.

+New York - eust side Labrador Lake, On ondaga County, May 19;

sp. questi nned. Collected by E. E. Honey. (Chupp)

Prior roports: *New Hampshire, *New. Jersey and *:Nisc onsin.

CHE LONE GLABRA ('Thite Turtlehead)

Powdery mildew caused by Rrysiohe gal opsidis. DC.

*+New York - Tompkins Cunty, August 11. (Chupp)

Priur reports: *Deluivare and Ohio.

+ Fly sueck - cause undetermined

New. York - Or.taris Cunty, September 22. (Chupp)

CHENOPODIUM ALBUM (mite Guosefoot)

+White rust causad by ilbug, o candida (Pers.) Kuntze.

Mississippi - Tunica County, April 30. (Neal \& Barker)

Downy niluew caused by Peronospora effusa (Grev.) Rabh.

*+New York - Nassau Cunty, June 9. (Chupp). Walton, Delaware County, July 11. Collected by Anna E. Jenkins. (Jenkins)

Minnesota - Hennepin and Co'ttonwood Counties. (Sect. Pl. Path.)

Prior renorts: *District of Columbia, *Illinois, *Indiana, *Iowa, * Kansas, *Massachus etts, *Michioan, *Miss issippi, *North Dakata, *Ohio, *Virginia and *Washington.

CHRYS ANTHEMUM PARTHEN IUM (Feverfew)

Powdery mildew cause undetermined

New York - no report of a mildew on this host either in Salmon's nonograph or in the Plant Path slogy herbarium; found at Castile, Vyoming County, August 25. (Chupp)

CIRCAEA LUTETIANi (Erchunters Nightshade)

Rust caused by Puc?inia ircaeae Pers.

* New York - Ronick Swamp, Tompkins County, July 21. Collected by E. E. Hory. (Chupp)

Prior reports: *California, *District of Columbia, *Illinois, *Indiana, *Iowa, *Kansas, * Miaine, *Maryland, *Massachusetts, *Michicjan, *Minnes ta, *Mississippi, *Nebraska, *New Jersey, *North Dakota, *Orio, *Oregon, *Peninsylvania, *Vermont,

*Virginia, *Washington, *iTest Virginia and *Wiscons in

CIRCAEA PACIFICA (Enchanters Nightshade)

Rust caused by Puccinia circaeae Pers.

+British Columbia - Daisy Lake, August 31. (Boyre)

Priur reports: *Idaho and *Vlashington. 
CIRSIUM ARVENSE (Canada Thistle)

White rust caused by Albug: tragopogonis (Pers.) Grsy

* New York - Onondaga County, September 3. Cullected by K. Fernow.

(Dept. Pl. Puth.)

Prior reports: Minnesota and *Suith Dakota.

Dodder - Cuscuta sp.

+New Yurk - Genesee County, June 27. Collected by Kirby and Honey. (c.upp)

Rust caused by pucninia jbtogens (Ik.) Tul.

* New York - statewide; infection became severe between Júne 15 and June 24; Cortland County, June 3.

Priór reports: *Pennsylvaria, *South Dakota ana *Wisc ons in.

Rust caused by Pucoinia suavejlens (Pers.) Rostr.

* New York - cullected by D. Keddick, May 21. (Chupp)

Prior reports: *Maine, * liassachusetts, *New Jersey, Utah and *Vermont. + Leafspot caus by Septoria cirsii Neissel.

New York - Monroe C Junty, June 9. (Chupp)

\section{CIRSIUM MUTICUM}

White rust caused by Albug o trag jpogonis (Pers.) Gray

+New York - Tompins County, iugust 11. (Chupp). Pri or report: *Ohio.

CLAYTONIA CAROIIIIANA (Carolina Spring Beguty)

+Rust caused by Puccinia claytoniata (Schw.) Syd.

*New York - Ithaca, Tumpins County, May 19. Collected by M. F. Barrus. (Dept. Pl. Path.) Weltun, Delaware County, May 5. Collected by Anna E. Jenkins. (Jenkins)

CODIAEUN VARISGATUM (Croton)

+Leafsnot caused by Gloeosporium sp.

Florida - common over the state. (Weber)

CODIAEUM SP. (Crotun)

+Gloeosnorium crotonis Del.

New Jersey - Riverton, August 4. (Dept. Pl. Path.)

COMANDRA UMBELLATA (Bastari Toad Flax)

+Rust caused by Puccinia andropogunis Schw.

*Iowa - Dickins on County, June 23. Collected by H. S. Conard. (Conard)

\section{COMARUM PALUSTRE}

Mosaic - cause undetermined

New York - Onondaga County, September 15. (Chupp)

CONVOLVULUS SEPIM (Hedge Bindweed)

+Dodder - Cuscuta gronovii Willd.

New York - Tompkins County, September 1. Cullected by E. E. Honey. (Honey)

Rust caused by Puccinia convolvuli (Pers.) Cast.

*+New York - Livinston County, July 14. Coilected by R. S. Yirby. (Chupp)

Prior reports: *Deluware, *District of Culumbia, *Illinois, *Indiana, *Iowa, *Kansas, *Maryland, *Massachusetts, *Michigan, *Minnesuta, *Mississippi, *Miss uri, *Montana, *Nebraska, *New Jersey, *North Dakota, *Ohio, *Virginia, *West Virginia and * lisconsin. 
426

CORNUS CANADENSIS (BWWhWEry)

Rust caused by Puccinia porphyr ggenita Curt.

+Eritish Culumbia - Vancouver, sueust 19. (Boyce)

Friur repurts: *Idaho, *ilaine, *Minnesuta, *IJew Hampshire, *New York, *Uregon and *Washington.

CYPERUS STRIGOSUS (Straw Colored Cyperus)

Rust caused by Puccinia cyperi Arth.

*+Iowa - Dickinson County, Ausust 9. Collected by H. S. Conard. (Conard). Prior reports: Indiana and *New York.

DECODON VRRTICILLATUS (Water Willow)

Rust causod by Pucrinia minutissima Arth.

* New York - very abundant; distorted the plants growing in water al ung the shore; Suffolk County, June 21. Collected by M. F. Barrus. (Chupp)

Prior reports: *Delaware, Indiana, *Massachusetts, *New Jersey, *Ohio and *irisc ons in.

DENTARIA DIPHYLLi (Crinkleroot)

White rust caused by Albuco candida (Pers.) Kuntze.

*+New York - Tumokins County, May 3. (Chupp)

Prior report: Indiuna.

DENTARIA LACIIIATA (Cut Tuothwort)

Down mildew caused by Peronospora parasitica (Pers.) D By.

*+New York - Tompkins Cuunty, May 1Z. Collested by M. F. Barrus.

(Chupp)

Prior renorts: *Delaware, *District of Culumbia, *Illinois, Indiana, Iowa, *Maryland, *Ohi॰, *Virginia and *Wisconsin.

DICENTRA CANADENSIS (SquirreI Corn)

Dopry Inilowew caused by Peronospora corydalis D B.y.

$*+N$ W Y Jrk - Ithaca, Tompkins County, May 8. Colleoted by M. F.

Bärus. (Dept. PI. Path.)

Prior reports: *District of Columbia and *Indiana.

DICENTRA CUCULLARIA (Dutohmans Breonhes)

Dom 1:y mizdew cruseä by Peronospora corydalis D By.

*+Now York - Ithaca, Tumpkins County, liay 13. Collected by M. F.

Barrus. Prior report: Indiala.

DIODIA TEPES (Button Wed)

Rust oauscd by Uroriyous spermarocus (Schw.) Thuem.

* Mississippi - Oktibbuha County, Septemoer 1.5. (Neal \& Barker)

Prior roports: "ilabana, *hrkarsas, De laware, *District of Columbia,

*Florida, *Georgia, *Illinois, *Indiank, *Karsas, *Maryland,

*Missouri, *New Jersey, North Cirjlina, *Oklahoma, *South

Carolina, Tennessee, *Texas, *Virginia and *West Virginia.

FCHINOCYSTIS LOB:TA (Mock Cucumber)

+Mosaic - cause unknown

NuW York - Wy ming County, August 24. Collected by E. F. Guba.

(Cnupp) 
ELEPHANTOPUS TONEITOSUS (Wolly Elephants-foot) (Tobacco Weed)

Rust caused by Cule js jurium elephantopod is (Schw.) Thuem.

* +Florida - c silected near Gainesville, October 1922. (Weber)

Prior reports: Alabama, *irkansas, *Georgia, *Louisiana, Mississip

South Carulina, * Texas and Virginia.

EPIIOBIUM ANCUS TIFOLIUM (Fireweed)

Fir-fircheed rust caused by pucciniastrum pustulatum (Pers.) Diet.

*+Oreg on - abundant, Waldport, Linc.uln County, October 10. (Boy?e)

Prior repurts: *Colorado, Idaho, *Montana, *New York, *North

Dakota, *Washiniton and *West Virginia.

ERECHTITES HIERACIFOIÍ (Fireweed)-

+Powdery mildew caused by Erys iphe polygoni DC.

New Y ork - Tumpkins County, September 1. Collected by E. E. Honey. (Chupp)

ERIGERON ANNUUS (Sweet Scabiuus) (White-top).

Rust caused by Puccinia caricis-erigerontis Arth.

+New York - Cortland County, husust 20: Collected by R. S. Kirby.

(Chupp). Frior reports: Iowa and *Missouri.

ERIGERON,SP. (Fleabarie)

Leafspot caused by Sentoria erigerontis B. \& C.

+liew Y Yrk - Wy ming Count, August 14. Colleoted by E. F. Guba.

(Chupp)

Prior reports: Indiana, *Maryland and*Ohio.

ERYTHRONIUM AMERICANUM (Adder's Tongue) (Common Trout-lily)

Smut caused by Ustilag) heufleri Fokl. (U. erythronii Clint.) (U. tulipae Wint.)

*+New York - swamps; Ithaca, Tompkins County, May 6. Collected by Honey and Perry. (Chupp)

Prior reports: *Delaware, *District of Columbia, Maryland, Missouri, New Jersey and *Pennsylvania.

ERYTHRONIUN SP. (Adder'S TOngue)

+Blight caused by Botrytis sp.

New York - Cortland County, May' 19. Collected by E. E. Honey. (Chupp)

EUPATORIUM PERFOLIATUM (Boneset)

Rust caused by Puccinia . Iexcharidis Arth. (Aecidium compositarum euportii

Det.) (Dicesuma eleocharidis (Arth.) Kuntze)

*+New York - very cummon and injurious near Sag Harbor, Suffolk County, June 21. Coliected by M. F. Barrus. (Chupp)

*+Iowa - Dickenson County, June 23. Collected by H. 3. Conard. (Conard)

Prior reports: Indiana and *Nebraska.

EUPATORIUM PURPUREUM (Joe-Pye-Weed)

Powdery mildew caused by Erysiphe cichoracearum DC.

+New York - Onondaga County, September 15. (Chupp)

Prior reports: *Connecticut, Illiruis, "Indiana and *Wiscorisin.

EUPA TORIUM URTICAEFOLIUM (Snow Thor JuEhwort)

Powdery mildew caused by Erysiphe cichoracearum DC.

*+New York - Onondaga C Junty, September 15. (Chupp) 
Priur repurts: *Distriet if Colmmia, Iowa ard "Nouraska. Rust caused by Puaeinia teruis (Schv:.) Burr.

* +New York - Jortland County, June 30. Collected by H. H. Wretzel. (Chupp). Prior reports: *IIlinois, Indiana, *Masscichusetts, Ohio, Frneylvania and *Wisconsin.

EUFHORBIf SFP. - See Chumaesyre spp.

FUTHANIA GRAMINIFOLIA

Rust crused by Jucuinia cariois-solidnginis Arth.

*New York - statewide; Onondaga County, June 3. (Chupp)

Frior report: Iowa:

FICUS SP.'(Banyan)

+ Leafspot caused by khytisma sp.

Florida - caused alixost ra complete defoliation of host when affected; not common. (weber)

FIOFRKA PROSERPINACODES (False Mermaid)

White rust coused by prityloma floerkede Holw.

*+New York - Labrador Lako, Jortland County, May 19. Colleoted by H. H. The or el. (Chupp)

Prior reports: *Delawse, Indiana, Ohio, *ilest Virginia and

*itisconsin.

GALEPSIS TEIRAHIT var. BJFIDA (Hemp Nettle)

+ Ieafspot caused by Sevtoria galeopsidis West.

Nev York - Dig Indiar:. SIide Mountain, Ulster County, June 7. Coliected by E. F. Guiva. (Chupp)

GAULTHEKIA PROCUMBNS (wintergreen, Checkerberry)

isterina yaultieriae Curt.

* New York - Piverhoad, Suffolk County, June 1. Collected by I. M. liassey and E. F. Guba. (Chupp)

Prior rejorts: *Connecticut, *Maine, *Massachusetts and *Wisconsin. Lerisnot caused by Phyllosticta gaultheriae Ell. \& Fv.

* +Now York - Suffulk County, May 29. Collected by E. F. Guba. (Chunp)

Prior renort: *New Jarsey.

GAURA BIENiIS (Biennial Geurc)

+ Leafsnot caused by C zonspora gaurge Kell. \& Sw.

New Yorl - Tompiris Cunty, September 11. Collected by Kirby and Honey. (chupp)

GERANIUM MACULATLM (TIIa Gerunium)

Rust caused by Fuccinia polyoni-amphibii Pers;

* +ivew York - Tomikins Cunty, July 4. (Chupp)

Prior reports: *Indiana, Iowa," Minnesota, *Mississippi and *Wisconsin.

CERANIUM ROBMRTIANLM (Herb Robert)

Stigmater robrertiana Fr.

* New York - Tompkins County, May 8. Collected by H. H. Whetzel.

(chupp). Prior report: * Massachusetts. 
HF LIANTHUS LONGIFOLIUS (Sunflowor)

+Erysiphe cichorceearum. DC.

New York - Nasiuu County, August 10. Collected by W. D. Mills.

(Dept. Fl. Path.)

HELIANTHUS SCAERRIMUS (Prairie Sunflower)

Plasmopara halstedil (Farl.) B. \& DeT.

*+New York - Nesüury, Nassau County, August 10. Collected by W. D. Milis. (Dept. PI. Path.). Prior report: *Nebraska.

HELIOPSIS SCABRA (RJUGh Helionsis)

+Fuccinia helionthi Schw.

*Iowa - Dickins on Cunty, Jurie 23. Collected by H. S. Conard. (C onard)

HEPATICA ACUTIIDBA (Sharplove Hepatica)

Downy milatew caused by Plasmopara pygmaea (Ung.) Schruet.

+New Yjrk - Onondago County, May 20. (Chupp)

Prior reports: Iowa and *Wisconsin.

HEPATICA TRIIOBA (Roundlobe Hepaticá)

+Downy mildew caused by Plasmopara pymaea (Ung.) Schroet.

*New Yori - Fumkins County, May 7 . (Chupp)

Rust caused oy Iranzsuhelia punctata (Pers.) Arth.

+Now York - Tompkins C Junty, May 2. Collected by H. H. Whetzel. (Chupp)

Frior reports: Delaware, Indiana and Pennsylvania.

HEPATICA SPP.

Smut caused by Urocystis anemones Pers.

* New York - Tompkins cunty, May 6 ; reported on $\underline{\mathrm{H}}$. triloba and $\underline{\mathrm{H}}$. acutiloba. (Chupp)

Prior reports: on the former in Missuri, and on the latter in

*Ilinois, Indisna, Iowa, Minnesota and * "isisconsin.

HESPERIS MATKONALIS (Dames Rucket)

+D wny rildew caused by Puronospora parasitica (Pers.) D By.

New Y Yrk - T Mmpkins County, July 8. Collected by H. H. Thetzel.

(Chupp)

HIBISCUS SABDARIFFA (ROSeIle)

Enthracnose caused by colletotrichum sp.

Florida - Iucsily destructive; Vers, St. Iucie County. (Weber)

HUMULUS LUPULUS (Hop)

thinthranuse caused by Colietotrichum sp.

New York - quite oummu; 80\% of plants infected, but only on a few

leaves per plant; Oneida Cuunty, June 19: (Chupp)

Powdery mildew caused by Sphaerotheca humuli (DC.) Burrr.

New York - c ummon whore sulfur dusting is not practiced; trace to $5 \%$ reduction in yield. (Chupp)

+Mosaic - cause urknown

Now York - Oneida C ounty, June 19. (Chupp)

Recert liternture:

Salnen, .. S. and H. Wormald. A new Cercospora on Humulus. Juir. Bot 6I: 134-136. May 1023. 

milciew (Psexioneronospora humuli, Miyabe and Takah.), Hop leafs?ut, ir Jrop.

HYDROCOTYIE VULAARIS (Marsh Pennyw rt)

+Rust caused by Puccinia hydroostyles (Ik.) Cke.

Floricia - vory common. (Weber)

HYDROPHYLTUM VIZCINIANUM (Virginia water-leaf)

Dowy mildew caused by Deronospora hydrophylli Waite

*+Nuw For - En iileld Gurje, Ithaca, Tompkins County, May 13. (Chupp)

Prior runorts: *Illinois, Iowa and *Visconsin.

+Rust caused ry Puccinia apocrynta EII. \& Tr.

Iowa - Poweshick County, May 22. Collected by H. S. Conard. (Conard)

HYPERICUM VIRGIIICUM - See Triadenum virinicum

IMPATIENS BIFIOAA (Spotted Snapweed)

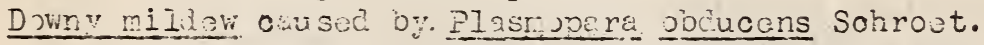

* +lew York - Lobrailur Lake, Cordlard-County, Muy 19. Cullecten by

H. H. Finetzel. (Dopt. PI. Puth.)

Priun report: *Iniina.

+ Rust caused by puocinia perminuta Arth.

*Iuwa - Dickinson Cuunty. Collected by H. S. Conard, July 4. (Conara)

IMDATIENS PALLIDA

Duny mildew caused by Plasmonara obausens Schroet.

+ivew York - Cortland County, liay 19. (Chunp). Prior report,*labama.

IMPRTENS SP. (Snapweed)

Dodur - Cuscute gronovii Villa.

+itew York - Orleans County, Jure 27. (Chupp)

Rust caused. by Fuccinia impatient, is (Schw.) Arth.

* Hew York - Oringe C Junty, June 17. (Chupp)

Prior reports: *Delcware, *District of Culumbia, *Illinuis, *Indiana, *I.wa, *Kansas, *Maryland, *Minnesota, *Mississippi, *Missouri,

*Nouriska, *Ohio, *Pennsylvania and *South Dakota.

INUIA HELINTIM ( I campane)

Powlery nilew callse? Dy Erysiphe oichoranearum DC.

* +liw York - Turmkins County, susust 11. ( Chu $_{1}$ ? $)$

Prior report: iniscousin.

JUNCOIDES C:MPPSTPF (Inzula campestris) (C ommon wod-rush)

Rust causeu by Fucoiniu campestsig Schroet. (Dioiegra ubscurum (Schrjet.) Kuntice?

* +New Yorl - Tompkins County, Niay 10. Collected by H. H. Whetzel. (Chupp). Prior repsts: Indiuna, *Kansas, *ifassachusetts and *Ohio.

LACTUCA CANSDENISIS REGEL (Mili Lettuce)

Downy mi] duv caused by Bremia lactucae

+ivew York - Putnam County, June 27. (C:sup)

Prior reports: Illinois, Iowa, Kansas, Kuntucky, Nebraska and North

Ceru?ina. 
IACTUCA VIROSh (Prickley Wilu Lettuce), (L. scariula)

+Dodder - Cuscuta ronovii Willd.

New York - Genesee County, June 27. (Chupp)

+ Powdery miliew causea by Erysinhe cichoracearum DC.

New York - Tomkins cunty, Sentember 14. (Chupp)

LEPIDIUM CiMPESTIE (Field, Cow or Bastara Cress)

White rust oaused by Albugo candida (Pers.) Kuntze

*Now York - Tompins County, July 14. Collected by H. H. Thetzel.

(Chupp). Prior report: Indiana.

LEPIDIUN SP. (Pepper Grass)

Down milaew causea by Peronjspora parasitica (Pers.) D By.

Florida - collected un this host in Gainesville, bordering a

cabbae patch infected with the disease; the disease was

lentiful and isasterous on this host. (Weber)

Prior report: North Dakota.

LFUCOTHOE RXILIRIS (Duwny Leucothoe).

+ Ierf'sot cause? by Vontiria sp.

Nuw Yorle - Monr Je Cunty, September 21. (Chupp)

LILIUM SPP.

Rust caused by Uroryces holwayi Lain.

New York - Onondaga County, May 19. (Chupp). Reported on Lilium canalunse and L. philadelphicum.

Prior roports: On the former in Maine and on the latter in Now Hainpsiriro.

LUZULA CAMPESTRIS - Sec Juncoides camiestre

LUZULi SP. (WJod Rush)

+Rust caused by Puccinia oblungata (Lk.) Wint. ( P. Iuzuli)

*New York - June 10. Collected by W. D. Mills. (Dept. PI. Path.)

LYCHNIS DIOICA (ReC Campion)

+Rust caused by Uron yces Iychnicis Tr. \& Farle

ivew York - Tominis County, September 20. (Chupp)

LYCOPUS UIIELORUS (Bujleirees.)

+ Rust caused by Puccinia ensustata Pk.

*New York - Onurdetga Cunty, June 30. Collected by H. H. Thetzel. (Dept. Pl. Peth.)

MALVA ROTUNDIFULIi (Dwsirf or Running Mallow)

Leafspot caused-by Macrosporium nalvae Thuem.

+New York - Jama ica, queens Cuunty, June 1l, and Monroe County,

August 22. Collected by K. H. Fernow. (Chupp)

Prior report: Indiana.

Rust causea by Puccinia malvasearum Mont.

Now Yorl - stetewide; Tompkins Cunty, May 29. (Chupp)

Prio: roports: Ariz una, California, Colorado, Connecticut, Delaware,

Inciana, Maine, Massachusetts, Mirh: Ean, New Jersey, New

Mexios, Oregon, Pennsylvania, Utah, Vermont, Virginia, Wash-

ington, West Virginia and Misconsin. 
+Leafspot caused by Septoria heterockrom. Desm.

New York - Wayne County, July 10. (Chupp)

MALVA SP. (Mallow)

Rust caused by Puccinia malvacearum Mont.

+New York - Steuben County, September 6. Collected by M. F. Barrus. (Dept. Pl. Path.)

+Colorado - Ft. Collins, Larimer County, September. (Learn)

Prior reports: California, New Jersey, Oregon and Virginia.

MEIBOMIA CANADENSIS (Desmodium canadensis) (Tick Trefoil)

Powdery mildew caused by Microsphaera diffusa Cke. \& Pk.

*+New York - Tompkins County, .. July 29 . Collected by R. S. Kirby. (Chupp)

Prior reports: *Connectiat, *Illinois, *Iowa, Minnesota, Missouri and *Nebraska.

MENTHA ARVENSIS (Field Mint)

+Rust caused by Puccinia menthae Pers.

New York - Tompkins County, August 11. (Chupp)

MENTHA SPP.

Rust caused by Puccinia menthae Pers.

Florida - found very plentiful in the woods in the vicinity of Gainesville; an aecidial stage was found on the same plants as the telial stage, showing the sluster cups in abundance; the aecial cups developed about a month later than the telial stage and affected leaf blades, midrib and petiole. (Weber)

+Colorado - Ft. Collins, Larimer County, September. (Learn)

N:ENZIESIA FERRUGINEA (False Azalea)

Tar spot caused by Melasmia menziesiae Dearn. \& Barth.

*+Oregon - resulted in little injury to host, Waldport, Lincoln

County, October 9. (Boyce). Prior report: *Washington.

MONARDA FISTULOSA (Wild Bergamot)

Rust caused by Puccinia menthae Pers.

*+New York - Tompkins County, September 8. (Chupp)

Prior reports: *Colorado, *Illinois, *Intiana, *Iowa, *Kansas, *Michigar, Minnesota, *Mississippi, *Missouri, *Montana,

*Nebraska, *North Dakota, *Ohio, *Punnsylvania, "South Dakota,

*Texas, *Virgiria, *Wisconsin and *Wyoming.

MUSA TEXTILIS NEI (Manila Hemp)

Wilt caused by Fusurium cubense EFS.

Recent literature:

Lee, H. A. and F. B. Scrrano. Banena wilt of the Manila hemp plant. Phytoputh. 13: 253-256. May 1923.

NABALUS ALBUS

Pnwdery mildew cau sed by Erysiphe cichoracearum DC.

Now York - Tompkins County, July 8. (Chupp.)

Rust caused by puccinia prenanthis (Pers.) Linur.

New York - Tompkins County, May 28. (Chupp) 
Rust caused by puccinia patruelis Arth. Minnesota - (Ssct. Pl. Path.)

Leafspot caused by Septoria nabali B. \& C. New York - Tompkins County, July 4. (Chupp)

NABA LUS A LTISSTMUS

Rust caused by puccinia orbicula Pk.

Now York - Ithace, Tompkins County, May 16. Colleuted by I1. H. Whetzel. (Ghupp)

OENOTHERA BIENNIS (Common Evening Primrose)

Powdery mildew caused by Erysiphe polygoni DC.

* New York - general; Allegang County, August 14. (Chupp)

Prior repurts: Alabama, *Idaho, Illinois, Iowa, Minnesota, Mississippi, *North Dakota and Ohio.

Downy mildew ciused by Peronospora arthuri Farl.

*+New York - Cortland County, June 3. Collected by M. F. Barrus. (Dept. Pl. Path.)

Prior reports: *Idaho, *Illinois, Indiana, *Iowa, *Kansas, *Maryland, *Massachusetts, Mississippi, Missouri, *Nebraska and $\therefore$ :oriio.

Rust cuusod by Puccinia peckii (DeT.) Kell.

* +New York - Columbia County, June 16. (Chupp)

Minnesota - Beltrami, Altkin and Chisago Counties. (Dept. PI. Path.)

Prior reports: *Califurnia, Iowa, Kansas, Minnesota, *Mississippi,

*Nebraska and *tisconsin.

Leafspot cuus od vy pepturis oenouherce Test

*+New York - Tompkins County, July 20. Collected by E. F. Guba. (Chupp)

Frior reports:-Alabema, *District of Columbia, *Illinois, Indiana,

*Iowa, *Kansas, *Kentucky, *karyland, *Massachusetts, *Minnesota, *Mississippi, Nebraska, *North Carolina, *Ohio, Pennsylvania, South Carolina, *South Dakota and * isconsin.

+Rust caused by Uromyces plumbarius Pk.

New York - Columbia County; June 16. (Chupp)

OENOTHERA SP. (Tetraptera variety childsii)

+Powdery mildew caused by Erysiphe polygoni DC.

New York - Allogany County, August 14. (Chupp)

ONOCLEA SENSIBILIS (Sunsitive Fern)

+Dodder - Cuscuta er onovii willd.

New York - Onundagn County, September 15. (Chupp)

+Rust caused by URedinops/s

New York - Oswego County, September 11. (Chupp)

OSMARONIA CERASIFORMIS (Indian PIUM)

Iieafspot caused by. Septoglocum nuttallii Hark.

+Oregon - sometimes causes premature leaf fall; Rujada, Lane County, June 17; Macleay Park, Portland, Multnomah County, fugust 2.

(Boyce). Prior report: *California.

OSMORRHIZA CLWYTONI (Woolly or Hairy Sweet-cicely)

Rust caused by Puccinia pimpinellae (Str.) Ik.

*New York - Tompkins County, May 14. Collected by E. E. Honey: (Chupp)

Prior reports: Illinois, Iowa a *Wisconsin. 
OSMORRHIZA IONGISTYLIS (Washingtonia longistylis) (Smosther Sweet-Cicely, Anise-root)

Rust caused by Puccinia pimpinellae (Str.) Ik.

*+New York - Tompkins County, May 10. (Chupp)

Prior reports: Illinois, Indiana and Iowa.

OXALIS CORNICULATA (Creeping OXalis)

Powdery mildew caused by Microsphaera russellii Clint.

+New York - Tompkins County, September 8. (Chupp)

Prior report: Indiana.

Lcafspot caused by Phyllos ticta guttulata Hals.

+New York - rare, Genessee County, hugust 22. (Chupp)

Prior reports: Indiana, *New Jersey and *Vermont.

PANAX SP. (Ginserg.)

+Root rot caused by Ramularia sp.

Washington - (Heald \& Dana)

Recent literature:

Nakata, Kákugoro and Sei to Takimoto. Studies on ginseng diseases in Korea. Bul. Agr. Exp. Sta. Chosen 5: 81. 1922. The following new species are desoribed (in English): Colletotrichum panacicola on leaf and stom; Baoterium paraxi, amber rot; Phoma panacis, brown, brown and silvery gray rot on stems; Phyllosticta panax, brown spot of leaves. English abstract in Japanese Jour. Bot. 1: 43-44. 1923.

PARNASSIA CAROLINIAITA (Carolina Parnassia)

+Powdery mildew caused by Erysiphe polygoni DC.

New York - Tompkins County, August 11: (Chupp)

PELIAEA ATROPURPUREA

Rust caused by Hyalopsora cheilanth is Arth.

Kentucky - (McFarland)

Recent literature:

McFarland, F. T. The occurrence of tro fern rusts in Kertucky. Science 58: 186. Sept. 1923.

PELTANDRA VIRGINICA (Virginia Arrow-Arum)

Rust cau sed by Uromyces ari-virginici (Schw.; Howe

+New York - Tompkins County, July 29. (Chupp)

Prior report: *Pennsylvania

PERSICARIA HYDROPIPER (Polygonum hydropiper) (Smart Weed)

Leafspot caused by Septoria polygonoring Desm.

+New York - Tompkins County, June 21. (Chupp)

Prior reports: Missouri and West Vinginia.

PERSICARIA LAPATHIFOLIUM

Leafspot caused by Septoria polvgonorum Desm.

New York - Tompkins County, June 21. (Chupp)

PERSICARIA MUHLENBERGII (Polygonum muhlenbergii) (Swamp Persicaria)

Rust ouuscd by Puccinia polygoni amphibii Pers. 
+New York - Ithaca, Tompkins County, Septemior 6. Collected by R. S. Kirby. (Dept. PI. Path.)

Prior reports:. Iduho, Indiana, Michigan, Minnesote, Montana, South. Dakota, Washington and Wyoming.

PERSICARÍ́ PENISYLVANICA

+ Dodder - Cuscuta gronovii willd.

New York - Orleans County, June 21. (Chupp)

PERSICARIA PERSICARIA (Polygonum persicaria) (Lady's Thumb, Heartweed)

+Powdery mildew caused by Erysiphe polygoni DC.

New York - statewide; Allegany County, August 15. (Chupp)

\section{PHRAGMITES COMMUNIS (TaII Red Grass)}

Rust caused by Pucrinia phragmitis. (Schum.) Kern

*Minnesota - Hemepin County.)(Sect. P1. Fath.)

Prior reports: *Colo rado, *Illinois, *Iowa, *Kansas, *Michigan, *Nebraska, *North Dakota, *South Rakota and *Wiscons in.

PHYSALIS SPP. (Ground Cherry)

+Wite smut caused by Erityloma australe Speg.

New York - appeared in garden in 1922; plants of 1923 were from new seed; fungus evidently stays in the soil. (Whetzel)

Reported on +Physelis francheti, + glabrata, Tompkins County, July 19. (Chupp)

PHYTOLACCA. AMERICANA (DECANDRA) (Common Poke-berry).

+Mosaic - cause undetermined.

New York - Nassau County, June 10. (Chupp)

PHYTOLACCA SP. (Pokeweed, Pokeberry)

+ Mosaic - cause undetermined

*New York - Mineola, Nassai: County, June 10. Collected by N. D. Milis. (Dept. PI. Path.)

Florida - found on tho host plant practically everywhere in the state; the host is widely scattered and they were found to be $100 \%$ infected whether isclated in the thick woods or on the border of oultivated fields. (Weber)

PLANTAGO IIAJOR (Common Plantain)

Powdery mildew caused by Erysiphe cichoraceamim. DC.

* +New York - statewide; Franklin County, July 28. (Chupp)

Prior reports: *Coluradj, *District of Culumbia, Inciana, Iowa, Mirnosota, Missouri, *Montana, *Nebraska, *North Dakota and * Penns ylvania.

Downy mildew causid by Peronospora effusa (Grev.) Rabh.

*+Ner York - Wa jne County, July 9.:(Chupp). Prior report: Iowa.

Leafspot caused by Rumularia plantaginis Ell. \& Mart.

+New York - Tompkirs County, spril 1. (Chupp)

Prior reports: *Illinois, *Inciana, Kentucky, *Maine, *Minnesota, *Nebraska, *New Jersey, *Ohio and *Wisconsin. 
+New York - statewide; Franklin County, July 28. (Chupp)

Prior reports: *Illinois, Iowa and *Nebraska.

Ieafspot caused by Ramiarie plantaginis Ell. \& Mart.

+liew York - Tompkins County, April I. (Chupp)

Prior report: Indiana.

PLANTAGO SPP. (Plantain)

Leafspot caused by Cercospura plantaginis Sacc.

*+Missouri - killed entire plants; Sedalia, Pettis County, July 26. (Burrill)

Prior reports:*District of Columbia and *Kansas.

PODOPHY LLM PELTITUM (Mandrake)

Leafspot caused by Phyllosticta podophylIi (Curt.) Mint.

*+New York - Erie County, June 25. (Chupp)

Prior reports: Alabama, Delaware, *Illinois, Indiana, Kentucky,

*Mississippi, Missouri, *Ohio and Pennsylvania.

Rust caused by Puccinia podophylli Schw.

* Hew York - Tompkins Cuunty, May 8. (Chupp)

Prior reports: Alabama, *Delaware, *District of Columbia, *Illinois,

*Indiana, *Ijwa, *Kensas, *Iouisiana, *hry rand, *Vichigan,

*Mississippi, *Missouri, *New Jcrsuy, *Ohio, *Pennsy Ivania,

*S juti Carolina, *Virginia, *West Virginia and *Wiscunsin

Leafspot caused by Septoria podophyllina Pk.

* +Iew York - Chrutkliqua County, June 25. (Chupp)

Prior rcports: Illinois, Indiana, Iowa, *Mississippi, *Ohio,

*Pernsylvani and *West Virginia.

\section{POLYGALA FRUCIFIORA (Fringed Polygala)}

Rust caused by Puccinia polygalae Pazschke

New York - small colony of Polygala in Enfield Gorge, Tompkins

Cuunty, affected July 8. (Chupp).

Prior reports: *Connecticut, *Michigan, *New Hampshire and *New

York.

\section{POLYGONUM AVICULARE. (Knot Grass, Door Weed)}

Duwdery mildew caused by Erysipho polygur $\perp$ DC.

Minnesota - St. Iouis and Hemepin Counties. (Sect. Pl. Path.)

Prior reports: *C Iifornia, *Delaware, *District of Columbia,

*Ilinois, *Indiana, *Iowa, Minres sta, *Montana, *Nebraska,

*Iicw Mexico, *New York, *North Dakota, *Ohio, *Oregon, *South

Dikota, *Texas, *Vermont, Virginia, * Tashington, *Wisc onsin

and *Wyuming.

Rust caused by Puncinia polyguni Pers.

+New Jersey - New Brunswich, liidulesex County, iugust 28. (Dept.

Pl. Path.) Prior roport; liew Jersey •

+Powdery mildew caused by Sphner,thece sp.

liew Jersey - New Brunswick, Midalesex Courty. (Dept. Pl. Path.)

Rust caused by Uromyces pulygoni (Pers.) Tokl.

*+ivew York - Tompkins Cuunty, lay 27. (Chupp)

Frior reports: *California, *Delaware, *Illinois, *Indiana

*Iowá, *Kunsas, *Maine, *Massachusetts, *Michigan, *Mirne-

suta, *Mississippi, *Missuuri, *Nebraska, *New Hempshire,

*Ncw Jersey, *North Dakuta, *Pennsylvania, *Rhode Is land,

*Suuth Dikota, *Utah, *Vemont, *Washineton and *Wisconsin. 
POLYGONUM ERECTUM (Ertet Knotweed)

+ Ieafspot caused by Gercosnora aviculoris Wint.

Minnesota - Rice Cunty. (Sect. Fl. Path.)

Powdery mildew cau sed by Erysiphe polygoni DC.

*+New York - Tumpkins County, hugust 31. Collected by R. S. Kirby.

(Dept. Pl. Path.)

Prior reports: *Colorado, *Idaho, *Illinois," *Indiana, Iowa, *Minnes ota, North Jakota and *Ohio.

POLYGONUM HYDROPIPER - See Persicaria hydropiper

POLYGOHUM LAPATIIFOLIUM - See Persicaria lapathifolia

POLYGONUM PIINSSY LViNICUM - See Persicaria pennsylvanica

POLYGONUA PARSICARIA -- See Persicaria persicaria

POLYGONUM SP.

Leafspot caused by Cercuspora hydropiporis (Thuem.) Speg.

* +New York - Tompkins County, fugust 5.-(Chupp)

Prior reports: *Illinıis, *Indiana, *Miss uri, *Nebraska, *New Jersey, *Ohio and *Virginia.

+Dudder - Cuscuta gronoji ivilld.

New York - Or leans Courty, Iune 27. (Chupp)

+Powdery mildew caused by Erysiphe sp.

Missuri - Sedalia, pettis Cunty. (Burrill)

Leafspot cau sed by Septuria polygonorum Desm.

ITew York - Tompins County, June 21. (Chupp)

Priur report: *ilest Virginia.

PORTULACA OLERACEA

White rust caused by Aloug o portulacae (DC.) Kuntze

*+New York - Genesse County, July 5. (Chupp)

Prior reports: Alabara, *District of Columbia, *Illinois, *Indiana, *Iowa, *Kansas.; *Naryland, *Massachusetts, Minnes ta, *Mississippi, Missouri, *Montana, *Nebraska, *New Jersey, *North Dakota, *Onio, *South Carolina, *South Dakota and *Texas.

POTENTILIH CHIADENS IS (Common Cinquefoil)

+Magnüsilla potentillae (Farl.) Sadeb.

*iJew York - Tumpkins cunty, July 1. Collected bý M. F. Barrus. (Chupp)

+Rust caused by Pinragmidium potentillae (Pers.) Karst.

*New York - Ithace, Tompkins County, May 8. Collected by H. H. Thetzel. (Dupt. Pl. Path.)

POTENTILIA FISSA

+Magnusiella putentillae (Farl.) Sadeb.

*Colorado - Boulder Falls, Buulder Canyon, Boulder, Boulder County, hugust 5. Collected by Guy West Wilsor. (Jenkins)

POTENTILIA PALUSTRUS - See Comarum palustre

POTENTILLA SP.

Rust caused by Phragmidium potentillae (Pers.) Kurst.

+ New York - Tompkins County, May 6. (Chupp) 
Prior reports: *Coloraç, *Ge orgia, *Maine, *Maryland, Minnesota, *Nontana, *Nebraska, *Nevada, *North Dakota, *South Dakota,

*Vermont, *Washing tun and *Wyoming.

+Rust caused by Fuscinia potentillac Pers.

*New York - Ulster County, May 17. Collected by M. F. Barrus. ( Chupp)

PRENANTHES FIBA - See Nabalus albus

PRENANTHES ALTISSIMA - See Nabalus altissimus

PRIMULA POLYAITHA (Polyanthus Primrose)

+Leafspot caused by Ramularia primulae Thuem.

New York - in University Perennial Garden, Tompkins County, August 25. (Chupp)

PRUNELLA VULGARIS

Leafspot caused by Septoria prunellae Ell. \& Holw.

+New York - Wy oming County, August 24. (Chupp)

Prior report: *Ali bama.

PTERIDIUM AQUILIIUM

Rust caused by Uredinopsis pteridis Diot. \& Holw.

Kontucky - (McFarland)

Recent literature:

MoFraland, F. T. The occurrence of two fern rusts in Kentucky. Science 58: 186. Sept. 1923.

RAIUNCULUS ABORTIVUS (Small Flowered Crowfoot)

Powdery mildew caused by Erysiphe polygoni DC.

* +New York - statewide; Onondaga County, July 19. (Chupp)

Prior reports: *Illinois, *Indiana, Iowa, *Maryland, *Mississippi, *ivorth Dakota and *iisconsin.

+Downy mildew caused by Peronospora ficariae Tul.

New York - statewide; Tompkins County, May 5. (Chupp)

RANUNCULUS ACRIS (Tall Buttercup)

Powdery mildew caused by Erysiphe polygori DC.

* +New York - Onondaga Cunty, July 19; statewide. (Chupp)

Prior reports: *District of Columbia, *Wassachusetts, *Michigan, Minnesota, *New Jersey and *Vermont.

Downy mildew ciused by peronospora ficariae. Tul.

* +iver York - Ithaca, Tomjkins County, May 5. Collected by M. F. Barrus. (Dept. Pl. Path.). Prior renort: *Massachusetts.

RiNUNCULUS HISPIDUS (Bristly Buttercup)

+Downy mildew caused by Peronosnore ficarise Tul.

New York - Ithace, Tompkins County, lay 17. Collected by H. H. Whetzel. (Dept. Pl. Path.)

RANUNCULUS RECURVATUS (Hooked Crovfjot)

Downy mildev: caused by Peronospora ficariat Til.

* +iNew York - Ithaca, Tompkins County, Mry 19. Collected by M. F. Barrus. (Dept. PI. Path.) Prior roport: Indiana.

Leafsiet caused by Pimularia ranunculi Pk.

* +1re W York - Tompkins County, Mey 24. Cullected by M. F. Barrus and

F. ฐ. Honey. (Chupp). Prior report: *Vermont. 
RANUNCULUS SEPTENTRIONALIS (Swamp Buttercup)

+Rust caused by Puccinia olematidis (DC.) Lagerh.

New York - Cortlund County, May 19. Collected by H. H. Whetzel. (Chupp)

RIBES ANERICANUM (American Blach Currant)

Rust caused by Puccinia grossulariae (Schum.) Iagh.

Now York - Tompkins County, May. (Chupp)

Prior reports: Connecticut, Indiana, *Nebraska, *New Yurk, *North Dakota and *Wisconsin.

Fowdery mildew caused by Sphaerotheca mors-uvae (Schw.) Berk. \& Curt.

+Minnesota - Nicollet County. (Sect. Pl. Path.)

Prior reports: Iowa, Montana and North Dakota.

+Mosaic - oause unknown

New York - 50\% in one field, Tompkins County, May 6. Collected by F. R. Perry. (Chupp)

RIBES IHCUSTRE (Prickly Currant)

Rust caused by Puccinia parkerae Diet. \& Holw. +British Columbia - Daisy Lake, August 26. (Boyce)

Prior reports: *Oregon and *Washington.

RIBES SANGUINEUM (Red Plowering Currant)

Leafspot caused by Cercospora ribicola Ell. \& Ev.

+Oregon - résulted in negligible injury; Rujada, Lane County, June 17. (Boyoe). Prior report: *Washington.

RUBUS HISPIDUS (Swamp Dewberry)

+Orange rust oaused by Gymnoconia interstitialis. (Sch I.) Lagh.

Connecticut - N. Branford, New Haven County, June 1. (Clinton)

Tar spot - cause undetermined

New York - Cortland County, May 19. Colleoted by H. H. Whetzel. (Chupp)

RUBUS PARVIFIORUS (Whiteflowering Raspber ry) (Thimbleberry)

Rust caused by Phragmidium occiaentale firth.

* Oregon - caused insignificant injury to the host; Naldport,

Lincoln County, Ootober 10. (Boyse)

Prior reports: Alaska, *California, *úol orado, *Idaho, Minnesota, ${ }_{*}^{*}$ Montana, New Mexico, *Utah, *Washington, Wiscons in and

Wyoming.

Leafspot oaused by Septoria rubi West.

*+Oregon - resulted in negligible injury to the host; Macleay Park,

Portland, Multnomah County, August 2; Waldport, Iinsoln

County, October 9. (Boyce)

Prior reports: *California, *Colorndo, Iaho and *Washington.

RUBUS SP.

Rust caused by Gymnoconia interstitialis (Schl.) Lagh.

+New York - common all along the Huds on and Long Is land; Ulster and Dutchess Counties. Collected by E. F. Guba May 1 (Guba)

Prior repurta: Alabama, Arizona, Arkansas, Connecticut, De laware, Florida, Iowa, Maine, Mary lend, Massachusetts, Minnesota, Missouri, New Jersey, Tennessee, Texas, Virginia and Washingtion. 
*+New York - oreeping dewberry. (Dept. II. Path.)

*+New York - wild blackberry; Labrador Lake, Cortland County, June 3. Collected by M. F. Barrus. (Dept. Pl. Path.)

RUMEX ACETOSA (Green Sorrel) (Schaff)

+Leafspot caused by Gloeosporium rumicis Ell. \& Ev.

New York - $10 \%$ reduction in yield for state; Nassau County, May 29. (Chupp)

RUMEX CRISPUS (Curled or Narrow Dock)

+Dodder - Cuscuta gronovii Willd.

New York - Cayuga County, September 15. Collected by E. E. Honey. (Chupp)

Leafspot caused by Ramularia sp.

New York - statewide; Monroe County, August 21. (Chupp)

RUNEX SPP.

+Mosaic - cáuse unknown

New York - probably statewide; very common and noticeable; both on broad and narrow leaf dock; Niagara County, June 3. (Chupp)

SAPONARIA OFFICINALIS, (Bouncing Bet)

Leafspot. caused by Nacrospor ium saponariue Pk.

*+New York - Tompkins County, June 16. (Chupp)

Prior reports: Connecticut, Indiana, *Marylánd and Minnesota.

SATUREIA VULGARIS (Savory)

+Rust caused by Puccinia menthae Pers.

*New York - collected on Pine Knoll, Forest Home, Tompkins County, May 9. (Chupp)

SAXIFRAGA PENSS YVHNICA

Rust caused by Puccinia saxifragae Schl.

+ New York - on $50 \%$ of plants in one gorge, Tompkins County, May 13. Collected by E. E. Honey. (Chupp)

Prior reports: Indiana and Minnesota.

SAXIFRAGA VIRGINIENSIS

Rust caused by Puccinia saxifragae Sohl.

* New York - on 50\% of plants in one gorge, Tompkins County, May 13. Collected by M. F. Barrus. (Chupp)

Prior report: *District of Columbia.

SCABIOSA JAPONICA (Japanese Scabiosa)

+Stem canker caused by Sclerotinia sclerotiorum (Lib.) Mass.

New York - in University perennial garden; canker on main stem and lower laterul branches; Tompkins County, October 2. collected by Honey and thetzel. (Chupp)

SEDUM SP. (Stonecrop)

+ Leafspot caused by Septoria sedi ilest.

New York - common on plants in florioulturel plots; Tompkins

County, September 6. Collected by E. F. Guba. (Chupp) 
SICYOS ANGULATUS (One-Seeded Bur-(iuoumber)

Downy mildew caused by Rhysotheca australis (Speg.) iils.

+Missouri - collected at Columbia, Boone cunty. (Maneval)

Prior" report: Indiana:

\section{SIDA SPINOSA (Prickly 3ida)}

Rust caused by Puccinia heterospora Berk. \& Curt.

*+Missisșipi - general; Oktibbeha County, September 15... Neal \& Barkerl. Prior reports: ílabama, Florida and Missuri.

SISYMBRIUM OFFICINALF (Heäge Mustard)

White rust caused by hlbugo candida (Pers.) Kuntze

*+New York - Medina, Orleans County, July 11. (Chupp)

Prior reports: *Delaware, *Idaho, Indiana, *Iowa, Minnesota; *New Jersey, *Penns:ylvania, *Washington and West Virginia..

SMILACINA RACBMOSA (False Solomonseal)

+ Leafspot caused by Macrosporium sp.

New York - Monr je County, September 21. Collected by Kirby and Honey. (Chupp)

Leafspot ctused by Phyllosticta convallariae Pers. (Phyllosticta cruenta Kickx.)

* +New York - very commón, Tompkins County, July 4. (Chupp)

Prior reports: Alabama, *Connecticut, Idaho, Indiana, Iuwa, *Maryland, *Massciohusetts, New Jersey, Pennsylvania, *Virginia and Wisconsin.

SMI LLXX SP.

+Fly speck - cause undetermined

New York - Onondága County, May 19. (Chupp)

SOLAIUM DUICAMARA (Bitter Nightshade)

+Dodder - Cuscuta gronovii Willd.

New York - Geriesee County, June 27. (Chupp)

SOLANUM SP. (Nightshade)

+Leafspot caused by Ceroospora atro-margir: Iis Atk.

Florida - observed on the host in waste places; very destructive to the leaves but of no economic conséquenoe." (Weber)

SOLIDAGO ALTISSIMA (TaII GoIdenrod)

Rust caused by Coleosporium solidaginis Thuem.

+New York: - s'tatewide; Monr se County, May.30. (Chupp)

Prior report: Indiana.

+Dodder - Cuscuta gronovii Willd.

New York - Genesee County, June $2 \%$. (Chupp)

+powdery mildew oaused by Erysinhe cich vacamim. DC.

New York - statewide; Tompkins County, August 18. (Chupp)

+Rust caused by purcinia caricis-solidasinis. Arth.

New York - statewide; Onondaga County, June 3. (Chupp)

SOLTDAGO CANADENSIS (Canada Golden rod)

+Rust caused by puccinia caricis-solidaginis irti.

New York - statewide; Onondaca County, June 3. (Chupp) 
SOLIDAGO JUNCEA (Sharptoothed Goldenrod)

+Powdery mildew caused by Erysiphe cichoracearum DC.

New York - statewide; Tompkins County, August $1 \delta$. (Chupp)

SOLIDAGO IATIFOLIA (Broadleaf Goldenrod)

Rust caused by Coleosporium solidaginis Thuem.

+New York - probably statewide; Monroe County, May 30. (Chupp)

Prior reports: Illinois, Indiana, Iowa, Pennsylvania and Texas.

Powdery mildew caused by Erysiphe cichoracearum DC.

+New York - statewide; Tompkins County, August 18. (Chupp)

Prior report: Indiana.

SOLIDAGO PATULA (Roughleaf G.Jidenrod)

+ Rust caused by Puccinia caricis-solidaginis Arth.

*New York - statewide; Onondaga County, June 3. Collected by M. F. Barrus. (Chupp)

SOLIDAGO RUGOSA (Wrinkled Goldenrod)

Rust caused by Coleosporium solidaginis Thuem.

+New York - probably statewide; Monroe Cunty, May 30. (Chupp)

Prior reports: Alabama, Connecticut, *District" of Columbia,

Indiana, Maine, Vermont and West Virginia.

+Rust caused by Puccinia caricis-solidaginis Arth.

*New York - statewide, On ondaga County, June 3. (Chupp)

+ Leafspot caused by Septoria sp.

New York - Onondaga Cunty, June 3. Collected by M. F. Barrus. (Chupp)

SOLIDAGO SEMPERVIRENS (Seaside Guldenrod)

+Rust caused by Puccinia caricis-solidaginis Arth.

New York - statewide; Onondaga County, June 3. (Chupp)

SOLIDAGO SEROTINA (November Goldenrod)

+Fly speck - cause undetermined

New York - Taughannock Falls, Tompkins County, August 18. (Chupp)

SOLIDAGO SPP. (GoIdenrod)

Rust caused by Coleosporium solidaginis Thuem.

+New York - statewide; Monn oe County, May 30. (Chupp)

Prior reports: *Alabama, *Arkansas, *Colorado, *Delaware, *District of Columbia, *Illinois, *Indiana, *Iowa, *Kansas, *Kentucky, *Maine, *Maryland, *Massachusetts, **'ichigan, *Minnesota, *Mississippi, *Missuuri, *Montena, *Nebraska, *New Hampshire, *New Jersey, *New York, *North Carolina, *North Dakuta, *Ohio, *Oklahama, *Oregon, *Penris yirania, *S Juth Carulina, *South Dakuta, *Tennessee, *Virginia, *Washington and *Wișcons in.

+Dodder - Cuscuta gronovii Willd.

New York - Genesee County, June. 27. (Chupp)

Powdery mildew caused by Erysiphe cichorucearun DC.

+New York - statewide; Tompkins County, August 18. (Chupp)

Prior report: Montana.

+Black knot caused by Montagnella helinpsidis (Schw.) Sacc.

llew York - common; Tumpkins County, May 7. Collected by $H$ M. Fitzpatrick. (Chupp)

+ Leafspot caused by Rhytisma punctatum (Pers.) Fr.

New Jcr'sey - New Brunswick, Middlesex Cunty, September. (Dept. Pl. Path.) 
Mosaic - cause undetermined

*New York - Nassau County, June 10... Collected by Mills and Whetzel. (Chupp)

STACHYS CILIATA (Hedge Nettle).

+Powdery mildew caused by Erysiphe galeopsidis DC.

Washington - Beaver, Clallam County, August 14. (Boyce)

STACHYS mINUIFOLIA (Smooth Hedge Nettle)

+Pawdery mildew caused by Erysiphe galeopsidis DC.

New York - Onondaga County, September 15. Collected by E. E. Honey. (Chupp)

+Leafsoot caused by Septoria stachydis Rob. \& Desm.

New York - Tompkins County, September 11. Cullected by Kirby and

H дney. (chupp)

STELIHRIA MEDIA - See flsine media

SMPIOCARPUS FOETIDUS (Skunk Cabjage)

+ Rot caused by Botrytis sp.

New York - Nasscu C unty, June 9. (Chupp)

TARAXACUM DENS-IFONIS - See Taraxacum officinale

TARAXACUM ERY THROSPERMUM : (Dandelion)

+Rust caused by Puccinia taraxaci (Reb.) Plow:

*New York - collected by R. S. Kirby, September 9. (Dept. Pl. Path.)

TARAXI:CUM OF FICINALF, (Common Dandelion)

Rus't caused by Puccinia taraxaci (Reb.) PIJw.

Prior reports: *Colorado, Connecticut, *Ilaho, Illinois, *Indiana, Iowa, *Kansas, * Kentucky, *Loulis iana, *Ma ine, *Mary lanả, * Michigan, Minnesjta, *Missouri, *Mortana, *Nebraska, *New

Jersey, *New York, *North.Dakuta, *Ohi ,, *Penns ylvania, *S juth

Dakota, *Utah, *Vermont, *Washington, West Virginia,* *Wiscons in and. *Wy oring.

Leafspot caused by. Ramularia Iinejla Pk.

*+New York - Orleans Cunty, June 11. (Chupp)

Prior reports: Indiana and *North Dakota.

Leafspot caused by Ramularia taraxici Karst.

Minnesota - Waseca County..(Dept. PI. Path.)

Prior reports: *Colorado, Connecticut, Idaho, *Illinois, Iowa, *Mississippi and *North Dakota.

Fowdery mildew caused by Sphaerotheca caistignei Lev.

+Connecticut - Storrs, Faglevilie cjunty, iugust 3. (clinton)

Prior reports: Illinois, Miss juri, iNew York and North Dakota.

Powdery mildew caused: by: Sohatrotheca huriuli (DC.) Burr.

*+New York - stiatewide; Tomplins Cunty, July 2. (Chupp)

Prior reports: Connecticut; IĆaho, *Illinois, *Indian丸, Iowa,

*Kansas, *Massachusetts, Minnesjta, *Missuri, *North Dakota,

Ohio and Washington.

Stem and leaf nematode caused by Tylenchus dipsaci (Ruehn) Bast. Report by G. H. Godfrey, JuIy 24,1923

"During the course of the Fifth Annual Field Meeting

of Phytopathologists, held July 9-12, in western New York, 
the stem nematode (Tvlenohus dipsroi) was found in sume abundance infesting the dandelion, iaraxsum officinale. "The symptoms were typical of thuse pruciuced by the same organism on other hosts, -- a thickening and crinkling of the leaf in spots, or, in the severer cases in large regions, resulting in marked distortion. Usually a spot could be discerned by its lighter green color, but the very characteristic finely netted crinkling is the distinguishing feature. This is most readily seen as a rule on the lower loaf surface. Often a midrib or one of the branch veins is attacked and shows a swelling and a distortion of the leaf at this point. Sometimes the mesophyll tissue alone is attacked.

"This finding is not especially significant in itself, but indicates the possible occurrence on other hosts, and a possible gradual adaptation which may result in a real problem in American agriculture.

"This constitutes the first finding of Tylenchus dipsaci in the Northeast, aside from its occasional occurrence in Narcissus bulbs imported from Europe. It was found to be widespread. Infected plants were found at Ithaca, Williamson, Medina and Rochester, New York, and even at Vineland and other points in the Province of Ontario, Canada. It was not found on a brief survey in a park in North Philadelphia or at Washington, D. C."

THALICTRUM POLYGAMUM ( Tall Meadow Rue)

Rust caused by Puccinia thalictri Chev.

*+New York - Onondaga County, June 30. Collected by H. H. Whetzel. (Dept. PI. Path.)

Prior reports: *Massachusetts, *New Hampshire and *Pennsylvania.

TINIARIA CONVOLVULUS. (Corn Bindweed)

Rust caused by Puccinia polygoni-amphibii Pers.

* +New York - Tompkins County, August 11. (Chupp)

Prior reports: Indiana and Minnesota.

TINIARIh SCANDENS (Climbing False Buckwheat)

Downy mildew caused by Peronospora polygon: Thuem.

+New York - Tompkins County, June 23. (Chupp)

Prior report: Iowa.

Rust caused by Puccinia polvgoni-amphibii Pers.

New York - Tompkins County, August 71. (Chupp)

Prior report: *Illinois.

TRIADENTM VIRGINICUN! (Narch St. Johnswort)

+Rust caused by Uromyces hyoerice-frondosi (Schw.) Arth.

* New York - Sag Harbor, Suffolk County, June 21. Collected by M. F. Barrus. (Dept. Pl. Path.)

TRIFOLIUM HYBRIDUM 2047

+Leafspot caused by Cercospora zebrina Pass.

*Indiara - Lafayette, Tippecanoe County, September 4. Collected by

E. B. Mains. (Mains) 
TRIILIUM GRANDIF IORUM (Snow .Trillium)

+ Rust caused by Aecidium trilii-i Burr.

New York - Tompkins County, May 24. (Chupr)

URTICA DIOICA (Stinging Nettle)

+Rust caused by Puccinia unticae (Schum.) Lagh.

Minresota - Waseça County. (Dept. PI. Path.)

URTICASTRUM DIVARICATUM (Wood Nettle (Laportea janadens is)

+Doduer - Cuscuta gr onovii Willd.

New York - Onondaga county, September 15. (Chupp)

+ Powdery mildew caused by Erysiphe cichoracearum D.C.

New York - Monroe County, September 22. (Chupp)

VACCINIUM CANÁDENSE (Canada Blueberry)

Rust caused by Calyptospora colurmaris ( $H 1 b$. \& Schw.) Kuhn.

+Minnes ota - Itasca County. (Sect. PI. Path.).

Prior reports: California, Coloradj, Idaho, Maine, Massachusetts, Vermont and Washington.

VACCINIUM OVATUM (Huckleherry, Evergreen)

+ Ieaf rust caused by Pucciniastrum mirtili (Schum.) Arth.

British Columbia - not c ommon, Daisy Lake, rugust 22. (Boyce)

VACC INIUM PENNSYLVANIC UM

Rust caused by Calyptospora columnaris (Alb. \& Schw.) Kuhn.

+Minnesota - Itasca County. (Sect: PI. Path.)

Prior reports: Maine and Wassachusetts.

VACCINIUM VITISIDAEA (Cowberry)

Ieafspot caused by Exobasidium vaccinii (Fokl.) wor.

*+New Y ork - Nassau County, June 9.. Collected by W. D. Mills.

(Dept. PI. Path.). Prior report: Alciska.

VERATRUM VIRIDE (American False Heliebore)

Rust caused by puccinia veratri Niessl.

*+New York - Tumpkins County, 4ugust 1... Collected by E. E. Honey.

(Chupp)

Prior reports: *California; *New Hampshire and *West Virginia.

VERBíSCUM BLítTARIA (Moth Mullen)

Leafspot caused by Septuria verbascicola Berk. \& Curt. .

* +New York - Niagara County, June 26. Collected by E. E. Honey.

(Chupp)

Prior reports:" Alabama, Indiana, *Kentucliy, *New Jersey, *Ohio and *Penns ylvania

VERBENA SP. (Vervain)

Powdery mildew caused by Erysiphe oichoracearum DC.

*+New York - Onondaga County, September 3. Collected by K. H. Fernow.

(Dept. Pl. Path.)

Prior reports: *Alabama, *District of Columbia, *Illinois,

*Luisiana, *Minnesota, Mississippi, *New Mexico, *Texas and

* ilisconsin. 
446

VIOLA CANADEINSIS (Caneda Violot)

Rust causod by Puscinia viogac (Schum.) DC.

* New York - Highland, Ulster Cunty, May 17. Collected by M. F. Barrus. (Dept. PI. Path.)

Frior reports: Indiana and North Dakota.

VIOLA PUBESCENS (Downy Yellow Violet).

Rust caused by Puocinia violac (Schum.) DC.

*+Iowa - Mont Jur, Tama Cuunty, Nay 30. Collected by H. S. Conard. (Dept. Pl. Path.). Prior report: Indiana.

VIOLA STRIATA (Cream Violet)

Rust caused by puccinia violae (Schum.) DC.

*+New York - Ithaca, Tompkins County, May 20. Cullected by M. F. Barrus. (Dept. Pl. Path.). Prior report: Indiana.

VITIS CORDIFOLIh (Frost Grape)

Downy rnildew caused by Plasmopara viticula (Berk. \& Curt.) Berl. \& deT.

* New York - Ithaca, Tompkins. County, July I. Collected by M. F. Barrus. (Dept. Pl. Path.)

Prior reports: *Indiana, *Maryland, *Missouri and *Ohio.

VITIS SP. ( (Hild Grape.)

+ Leafspot caused by Macrophoma sp.

New York - Tompkins Cunty, September 8. (Chupp)

WAIDSTEINIA FRAGARIOIDES. (Barren Strawberry)

+Rust caused by Puccinia waldsteiniae Curt.

New York - Tompkins County, July 4. (Chupp)

Leafsp.t caused by Septoria waldsteiniae Pk. \& Cke.

New York - Tompkins Cunty, Oct jber 5.: Collected by R. S. Kirby. (Chupp)

XANTHIUM COMMUNE

Rust caused by Puccinia xanthii Schw.

* Minnesota - Her on Lake, Jackson County, July 25. Collected by

H. S. Conard. (Dept. Pl. Path.) Prior report: Indiana.

XANTHIUM: ORIENTILE (Cocklebur)

Rust caused by Fuccinia xanthii Schw.

*+New York - Trnpkins County, May 24. (Chupp)

Oklahoma - Payne Cunty, Septemier 18. (Stratton)

+Coloredo - F.t. Collins, Larimer County, July. (Learn)

+New Jursey - Medford, Burlington Cuntj, September 5. (Dept. Pl. Path.).

Prior reports: Alabama, Indiana, Mississippi, North Dakota and *oklah uma. 